\title{
ERRATA SHEET
}

The Following Corrections and Clarifications Apply to: Corrective Action Decision Document/Closure Report for Corrective Action Unit 552: Area 12 Muckpile and Ponds, Nevada Test Site, Nevada.

DOE Document Number: DOE/NV-1073

Revision: 0

Original Document Issuance Date: September 2005

This errata sheet was issued under cover letter from DOE on: December 21, 2005

The signature is omitted from the CAU Use Restriction Information form on page F-1 of F-2. Replace with the attached signed form. 


\section{CAU Use Restriction Information}

CAU NumberiDescription: CAU 552. Area 12 Muckpile and Ponds

Applicable CAS Number(s)/Description(s): CAS 12-23-05. Ponds

Contact (organization/project): NNSANSO Industrial Sites Project Manager

Surveyed Area (UTM, Zone 11, NAD 27, meters):

Southwest Corner: $N=4113679.689 ; \quad E=571846.151$

Southeast Corner: $N=4113651.911 ; E=571956.183$

Northwest Corner: $N=4113707.287 ; \quad E=571861.946$

Northeast Corner: $N=4113697.237 ; \quad E=571958.191$

Survey Date: June 2005

Survey Method (GPS, etc): GPS

Site Monitoring Requirements: Inspection of fencing and postings

Required Frequency (quarterly, annually?): Annual

If Monitoring Has Started, Indicate last Completion Date: Nol Applicable

\section{Use Restrictions}

The future use of any land related to this Corrective Action Unit (CAU), as described by the above surveyed location, is restricted from any DOE or Air Force activity that may alter or modify the containment control as approved by the state and identified in the CAU Closure Report or other CAU 552 documentation, unless appropriate concurrence is obtained in advance.

Comments: The upper pond may be released after the closure of the G-Tunnel muckpile. The use restriction implemented by this document may be revoked following a future corrective action that may eliminate the need for a use restriction at this site. See the Corrective Action Decision. Document/closure Report for additional information on the condition of the site and any monitoring and/or inspection requirements.

Submitted By:

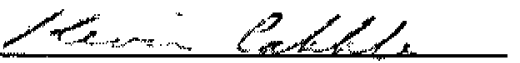

Date: $\angle \not-\angle>-Q 5$

cc with copy of survey map (paper and digital (.dgn) formats):

CAU Files (2 copies) 
Nevada

Environmental

Restoration

Project

\section{Corrective Action Decision Document/ Closure Report for Corrective Action Unit 552: Area 12 Muckpile and Ponds Nevada Test Site, Nevada}

Controlled Copy No::

Revision No.: 0

September 2005

Approved for public release; further dissemination unlimited.

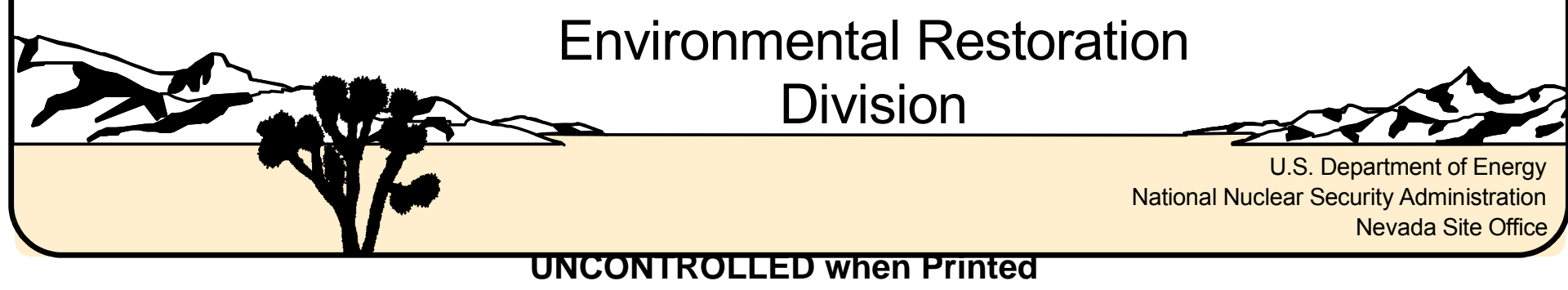


Available for public sale, in paper, from:

U.S. Department of Commerce

National Technical Information Service

5285 Port Royal Road

Springfield, VA 22161

Phone: 800.553 .6847

Fax: 703.605.6900

Email: orders@ntis.gov

Online ordering: http://www.ntis.gov/ordering.htm

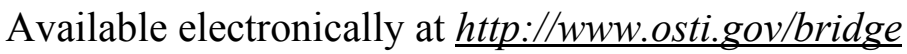

Available for a processing fee to U.S. Department of Energy and its contractors, in paper, from:

\section{U.S. Department of Energy}

Office of Scientific and Technical Information

P.O. Box 62

Oak Ridge, TN 37831-0062

Phone: 865.576 .8401

Fax: 865.576.5728

Email: reports@adonis.osti.gov

Reference herein to any specific commercial product, process, or service by trade name, trademark, manufacturer, or otherwise, does not necessarily constitute or imply its endorsement, recommendation, or favoring by the United States Government or any agency thereof or its contractors or subcontractors. 


\title{
CORRECTIVE ACTION DECISION DOCUMENT/ CLOSURE REPORT FOR CORRECTIVE ACTION UNIT 552: AREA 12 MUCKPILE AND PONDS NEVADA TEST SITE, NEVADA
}

\author{
U.S. Department of Energy \\ National Nuclear Security Administration \\ Nevada Site Office \\ Las Vegas, Nevada
}

Controlled Copy No.:

Revision No.: 0

September 2005

Approved for public release; further dissemination unlimited. 


\title{
CORRECTIVE ACTION DECISION DOCUMENT/CLOSURE REPORT FOR \\ CORRECTIVE ACTION UNIT 552: \\ AREA 12 MUCKPILE AND PONDS \\ NEVADA TEST SITE, NEVADA
}

\author{
Approved by: \\ APPROVED SIGNATURE \\ Date: $08 / 29 / 2005$ \\ Sabine Curtis, Acting Project Manager \\ Industrial Sites Project
}
Approved by: APPROVED SIGNATURE
Janet Appenzeller-Wing, Acting Division Director
Environmental Restoration Division

Date: 


\section{Table of Contents}

List of Figures. . . . . . . . . . . . . . . . . . . . . . . .

List of Tables. . . . . . . . . . . . . . . . . . . . . . . .

List of Acronyms and Abbreviations $\ldots \ldots \ldots \ldots \ldots \ldots \ldots \ldots \ldots \ldots \ldots \ldots \ldots \ldots \ldots$

Executive Summary . . . . . . . . . . . . . . . . . . . . . . . . . . ES-1

$1.0 \quad$ Introduction. . . . . . . . . . . . . . . . . . . . . . . . . . 1

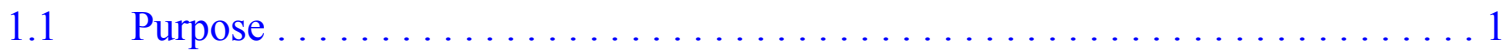

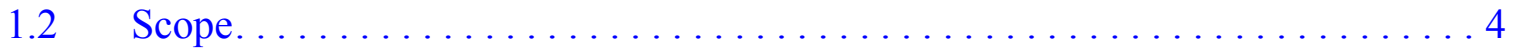

1.3 Corrective Action Decision Document/Closure Report Contents . . . . . . . . . 4

1.3.1 Applicable Programmatic Plans and Documents . . . . . . . . . . . . 5

1.3.2 Data Quality Assessment Summary .................. 6

2.0 Corrective Action Investigation Summary $\ldots \ldots \ldots \ldots \ldots \ldots \ldots \ldots \ldots \ldots$

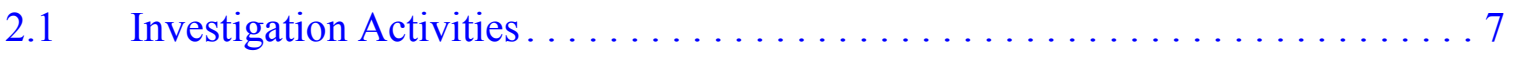

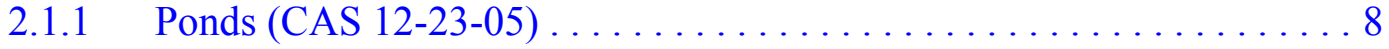

2.1.1.1 Land Area Radiological Walkover Survey . . . . . . . . 8

2.1.1.2 Geophysical Walkover Survey .............. 9

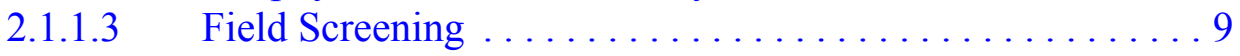

2.1.1.4 Intrusive Investigation $\ldots \ldots \ldots \ldots \ldots \ldots \ldots$

2.1.1.5 Waste Characterization ................... 10

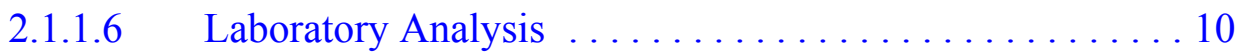

2.1.1.7 Conceptual Site Model Validation . . . . . . . . . . 10

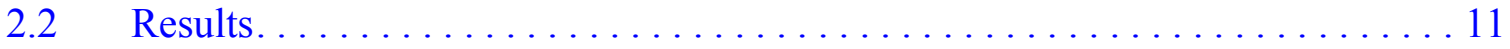

2.2.1 Summary of Analytical Data . . . . . . . . . . . . . . 11

2.2.2 Data Assessment Summary . . . . . . . . . . . . . . . . . . . . . 12

2.3 Justification for No Further Action. . . . . . . . . . . . . . . . . 12

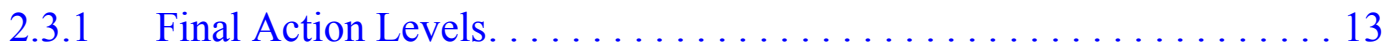

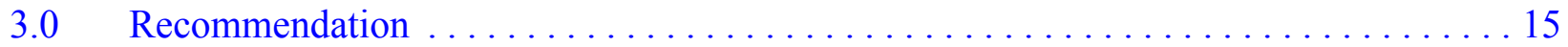

$4.0 \quad$ References.................................... 16

Appendix A - Corrective Action Investigation Results for CAU 552

A.1.0 Introduction. . . . . . . . . . . . . .

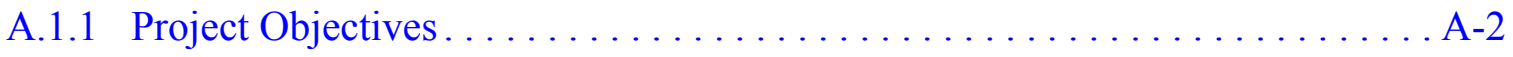

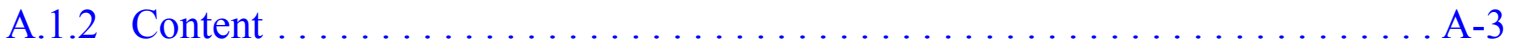

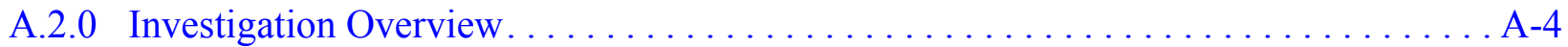

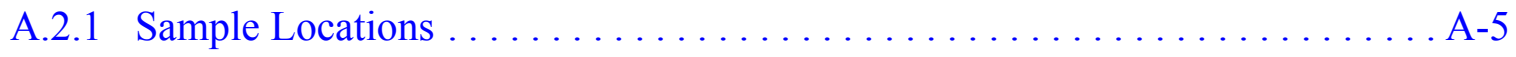

A.2.2 Investigation Activities . . . . . . . . . . . . . . . . . 


\section{Table of Contents (Continued)}

A.2.2.1 Surface Radiological Surveys....................... A-6

A.2.2.2 Site Walkovers ............................ A-6

A.2.2.3 Field Screening ........................... A

A.2.2.4 Surface and Subsurface Sampling $\ldots \ldots \ldots \ldots \ldots \ldots \ldots \ldots \ldots$ A-7

A.2.2.4.1 Waste Characterization and Sampling ........... A-13

A.2.2.4.2 Sample Location Documentation ................ A-13

A.2.3 Laboratory Analytical Information........................ A-14

A.2.4 Comparison to Action Levels . . . . . . . . . . . . . . . . . . . . . . A-15

A.2.5 Geology ..................................... 15

A.2.6 Hydrology ....................................... A-16

A.2.7 Deviations . . . . . . . . . . . . . . . . . . . . . . . . . . . . A-16

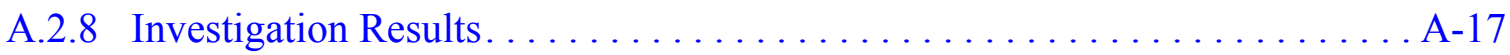

A.2.8.1 Total Volatile Organic Compounds ..................... A-17

A.2.8.2 Total Semivolatile Organic Compounds .................. A-17

A.2.8.3 Total Metals and Beryllium ...................... A-17

A.2.8.4 Polychlorinated Biphenyls . . . . . . . . . . . . . . . . . . A-17

A.2.8.5 Total Petroleum Hydrocarbons. . . . . . . . . . . . . . . . A-17

A.2.8.6 Gamma-Emitting Radionuclides $\ldots \ldots \ldots \ldots \ldots \ldots \ldots \ldots \ldots \ldots . \ldots \ldots$

A.2.8.7 Specific Isotopic Analysis . . . . . . . . . . . . . . . . . . A-19

A.2.9 Nature and Extent of Contamination $\ldots \ldots \ldots \ldots \ldots \ldots \ldots \ldots \ldots \ldots$ A -19

A.2.10 Revised Conceptual Site Model .......................... A-19

A.3.0 Waste Management. ................................ A-33

A.3.1 Characterization ............................... A-33

A.3.2 Waste Streams................................ A-33

A.3.3 Investigation-Derived Waste Generated.................... A-34

A.3.4 Waste Characterization Samples ....................... A-34

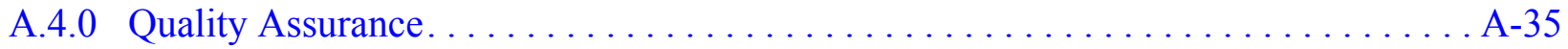

A.4.1 Data Validation.................................... A

A.4.1.1 Tier I Evaluation. . . . . . . . . . . . . . . . . . . . . .

A.4.1.2 Tier II Evaluation . . . . . . . . . . . . . . . . . . . . .

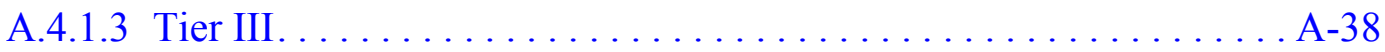

A.4.2 Quality Control Samples.......................... A-38

A.4.2.1 Field Quality Control Samples ................... A-38

A.4.2.2 Laboratory Quality Control Samples ................. A-39

A.4.3 Field Nonconformances ............................ A-39

A.4.4 Laboratory Nonconformances $\ldots \ldots \ldots \ldots \ldots \ldots \ldots \ldots \ldots \ldots \ldots \ldots \ldots \ldots$

A.5.0 References. . . . . . . . . . . . . . . . . . . . . . . . . . . . . . . . . . . . . . A -40 


\section{Table of Contents (Continued)}

\section{Appendix B - Data Assessment for CAU 552}

B.1.0 Data Assessment. . . . . . . . . . . . . . . . . . . . . . . . . B-1

B.1.1 Review DQOs and Sampling Design . . . . . . . . . . . . . . . B-2

B.1.1.1 Decision I Decision Rules . . . . . . . . . . . . . . . . . . B-2

B.1.1.1.1 DQO Provisions to Limit False

Negative Decision Error ................. B-3

B.1.1.1.2 DQO Provisions to Limit False

Positive Decision Error . . . . . . . . . . . . . . . . B-8

B.1.1.2 Decision II Decision Rules . . . . . . . . . . . . . . . . . . . B-9

B.1.1.2.1 DQO Provisions to Limit False

Negative Decision Error . . . . . . . . . . . . . . . . . B-9

B.1.1.2.2 DQO Provisions to Limit False

Positive Decision Error ................ B-10

B.1.2 Conduct a Preliminary Data Review . . . . . . . . . . . . . . . . . B-10

B.1.3 Select the Test and Identify Key Assumptions. . . . . . . . . . . . . . . B-11

B.1.4 Verify the Assumptions . . . . . . . . . . . . . . . . . . . . B-11

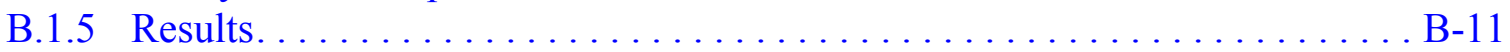

B.1.5.1 Decision I Decision Rules $\ldots \ldots \ldots \ldots \ldots \ldots \ldots \ldots$. . . . . . . .

B.1.5.2 Decision II Decision Rules . . . . . . . . . . . . . . . . B-11

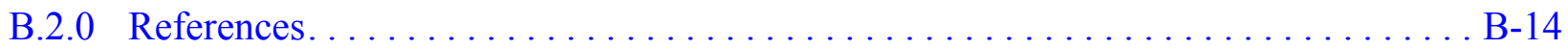

\section{Appendix C - Risk Assessment for CAU 552}

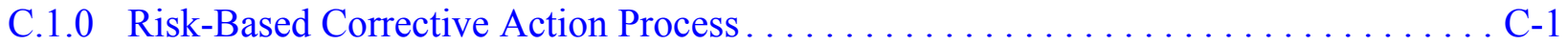

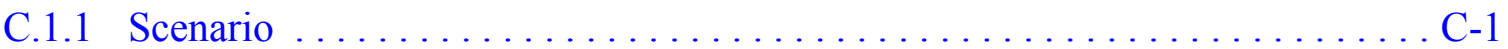

C.1.2 Site Assessment . . . . . . . . . . . . . . . . . . . . C-1

C.1.3 Site Classification and Initial Response Action . . . . . . . . . . . . C-3

C.1.4 Development of Tier 1 Look-Up Table of Risk-Based

Screening Level Selection . . . . . . . . . . . . . . . . . C-3

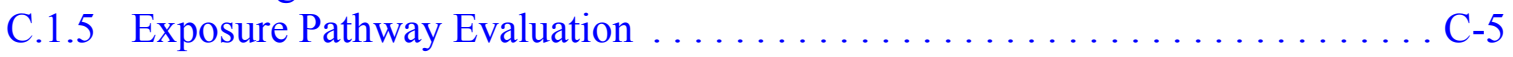

C.1.6 Comparison of Site Conditions with Tier 1 Risk-Based

Screening Levels. . . . . . . . . . . . . . . . . . . . C-6

C.1.7 Evaluation of Tier 1 Results . . . . . . . . . . . . . . . . . . . C-6

C.1.8 Tier 1 Remedial Action Evaluation . . . . . . . . . . . . . . . . C-6

C.1.9 Tier 2 Evaluation . . . . . . . . . . . . . . . . . . . . C-6

C.1.9.1 Development of Tier 2 Table of Site-Specific Target Levels. . . . . . . C-6

C.1.10 Comparison of Site Conditions with Tier 2 Table SSTLs . . . . . . . . . . . C-8

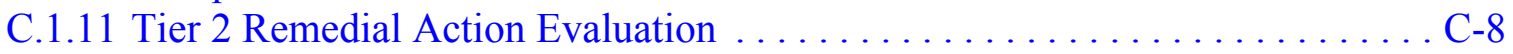




\section{Table of Contents (Continued)}

C.2.0 Regulatory Basis . . . . . . . . . . . . . . . . . . . . . . C-9

C.3.0 References................................... C-10

Appendix D - Closure Activity Summary for CAU 552

D.1.0 Closure Activity Summary . . . . . . . . . . . . . . . . . . . D-1

D.1.1 Use Restriction . . . . . . . . . . . . . . . . . . . . . . . D-1

D.1.2 Removal of Current Site Features. . . . . . . . . . . . . . . . . D-1

D.1.3 Future Site Activities . . . . . . . . . . . . . . . . .

Appendix E - Sample Location Coordinates for CAU 552

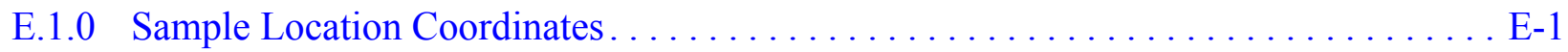

Appendix F - Use Restriction for CAU 552 


\section{List of Figures}

Number

Title

Page

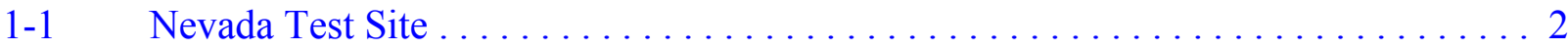

1-2 CAU 552, CAS Location Map $\ldots \ldots \ldots \ldots \ldots \ldots \ldots \ldots \ldots \ldots \ldots \ldots \ldots \ldots \ldots \ldots \ldots$

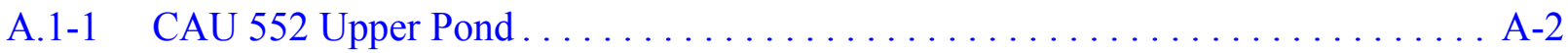

A.2-1 Sample Location Map, CAS 12-23-05, Ponds ................... A-11

A.2-2 Drainage Sample Location Map, CAS 12-23-05, Ponds .............. A-12

C.1-1 ASTM Method E1739-95 Risk-Based Corrective Action Decision Process ...... C-2

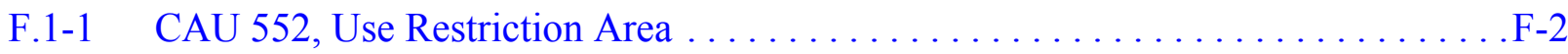




\section{List of Tables}

Number

Title

Page

2-1 Definition of Final Action Levels

A.2-1 Corrective Action Investigation Activities Conducted at

Each Corrective Action Site To Meet Corrective Action Investigation

Plan Requirements

A.2-2 Samples Collected at CAS 12-23-05, Ponds .................. A-8

A.2-3 Laboratory Analytical Parameters and Methods,

CAU 522 Investigation Samples

A.2-4 Soil Sample Results for Total VOCs Detected

Above Minimum Reporting Limits at CAS 12-23-05 .

A.2-5 Soil Sample Results for Metals Detected

Above Minimum Reporting Limits at CAS 12-23-05 . . . . . . . . . . A-20

A.2-6 Soil Sample Results for TPH Detected

Above Minimum Reporting Limits at CAS 12-23-05 . . . . . . . . . . . A-23

A.2-7 Soil Sample Results for Gamma-Emitting Radionuclides Detected

Above Minimum Detectable Concentrations at CAS 12-23-05 . . . . . . . . . . A-24

A.2-8 Soil Sample Results for Specific Isotopes Detected

Above Minimum Detectable Concentrations at CAS 12-23-05. . . . . . . . . . A A-30

B.1-1 Chemical Analytes Failing Sensitivity Criteria . . . . . . . . . . . . B-5

B.1-2 Precision Measurements . . . . . . . . . . . . . . . . . .

B.1-3 Accuracy Measurements $\ldots \ldots \ldots \ldots \ldots \ldots \ldots \ldots \ldots \ldots \ldots \ldots \ldots$

B.1-4 Key Assumptions . . . . . . . . . . . . . . . . . . . .

C.1-1 Maximum Detected Concentrations. . . . . . . . . . . . . . . C-4

C.1-2 Tier 2 SSTLs and CAU 552 Results for Hazardous Constituents of Diesel . . . . C-7

E.1-1 Sample Location Coordinates and Locations of Interest for CAS 12-23-05 . . . . E-1 


\section{List of Acronyms and Abbreviations}

ASTM American Society for Testing and Materials

bgs Below ground surface

CADD Corrective Action Decision Document

CAI Corrective Action Investigation

CAIP Corrective Action Investigation Plan

CAS Corrective Action Site

CAU Corrective Action Unit

CLP Contract Laboratory Program

$\mathrm{cm} \quad$ Centimeter

COC Contaminant of concern

COPC Contaminant of potential concern

CR Closure Report

Cs Cesium

CSM Conceptual site model

DOE U.S. Department of Energy

DQA Data quality assessment

DQI Data quality indicator

DQO Data quality objective

DRO Diesel-range organics

EPA U.S. Environmental Protection Agency

FAL Final action level

FD Field duplicate

FFACO Federal Facility Agreement and Consent Order

FID Flame-ionization detector

FSL Field-screening level

FSR Field-screening result 


\section{List of Acronyms and Abbreviations (Continued)}

\begin{tabular}{|c|c|}
\hline $\mathrm{ft}$ & Foot \\
\hline GPS & Global positioning system \\
\hline GRO & Gasoline-range organics \\
\hline $\mathrm{H} \& \mathrm{~S}$ & Health and safety \\
\hline ID & Identification \\
\hline IDW & Investigation-derived waste \\
\hline LCS & Laboratory control sample \\
\hline $\mathrm{MDC}$ & Minimum detectable concentration \\
\hline $\mathrm{mg} / \mathrm{kg}$ & Milligrams per kilogram \\
\hline $\mathrm{mi}$ & Mile \\
\hline $\mathrm{mrem} / \mathrm{yr}$ & Millirem per year \\
\hline MRL & Minimum reporting limit \\
\hline MS & Matrix spike \\
\hline MSD & Matrix spike duplicate \\
\hline NA & Not applicable \\
\hline NAC & Nevada Administrative Code \\
\hline ND & Normalized difference \\
\hline NDEP & Nevada Division of Environmental Protection \\
\hline NIST & National Institute for Standards and Technology \\
\hline NNSA/NSO & $\begin{array}{l}\text { U.S. Department of Energy, National Nuclear Security Administration } \\
\text { Nevada Site Office }\end{array}$ \\
\hline NTS & Nevada Test Site \\
\hline PAL & Preliminary action level \\
\hline PB & Preparation blank \\
\hline PCB & Polychlorinated biphenyl \\
\hline POC & Performance objective criteria \\
\hline PPE & Personal protective equipment \\
\hline
\end{tabular}




\section{List of Acronyms and Abbreviations (Continued)}

\begin{tabular}{ll} 
ppm & Parts per million \\
PRG & Preliminary Remediation Goal \\
QA & Quality assurance \\
QAPP & Quality Assurance Project Plan \\
QC & Quality control \\
RCRA & Resource Conservation and Recovery Act \\
RMA & Radioactive Material Area \\
ROTC & Record of Technical Change \\
RPD & Relative percent difference \\
SCL & Sample collection log \\
SDG & Sample delivery group \\
SSL & Soil screening level \\
SSTL & Site-specific target level \\
SVOC & Semivolatile organic compound \\
TPH & Total petroleum hydrocarbons \\
VOC & Volatile organic compound \\
WM & Waste management \\
$\mu$ /kg & Micrograms per kilogram \\
RR & Percent recovery \\
\hline
\end{tabular}




\section{Executive Summary}

This Corrective Action Decision Document/Closure Report has been prepared for Corrective Action Unit (CAU) 552, Area 12 Muckpile and Ponds, located in Area 12 at the Nevada Test Site, Nevada, in accordance with the Federal Facility Agreement and Consent Order (1996). Corrective Action Unit 552 is comprised of one corrective action site (CAS):

\section{- CAS 12-23-05, Ponds}

The muckpile was removed from CAU 552 because there is an active leachpit within the muckpile and current activities exist at G-tunnel. The purpose of this Corrective Action Decision Document/Closure Report is to provide justification and documentation supporting the recommendation for closure of CAU 552 with no further corrective action. To achieve this, corrective action investigation (CAI) activities were performed from November 18, 2004 through April 25, 2005, as set forth in the Corrective Action Investigation Plan for Corrective Action Unit 552: Area 12 Muckpile and Ponds, Rev. 1 (NNSA/NSO, 2005) and Records of Technical Change No. 1 and No. 2. The purpose of the CAI was to fulfill the following data needs as defined during the data quality objective process:

- Determine whether contaminants of concern are present.

- If contaminants of concern are present, determine their nature and extent.

- Provide sufficient information and data to complete appropriate corrective actions.

The CAU 552 dataset from the investigation results was evaluated based on the data quality indicator parameters. This evaluation demonstrated the quality and acceptability of the dataset for use in fulfilling the data quality objective data needs. Analytes detected during the CAI were evaluated against the final action levels (FALs) established in this document. It was determined that cesium-137 contamination exists in the surface soils and sediment within the upper pond (the pond closest to the muckpile) at concentrations exceeding the FAL of 7.3 picocuries per gram (up to 189 picocuries per gram).

A Tier 2 FAL was calculated for total petroleum hydrocarbons (TPH)-diesel-range organics (DRO). The Tier 2 FAL for TPH-DRO was established as the U.S. Environmental Agency Region 9 Preliminary Remediation Goal values for the individual hazardous constituents of diesel. The 
evaluation of hazardous constituents of diesel based on the Tier 2 determined that FALs were not exceeded.

Due to the continued presence of the G-Tunnel muckpile as a potential active source of cesium-137 contamination for CAS 12-23-05 in concentrations greater than the FAL, remediation of the surface contamination is deemed unfeasible at this time. Therefore, a use restriction to limit worker exposure to site contaminants was imposed on future site activities. However, the use restricted area of CAU 552 should be reassessed once the CAI of the G-Tunnel muckpile has been completed and the source of contamination is controlled. The U.S. Department of Energy, National Nuclear Security Administration Nevada Site Office provides the following recommendations:

- Closure in place with use restriction.

- No further corrective action for CAU 552

- No Corrective Action Plan.

- A Notice of Completion to the U.S. Department of Energy, National Nuclear Security Administration Nevada Site Office is requested from the Nevada Division of Environmental Protection for closure of CAU 552. This notice should include a provision that the site be re-addressed after the closure of the G-Tunnel muckpile.

- Corrective Action Unit 552 should be moved from Appendix III to Appendix IV of the Federal Facility Agreement and Consent Order. 


\subsection{Introduction}

This Corrective Action Decision Document (CADD)/Closure Report (CR) has been prepared for Corrective Action Unit (CAU) 552, Area 12 Muckpile and Ponds, Nevada Test Site (NTS), Nevada. The corrective actions proposed in this document are in accordance with the Federal Facility Agreement and Consent Order (FFACO) that was agreed to by the State of Nevada, U.S. Department of Energy (DOE), and the U.S. Department of Defense (FFACO, 1996). The NTS is approximately 65 miles (mi) northwest of Las Vegas, Nevada (Figure 1-1).

Corrective Action Unit 552 is comprised of the corrective action site (CAS) that is shown on Figure 1-2 and listed below:

- 12-23-05, Ponds

The ponds were originally constructed to catch runoff from the muckpile. As the muckpile continued to be extended to the north and to the east, it became impossible to ensure that all of the runoff from the muckpile was funnelled into the pond. Some of the runoff from the muckpile continues to be caught in the upper pond, but portions of the muckpile have eroded, diverting much of the runoff away from the ponds. Regarding the other ponds, there is no evidence that any of the overflow ponds ever received runoff from overflow of the upper pond.

The muckpile was removed from CAU 552 because an active leachfield exists within the muckpile and there are current activities at G-Tunnel. A detailed discussion of the history of this CAU is presented in the Corrective Action Investigation Plan (CAIP) for Corrective Action Unit 552: Area 12 Muckpile and Ponds, Nevada Test Site, Nevada, Rev. 1 (NNSA/NSO, 2005).

\subsection{Purpose}

Corrective Action Unit 552, Area 12 Muckpile and Ponds, consists of one site located in the southern portion of Area 12. Corrective Action Site 12-23-05 consists of dry ponds adjacent to the G-Tunnel muckpile. The ponds were used to contain effluent from the G-Tunnel.

The purpose of this CADD/CR is to provide justification for the closure of CAU 552 with no further corrective action. This justification is based on process knowledge and the results of the investigative 


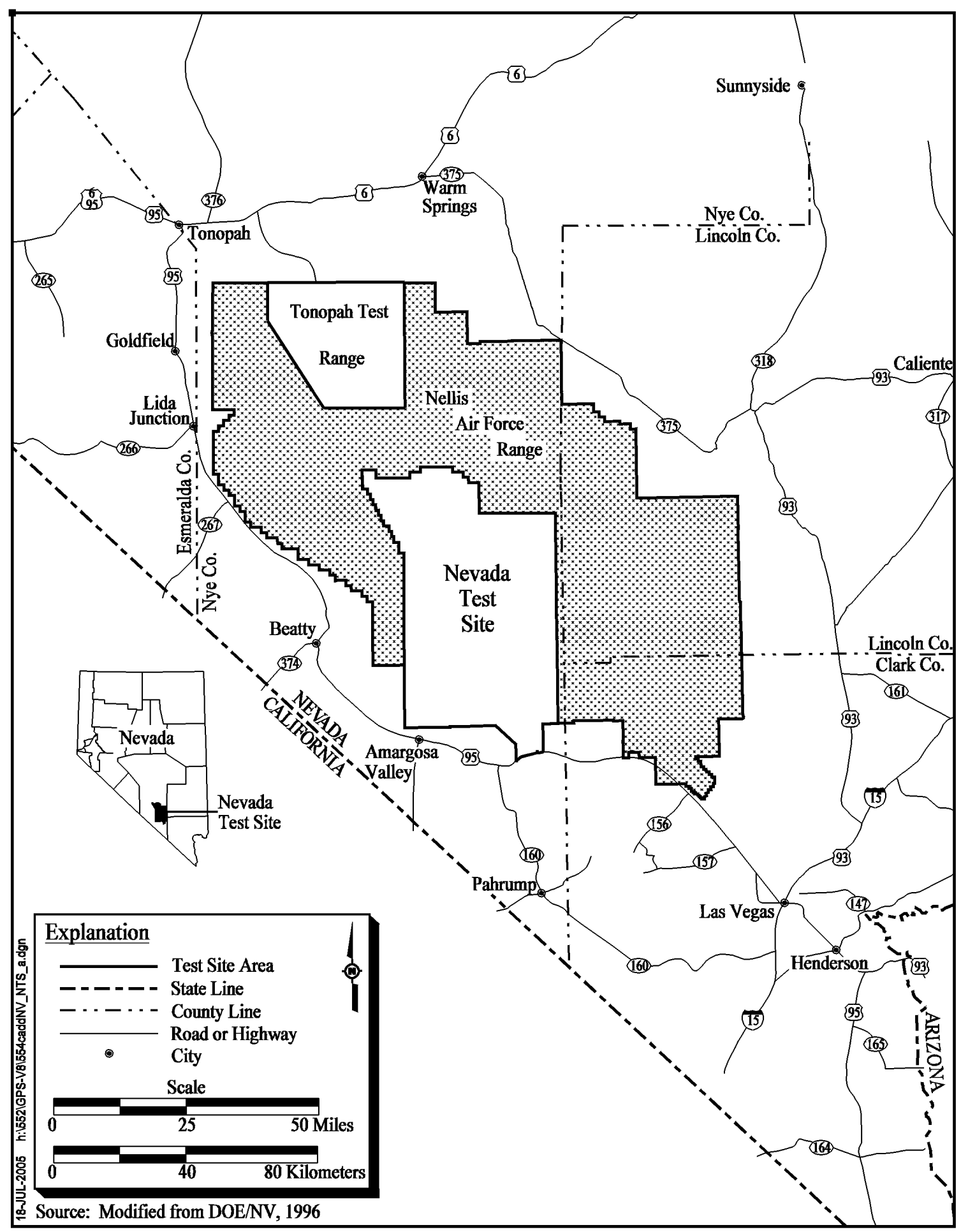

Figure 1-1

Nevada Test Site 


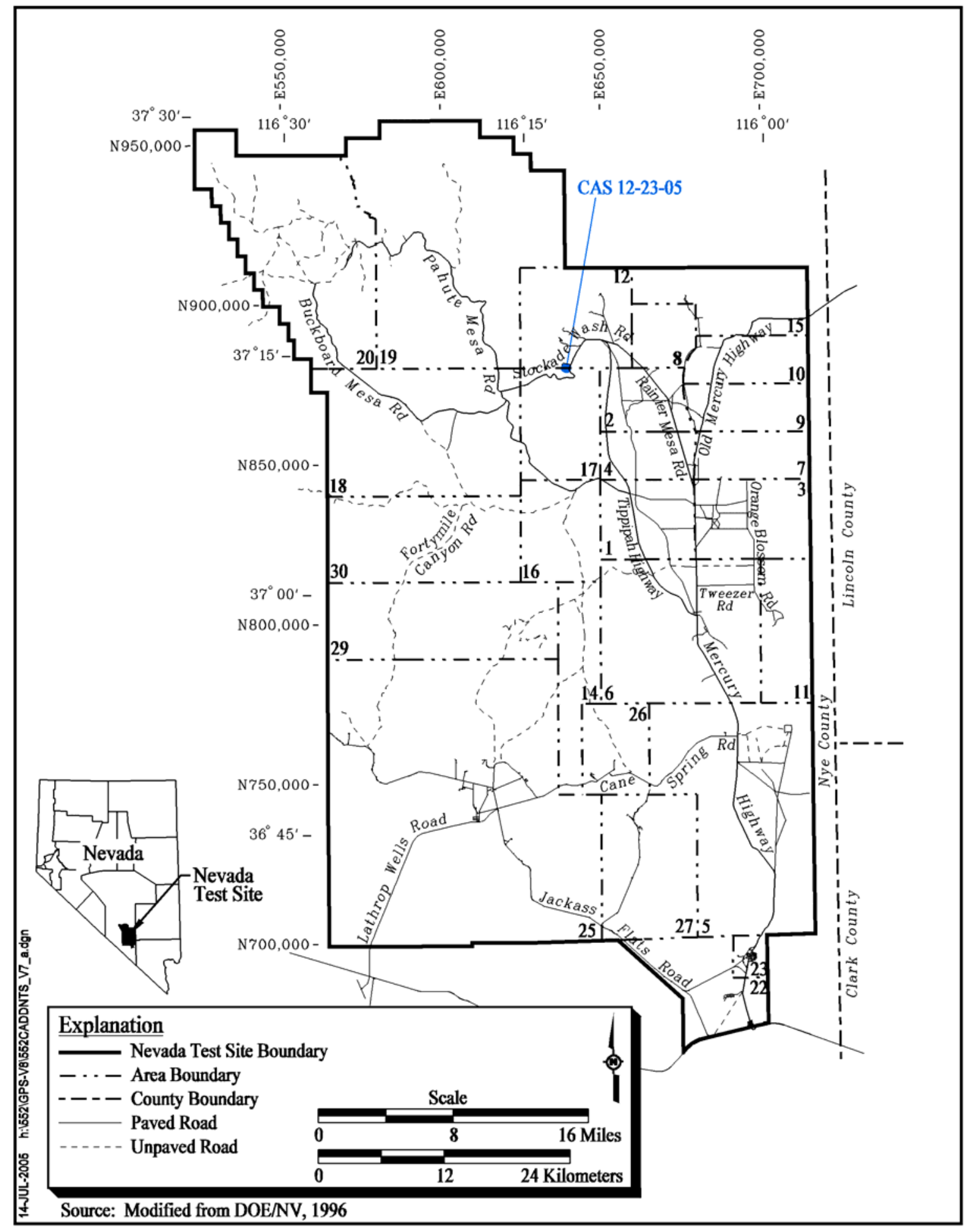

Figure 1-2

CAU 552, CAS Location Map 
activities conducted in accordance with the CAIP (NNSA/NSO, 2005) and the corresponding Records of Technical Change (ROTCs). The CAIP provides information relating to the history, planning, and scope of the investigation; therefore, this information will not be repeated in this $\mathrm{CADD} / \mathrm{CR}$.

\subsection{Scope}

The scope of this CADD/CR is to recommend that no further corrective action is required at CAU 552, Area 12 Muckpile and Ponds. To achieve this scope, the following actions were implemented:

- Evaluation of current site conditions, including the concentrations and extent of contaminants of concern (COCs).

- Justification of why no further corrective action is necessary; how and why use restrictions will be applied; and the technical rationale for implemented closure activities.

\subsection{Corrective Action Decision Document/Closure Report Contents}

This CADD/CR is divided into the following sections and appendices:

Section 1.0 - Introduction: Summarizes the purpose, scope, and contents of this CADD/CR.

Section 2.0 - Corrective Action Investigation (CAI) Summary: Summarizes the investigation field activities, the results of the investigation, the need for corrective action, and a summary of the results of the data quality objective (DQO) assessment.

Section 3.0 - Recommendation: States why closure in place is required.

Section 4.0 - References: Provides a list of all referenced documents used in the preparation of this $\mathrm{CADD} / \mathrm{CR}$.

Appendix A - Corrective Action Investigation Results for CAU 552: Provides a description of the project objectives, field investigation and sampling activities, investigation results, waste management (WM), and quality assurance (QA). Section A.3.0 provides specific 
information regarding field activities, sampling methods, and laboratory analytical results from the investigation.

Appendix B - Data Assessment for CAU 552: Provides a data quality assessment (DQA) that reconciles DQO assumptions and requirements to the investigation results.

Appendix C - Evaluation of Risk for CAU 552: Presents an evaluation of risk associated with the recommended closure in place.

Appendix D - Closure Activity Summary for CAU 552: Provides details on the completed closure activities and includes the required verification activities and supporting documentation for CAU 552.

Appendix E - Sample Location Coordinates for CAU 552: Provides investigation sample locations coordinates.

Appendix F - Use Restriction for CAU 552: Presents use restriction information for CAS 12-23-05.

\subsubsection{Applicable Programmatic Plans and Documents}

To ensure all project objectives, health and safety (H\&S) requirements, and quality control (QC) procedures were adhered to, all investigation activities were performed in accordance with the following documents:

- CAIP for CAU 552, Area 12 Muckpile and Ponds (NNSA/NSO, 2005)

- ROTC No. 1 for the CAIP for CAU 552, Area 12 Muckpile and Ponds

- $\quad$ ROTC No. 2 for the CAIP for CAU 552, Area 12 Muckpile and Ponds

- Industrial Sites Quality Assurance Project Plan (QAPP) (NNSA/NV, 2002)

- FFACO (1996)

- Project Management Plan (May, 2005)

- Approved standard quality practices and detailed operating procedures

The DQOs identified in the CAIP are as follows:

- Determine whether COCs are present.

- If COCs are present, determine their nature and extent. Obtain sufficient information to evaluate potential corrective action alternatives. 


\subsubsection{Data Quality Assessment Summary}

The Data Quality Indicators (DQIs) as discussed in Appendix B were achieved and the DQOs established in the CAIP were met. 


\subsection{Corrective Action Investigation Summary}

The following sections summarize the CAU 552 investigation activities and results. Detailed investigation activities and results for the CAU 552 CAS are presented in Appendix A of this document.

\subsection{Investigation Activities}

Corrective action investigation activities were performed as set forth in the CAU 552 CAIP (NNSA/NSO, 2005) from October 18, 2004, through April 25, 2005. The purpose of the CAU 552 CAI was to address the decision statements in the project-specific DQOs by:

- Determining whether COCs are present in the soils associated with CAU 552.

- Determining the lateral and vertical extent of identified COCs.

- Ensuring adequate data have been collected to close the sites under the Nevada Division of Environmental Protection (NDEP), Resource Conservations and Recovery Act (RCRA) (CFR, 2003a), Toxic Substance Control Act (CFR, 2003b), and DOE requirements.

The scope of the CAI included the following activities:

- Performing a land area radiological walkover survey.

- Performing a walkover geophysical survey.

- Field-screening soil samples for volatile organic compounds (VOCs) and alpha and beta/gamma radiation.

- Collecting environmental soil samples for laboratory analyses to determine the presence of COCs

- Collecting environmental soil samples for laboratory analyses to define the vertical and lateral extent of COCs.

- Collecting QC samples for laboratory analyses to ensure that the data generated from the analysis of investigation samples meet the requirements of the DQIs.

A combination of judgmental (nonprobabilistic) and random sampling schemes was implemented to select sample locations and evaluate analytical results, as outlined in the CAIP. Judgmental sampling 
allows the methodical selection of sample locations that target the populations of interest (defined in the DQOs) rather than non-selective random locations. Random sample locations were used inside the ponds due to the absence of biasing factors within the ponds. According to the CAIP, each pond is considered a separate unit, and contamination found in any of the random samples will be assumed to exist in the entire pond.

Because individual sample results, rather than an average concentration, will be used to compare to action levels, statistical methods to generate site characteristics (averages) will not be necessary. Section 0.4.4 of the U.S. Environmental Protection Agency (EPA) Data Quality Objectives Process for Hazardous Waste Site Investigations (EPA, QA/G-4HW) guidance states that the use of statistical methods may not be warranted by program guidelines or site-specific sampling objectives (EPA, 2000). The need for statistical methods is dependent upon the decisions being made. Section 7.1 of the EPA QA/G-4HW guidance states that a nonprobabilistic (judgmental) sampling design is developed when there is sufficient information on the contamination sources and history to develop a valid conceptual site model (CSM) and to select specific sampling locations. This design was used to confirm the existence of contamination at specific locations and provide information (such as extent of contamination) about specific areas of the site.

Confidence in the sampling results will be established qualitatively by: the validation of the CSM developed and concurred to by stakeholder participants DOE, National Nuclear Security Administration Nevada Site Office (NNSA/NSO) and (NDEP) during the DQO process based on investigation results; and performing a DQA to determine whether DQA requirements were met.

\subsubsection{Ponds (CAS 12-23-05)}

The following sections summarize the land area radiological walkover survey, field screening, and intrusive investigation activities conducted at CAS 12-23-05.

\subsubsection{Land Area Radiological Walkover Survey}

A land area radiological walkover survey was performed over the G-Tunnel ponds and surrounding berms to protect worker $\mathrm{H} \& \mathrm{~S}$ and to identify potential radioactive waste in support of WM activities. The scope of the CAI was to define the radiological contamination from effluent generated during 
G-Tunnel related projects. The results of the land area radiological walkover survey show an area with slightly elevated gamma radioactivity located at the upper pond. The source of the radioactivity is believed to be attributed to past radiological operations and/or testing activities conducted at G-Tunnel. Corrective Action Site 12-23-05 is identified as an underground radioactive material area (RMA) because of past site operations.

\subsubsection{Geophysical Walkover Survey}

A geophysical walkover survey was performed over the toe of the muckpile to identify subsurface piping. The results of the geophysical walkover survey show a shallow subsurface linear anomaly caused by a buried pipe or metal culvert west of the upper pond. No evidence of a pipe between the upperpond and the muckpile is observable.

\subsubsection{Field Screening}

Field screening was conducted on soil samples using a handheld alpha, beta/gamma radiological survey instrument. The field-screening results (FSRs) were compared to field-screening levels (FSLs) to guide subsequent soil sampling decisions and to determine which samples were submitted for laboratory analysis.

\subsubsection{Intrusive Investigation}

A total of 66 soil samples from 37 locations were collected and submitted to the laboratory for the analyses listed in Appendix A (Table A.2-3). Soil samples were collected using "scoop and trowel" (grab sampling), hand auger, and rotosonic drilling methods.

Surface soil samples were collected from 0.0 to 0.5 feet (ft) below ground surface (bgs) or 0.0 to $1.0 \mathrm{ft}$ bgs. Most surface soil samples were collected using grab sampling techniques. Biased locations focused on stained soil, areas with low topography, or areas with elevated radiological measurements. Random locations at which pond sediment existed were sampled at a random depth within the sediment and at the sediment/native soil interface.

Subsurface soil samples were collected from various depth intervals ranging from 1 to $2 \mathrm{ft}$ bgs up to and including 8 to $9 \mathrm{ft}$ bgs at selected sample locations using rotosonic drilling and hand augering 
techniques. Some selected soil samples with FSRs exceeding FSLs were also collected and submitted for off-site laboratory analysis. Additional information regarding this investigation activity is presented in Appendix A (Section A.4.0)

\subsubsection{Waste Characterization}

Waste characterization activities were conducted to provide sufficient information and data to support waste disposal decisions. Two soil samples were collected from beneath two batteries located just north of the easternmost pond. In addition, the analytical results from the environmental soil sampling and radiological screening were used to determine the proper disposition of the investigation-derived waste (IDW).

\subsubsection{Laboratory Analysis}

Laboratory analysis of soil samples provided the means for the quantitative measurement of contaminants of potential concern (COPCs). Samples sent to the off-site laboratory were analyzed for the following parameters stipulated in the analytical program defined in the CAIP: total VOCs, total semivolatile organic compounds (SVOCs), total RCRA metals, total beryllium, total petroleum hydrocarbons (TPH) (diesel-range organics [DRO] and gasoline-range organics [GRO]), polychlorinated biphenyls (PCBs), isotopic uranium, strontium-90, and gamma-emitting radionuclides. Table 3-2 in the CAU 552 CAIP (NNSA/NSO, 2005) lists the planned analytical program for CAU 552.

\subsubsection{Conceptual Site Model Validation}

A CSM was developed to represent the release mechanisms and potential migration pathways for contaminant releases at the CAU 552 CAS. The CSM and associated discussion for this CAS are provided in the CAIP. The CSM addressed surface and shallow subsurface soils potentially impacted by releases of COPCs from the G-Tunnel muckpile and direct waste addition to the ponds. The release mechanisms include runoff from the G-Tunnel muckpile, piping of contaminated effluent into the ponds, and other depositions of COPCs into the ponds.

The CSM assumed that all contaminant migration would be minimal based on the affinity of the COPCs for soil particles, and the low precipitation and high potential evapotranspiration rates typical 
of the NTS environment. Additionally, contaminant migration was expected to be minimized by the use of berms surrounding the ponds. The extent of subsurface soil impact was expected to be minimal and dependent upon length of time liquids remain standing in the ponds and the amount of COPCs through the soil column. Additional contaminant migration was anticipated from pond overfills that allowed migration to occur outside the ponds to the surrounding soils.

The migration pathway and release mechanism information collected during the CAI was consistent with the CSM, and all information gathered during the CAI supports and validates the CSM as presented in the CAIP.

\subsection{Results}

A data summary of data obtained from the CAI is presented in Section 2.2.1. Section 2.2.2 summarizes the assessment made in Appendix B, which demonstrates that the investigation results satisfy the DQO data requirements.

\subsubsection{Summary of Analytical Data}

The preliminary action levels (PALs) for the investigation were determined during the DQO process and are discussed in Section 3.3 of the CAIP (NNSA/NSO, 2005). Final action levels (FALs) are presented in Section 2.3.1. The COPCs identified during the CAI were evaluated against the FALs to identify COCs.

Cesium (Cs)-137 was identified above the PAL in five sediment samples and one soil sample in the upper pond. Total petroleum hydrocarbons-DRO was identified above the PAL of 100 parts per million (ppm) in seven soil samples, including sediment and native soil in the upper pond, soil sampled beneath two batteries found north of the lower pond, and samples collected in the drainage area east of the ponds. However, these samples did not exceed the risk-based FAL for TPH, as defined in Section 2.3.1. Cesium-137 is the only COC identified at CAS 12-23-05. Analytical results associated with CAS 12-23-05 are further detailed in Section A.3.2. 


\subsubsection{Data Assessment Summary}

The DQA is presented in Appendix B and includes an evaluation of the DQIs to determine the degree of acceptability and usability of the reported data in the decision-making process. The DQO process ensures that the right type, quality, and quantity of data will be available to support the resolution of those decisions at an appropriate level of confidence. Using both the DQO and DQA processes help to ensure that DQO decisions are sound and defensible.

The DQA process as presented in Appendix B is comprised of the following steps:

- Step 1: Review DQOs and Sampling Design.

- Step 2: Conduct a Preliminary Data Review.

- Step 3: Select the Test.

- Step 4: Verify the Assumptions.

- Step 5: Draw Conclusions from the Data.

Sample locations that support the presence and/or extent of contamination at each CAS are shown in Appendix A. Based on the results of the DQA presented in Appendix B, the DQO requirements have been met and close in place with use restriction was selected as the closure alternative. The DQA also determined that information generated during the investigation supports the CSM assumptions and the data collected support their intended use in the decision-making process.

\subsection{Justification for No Further Action}

No further corrective action is justified because corrective actions have been implemented at this site (close in place with a use restriction). This corrective action was determined from DQO decision statements based on a comparison of the analyte concentrations detected in CAI soil samples to the FALs defined in Section 2.3.1.

Cesium-137 is the only contaminant identified as a COC at CAS $12-23-05$, and the contamination is confined to the upper pond. Due to the continued presence of the source of contamination (the G-Tunnel muckpile) and the associated risk of future contamination of the CAS, clean closure of the site was not a feasible corrective action. Instead, a use restriction was placed on the area surrounding and including the upper pond. The use restriction shall prevent unauthorized entry into the area through demarcation and postings. An annual post-closure inspection is associated with the use 
restriction to certify that markers and postings are in place, intact, and readable. The use restriction is included in Appendix F. Based on close in place, no evaluation of radiological risk was necessary at 12-23-05.

\subsubsection{Final Action Levels}

The CAU 552 corrective action objective for chemical criteria is a risk-based cleanup goal defined herein as FALs that, if met, will ensure that each release site will not pose an unacceptable risk to human health and the environment and that conditions at each site are in compliance with all applicable laws and regulations. The process described in this section to define or determine the FALs is in conformance with Nevada Administrative Code (NAC) Section 445A.227, which lists the requirements for sites with soil contamination (NAC, 2003). For the evaluation of corrective actions, NAC Section 445A.22705 requires the use of American Society for Testing and Materials (ASTM) Method E1739-95 to "conduct an evaluation of the site, based on the risk it poses to public health and the environment, to determine the necessary remediation standards (i.e., FALs) or to establish that corrective action is not necessary" (ASTM, 1995).

The ASTM procedure defines three tiers (or levels) of evaluation involving increasingly sophisticated analyses:

Tier 1 Evaluation - Sample results from source areas (highest concentrations) are compared to action levels based on generic (non-site-specific) conditions (i.e., the PALs established in the CAIP). The FALs may then be established as the Tier 1 action levels, or the FALs may be calculated using a Tier 2 evaluation.

Tier 2 Evaluation - Sample results from exposure points are compared to action levels calculated using site-specific inputs (Tier 2 action level). The FALs may be established as the Tier 2 action levels, or the FALs may be calculated using a Tier 3 evaluation.

Tier 3 Evaluation - Sample results from exposure points are compared to action levels and points of compliance calculated using chemical fate/transport and probabilistic modeling. The FALs for all Tier 3 constituents are established at the Tier 3 action levels. 
The FALs for all CAU 552 COPCs are shown in Table 2-1. The PALs for all COPCs were established as the FALs except for TPH-DRO. The FALs for the hazardous constituents of TPH-DRO were established as Region 9 Preliminary Remediation Goals (PRGs). For more details on how FALs were determined, refer to Appendix C. More details about the methods used during this investigation and a comparison of environmental sample results to the respective PALs and FALs are presented in Appendix A.

Table 2-1

Definition of Final Action Levels

\begin{tabular}{|c|c|c|c|}
\hline COPCs & Tier 1 Based FAL & Tier 2 Based FALs & Tier 3 Based FALs \\
\hline \hline $\begin{array}{c}\text { Volatile Organic } \\
\text { Compounds }\end{array}$ & PALs & NA & NA \\
\hline $\begin{array}{c}\text { Semivolatile Organic } \\
\text { Compounds }\end{array}$ & PALs & NA & NA \\
\hline PCBs & PALs & NA & NA \\
\hline RCRA Metals & PALs & NA & NA \\
\hline TPH-GRO & PALs & Region 9 PRGs for TPH-DRO & NA \\
\hline TPH-DRO & NA & PALs & NA \\
\hline Radionuclides & NA & NA \\
\hline
\end{tabular}

COPC $=$ Contaminant of potential concern

$\mathrm{DRO}=$ Diesel-range organics

$\mathrm{GRO}=$ Gasoline-range organics

$\mathrm{FAL}=$ Final action level

$\mathrm{NA}=$ Not applicable

$\mathrm{PAL}=$ Preliminary action level

PRG = Preliminary Remediation Goal

RCRA = Resource Conservation and Recovery Act

$\mathrm{TPH}=$ Total petroleum hydrocarbons 


\subsection{Recommendation}

Close in place with use restriction is recommended based on technical merits, focusing on performance, reliability, feasibility, and safety. No further corrective action is required at CAU 552 based on the presence of Cs-137 in surface soils in the upper pond.

Clean closure of the site was not feasible due to the potential of contaminants migrating from the muckpile into the upper pond. Therefore, it is recommended that contamination in the upper pond be reassessed after the closure of the G-Tunnel muckpile. The use restriction implemented by this document may be revoked following a future corrective action that may eliminate the need for a use restriction at this site.

Appendix D provides details for the use restriction to be implemented at the site as part of the CAU closure, Figure F.1-1 shows the use-restricted area with global positioning system (GPS) coordinates. This approach has been judged to meet all applicable state and federal regulations for closure of the site and will minimize potential future exposure pathways to the contaminated media at CAU 552.

The NNSA/NSO requests that NDEP issue a Notice of Completion for this CAU and approval to move the CAU from Appendix III to Appendix IV of the FFACO, with the provision that contamination in the upper pond will be reassessed after the closure of the G-Tunnel muckpile. 


\subsection{References}

ASTM, see American Society for Testing and Materials.

American Society for Testing and Materials. 1995. Standard Guide for Risk-Based Corrective Action Applied at Petroleum Release Sites/American Society for Testing and Materials, ASTM E 1739-95 (Reapproved 2002). Philadelphia, PA.

CFR, see Code of Federal Regulations.

Code of Federal Regulations. 2003a. Title 40 CFR Parts 260 - 282, "Hazardous Waste Management." Washington, DC: U.S. Government Printing Office.

Code of Federal Regulations. 2003b. Title 40 CFR 761, "Polychlorinated Biphenyls (PCBs) Manufacturing, Processing, Distribution in Commerce and Prohibitions." Washington, DC: U.S. Government Printing Office.

DOE/NV, see U.S. Department of Energy, Nevada Operations Office.

EPA, see U.S. Environmental Protection Agency.

FFACO, see Federal Facility Agreement and Consent Order.

Federal Facility Agreement and Consent Order. 1996 (as amended). Agreed to by the State of Nevada, the U.S. Department of Energy, and the U.S. Department of Defense.

NAC, see Nevada Administrative Code.

NNSA/NSO, see U.S. Department of Energy, National Nuclear Security Administration Nevada Site Office.

NNSA/NV, see U.S. Department of Energy, National Nuclear Security Administration Nevada Operations Office.

Nevada Administrative Code. 2003. NAC 445A, "Water Controls.” Carson City, NV.

U.S. Department of Energy, National Nuclear Security Administration Nevada Operations Office. 2002. Industrial Sites Quality Assurance Project Plan, Nevada Test Site, Nevada, Rev. 3, DOE/NV--372. Las Vegas, NV.

U.S. Department of Energy, National Nuclear Security Administration Nevada Site Office. 2005. Corrective Action Investigation Plan for Corrective Action Unit 552: Area 12 Muckpile and Ponds, Nevada Test Site, Nevada, Rev. 1, DOE/NV--962. Las Vegas, NV. 
U.S. Department of Energy, Nevada Operations Office. 1996. Final Environmental Impact Statement for the Nevada Test Site and Off-Site Locations in the State of Nevada, DOE/EIS 0243. Las Vegas, NV.

U.S. Environmental Protection Agency. 2000. Data Quality Objectives Process for Hazardous Waste Site Investigations, EPA QA/G-4HW, EPA/600/R-00/007. Washington, DC: Office of Environmental Information. 
Appendix A

Corrective Action Investigation Results for CAU 552 


\section{A.1.0 Introduction}

This appendix details CAI activities and analytical results for CAU 552. Corrective Action Unit 552 is located in Area 12 of the NTS (Figure 1-1 of the main document), and is comprised of the CAS listed below:

- 12-23-05, Ponds

Corrective Action Site 12-23-05 consists of ponds used for the containment of effluent generated from work performed at G-Tunnel, as well as for containment of runoff from the G-Tunnel muckpile.

The three ponds are located in Area 12 of the NTS and lay off the eastern slope of the G-Tunnel muckpile. Beginning at the toe of the muckpile, the ponds extend sequentially towards the east and were fed by pipes that drain overflow from one pond to another. The berms are man made and surround each pond to a height of approximately 3 to $4 \mathrm{ft}$ above natural grade. The pipes connecting the ponds are buried approximately $1 \mathrm{ft}$ below the height of the berm walls so that overflow from one pond is diverted to the next pond further away from the muckpile. The integrity of the berm walls is intact, and there is no visual evidence of wall collapse or breach (Figure A.1-1). Soil contamination originating from the fallout of atmospheric nuclear weapons testing in the vicinity of CAS 12-06-04 is not considered part of this CAU as specified in the CAIP (NNSA/NSO, 2005). Additional detail is provided in the CAIP (NNSA/NSO, 2005).

This CAU was investigated because process knowledge indicated the associated CAS may have been used to store or dispose of material considered to be hazardous or radioactive waste by current standards. The CAI was conducted in accordance with the CAU 552 CAIP (NNSA/NSO, 2004) as developed under the FFACO (1996).

Additional information regarding the history of the site, planning, and the scope of the investigation is presented in the CAU 552 CAIP (NNSA/NSO, 2005). 


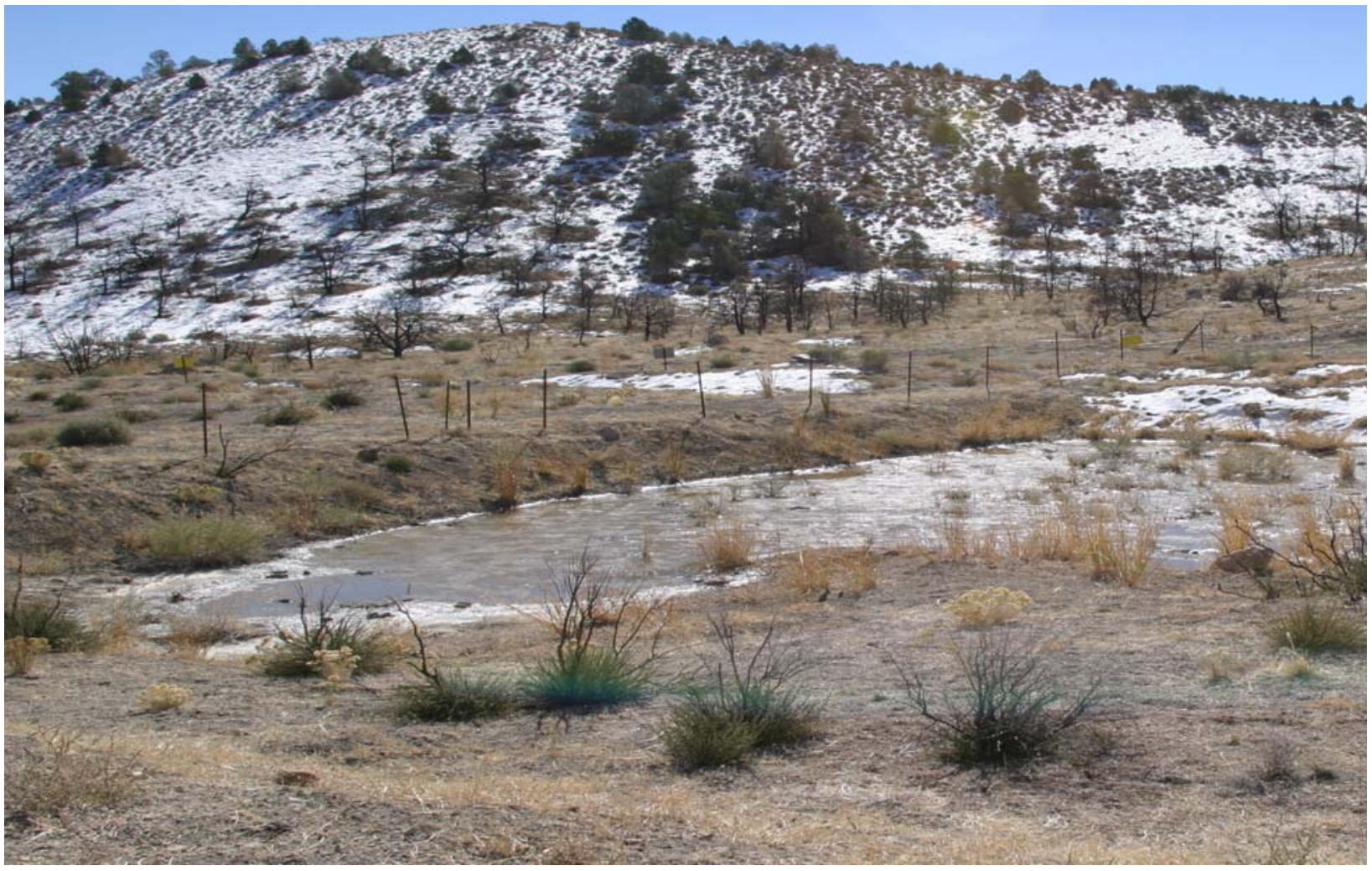

Figure A.1-1

\section{CAU 552 Upper Pond}

The photo was taken looking southwest and shows the man-made berm.

(Photograph taken on November 4, 2004)

\section{A.1.1 Project Objectives}

The primary objective of the investigation was to provide sufficient information and data to develop appropriate corrective action alternatives for the CAS in CAU 552. This objective was achieved by identifying the absence or presence of COPCs, the nature of the COCs (i.e., COPCs at concentrations above FALs), and the vertical and lateral extent of the COCs.

The selection of soil and/or waste characterization sample locations was based on site conditions, and the strategy developed during the DQO process as outlined in the CAU 552 CAIP. The sampling strategy involved the collection of samples at biased sample locations with random samples collected at locations where no biasing factors are present. 


\section{A.1.2 Content}

This appendix describes the investigation activities and presents the analytical results in sufficient detail to support the selection of a corrective action alternative and a recommendation that no further action is necessary for CAS 12-23-05. The contents of this appendix are as follows:

- Section A.1.0 describes the investigation background, objectives, and content.

- Section A.2.0 provides an investigation overview, including information regarding the field activities, sampling methods, and laboratory analytical results from investigation sampling.

- $\quad$ Section A.3.0 summarizes WM activities.

- Section A.4.0 discusses the quality assurance QA and QC procedures followed and results of the QA/QC activities.

- Section A.5.0 lists the cited references.

The complete field documentation and laboratory data, including field activity daily logs, sample collection logs (SCLs), analysis request/chain-of-custody forms, soil sample descriptions, laboratory certificates of analyses, analytical results, and surveillance results are retained in project files as hard copy files or electronic media. 


\section{A.2.0 Investigation Overview}

Field investigation and sampling activities for the CAU 552 CAI were conducted from

November 18, 2004, to April 25, 2005. Table A.2-1 lists the CAI activities that were conducted at the CAS.

Table A.2-1

Corrective Action Investigation Activities Conducted at Each Corrective Action Site To Meet Corrective Action Investigation Plan Requirements

\begin{tabular}{|l|c||}
\hline \multicolumn{1}{|c|}{ Corrective Action Investigation Activities } & Corrective Action Site \\
\cline { 2 - 3 } & $\mathbf{1 2 - 2 3 - 0 5}$ \\
\hline \hline Inspected CAS system components & $\mathrm{X}$ \\
\hline Conducted surface land area radiological walkover surveys & $\mathrm{X}$ \\
\hline Conducted geophysical walkover survey & $\mathrm{X}$ \\
\hline Performed site transects/walkovers & $\mathrm{X}$ \\
\hline Collected biased soil samples & $\mathrm{X}$ \\
\hline Collected random soil samples & $\mathrm{X}$ \\
\hline Field screened samples for alpha and beta/gamma radiation & $\mathrm{X}$ \\
\hline Field screened soil samples for volatile organic compounds (Decision I sampling only) & $\mathrm{X}$ \\
\hline Submitted select samples for off-site laboratory analysis & $\mathrm{X}$ \\
\hline Conducted waste characterization sampling & \\
\hline
\end{tabular}

The investigation and sampling program was managed in accordance with the requirements set forth in the CAU 552 CAIP (NNSA/NSO, 2005). Field activities were performed in accordance with the approved Industrial Sites Project Health and Safety Plan (SNJV, 2004), which is consistent with the DOE Integrated Safety Management System. Samples were collected and documented following approved protocols and procedures. Quality control samples (e.g., field blanks, equipment rinsate blanks, trip blanks, and duplicate samples) were collected as required by the Industrial Sites QAPP (NNSA/NV, 2002) and the CAU 552 CAIP (NNSA/NSO, 2005). During field activities, waste 
minimization practices were followed according to approved procedures, including segregation of waste by waste stream.

Weather conditions at the site varied to include winter seasonal sun (cool to cold temperatures), rain, snow, intermittent cloudiness, and light to strong winds. Winds and storms (accompanied by rain or snow) occasionally delayed site operations.

The CAS was investigated by conducting radiological surface screening and surveys and sampling potential contaminant sources, surface, and subsurface soils. Surface soil samples were collected by hand excavation and drilling procedures. Subsurface soil samples were collected using hand augering and drilling operations. Investigation intervals and soil samples were field screened for VOCs and alpha and beta/gamma radiation. The results were compared against screening levels to guide in the CAS-specific investigations. Resultant samples were shipped to off-site laboratories to be analyzed for appropriate chemical and radiological parameters. The field-screening readings were also used to guide sampling decisions and H\&S controls.

Except as specifically noted, CAU 552 sampling locations were accessible and sampling activities at planned locations were not restricted by buildings, storage areas, active operations, or aboveground and underground utilities, although the presence of water within the upper pond delayed sampling activities. Required sampling step-out locations were accessible and remained within anticipated spatial boundaries except where otherwise noted.

Section A.2.1 through Section A.2.6 provide the investigation methodology, site geology and hydrology, and laboratory analytical information.

\section{A.2.1 Sample Locations}

Investigation locations selected for sampling were based on interpretation of existing engineering drawings, aerial and land photographs, interviews with former and current site employees, information obtained during site visits, site conditions and a random sampling scheme, as provided in the CAU 552 CAIP. The planned biased and random sample locations are discussed in text and depicted on figures in the CAIP. All actual sample locations are depicted in Figure A.2-1 and Figure A.2-2. Some locations were modified slightly from planned positions due to field conditions and observations. Sample locations were staked, labeled appropriately, and surveyed with a GPS 
instrument. The actual locations have been plotted based on the coordinates collected by the GPS instrument. Sample location coordinates are provided in Appendix E.

\section{A.2.2 Investigation Activities}

The investigation activities performed at CAU 552 were based on general field investigation activities discussed in the CAU 552 CAIP (NNSA/NSO, 2005). The technical approach consisted of the activities listed in Table A.2-1. The investigation strategy allowed the nature and extent of contamination associated with CAU 552 to be established. The following sections describe the specific investigation activities that took place at CAU 552.

\section{A.2.2.1 Surface Radiological Surveys}

Land-area radiological walkover surveys were performed on CAS 12-23-05 to support unrestricted release determinations per the NV/YMP Radiological Control Manual (DOE/NV, 2000). The surveys were performed to identify the presence and extent of surficial beta/gamma-emitting radiological contaminants at activities statistically greater than background. This was done using a TSA Model PRM-470B handheld scintillation detector in conjunction with a Trimble Pathfinder Pro XRS ${ }^{\mathrm{TM}}$ Global Positioning Receiver with TSCI ${ }^{\mathrm{TM}}$ Datalogger.

The CAS area surveyed were the G-Tunnel muckpile ponds and berms, as well as a drainage leading east of the ponds. The results of the land-area radiological walkover survey show localized areas of elevated count rates within the upper pond.

\section{A.2.2.2 Site Walkovers}

A site walkover was performed on CAS 12-23-05 within CAU 552. This was accomplished by walking transects spaced a maximum of $40 \mathrm{ft}$ apart. Biased sampling locations were determined based on visual observations (e.g., stained soil, low topographic areas, unidentified or out-of-place objects), and results from the radiological survey.

\section{A.2.2.3 Field Screening}

Field-screening activities for VOCs and alpha and beta/gamma radiation were performed as specified in the CAU 552 CAIP. The FSL for VOC headspace was established at 20 ppm or 2.5 times 
background, whichever was greater. Site-specific FSLs for alpha and beta/gamma radiation were defined as the mean background activity level plus two times the standard deviation of readings from 10 background locations selected near the CAS. The radiation FSLs are instrument-specific and were established for each instrument and CAS before use.

All field screening for VOCs was conducted using a flame-ionization detector (FID) during Decision I activities at the CAS. Alpha and beta/gamma radiation screening was performed at each CAS using a handheld alpha and beta/gamma radiological survey instrument.

The VOC headspace results did not exceed FSLs; however, the alpha and beta/gamma radiation FSLs were exceeded at several sampling locations. Gamma spectroscopy was performed on some samples since radiological field instrumentation is unreliable with moist soils.

Field-screening results are recorded on SCLs that are retained in project files (SNJV, 2005).

\section{A.2.2.4 Surface and Subsurface Sampling}

Intrusive investigation activities (i.e., surface and subsurface soil sampling), were conducted at CAS 12-23-05 within CAU 552 to support Decision I and Decision II investigation activities. Soil samples were collected using "scoop and trowel" (grab sampling), hand auger, and rotosonic drilling. Screening was conducted during sample collection to both guide the investigation and serve as an $H \& S$ control to protect the sampling team. Labeled sample containers were filled according to the following sequence: total VOCs and TPH-GRO sample containers were filled with soil directly from the surface location, followed by the collection of soil for VOC field screening using headspace analysis. Additional soil was transferred into a stainless-steel bowl, homogenized, and field screened for alpha and beta/gamma radiation. All remaining sample containers were then filled. Excess soil was returned to its original location. No void spaces remained in the boreholes after backfilling with cuttings.

A total of 66 soil characterization samples (including 4 field duplicates) were collected during investigation activities at CAS 12-23-05. The sample identification numbers (IDs), locations, types, and analyses are listed in Table A.2-2. The sample locations are shown on Figure A.2-1 and Figure A.2-2. The specific CAI activities conducted to satisfy the CAIP requirements at this CAS are described in the following sections. 
Table A.2-2

Samples Collected at CAS 12-23-05, Ponds

(Page 1 of 3 )

\begin{tabular}{|c|c|c|c|c|c|}
\hline $\begin{array}{l}\text { Sample } \\
\text { Location }\end{array}$ & $\begin{array}{l}\text { Sample } \\
\text { Number }\end{array}$ & $\begin{array}{c}\text { Depth } \\
\text { (ft bgs) }\end{array}$ & Matrix & Purpose & Analyses \\
\hline \multirow{3}{*}{ B01 } & 552B001 & $0.0-0.5$ & Soil & Environmental & Set 1 \\
\hline & 552B015 & $0.0-1.0$ & Soil & Environmental & Set 1 \\
\hline & 552B025 & $5.0-6.0$ & Soil & Environmental & Set 1 \\
\hline \multirow{4}{*}{ B02 } & 552B002 & $0.0-0.5$ & Soil & Environmental & Set 1 \\
\hline & 552B003 & $0.0-0.5$ & Soil & Field Duplicate of \#552B002 & Set 1 \\
\hline & 552B012 & $0.0-1.0$ & Soil & Environmental & Set 1 \\
\hline & 552B013 & $5.0-6.0$ & Soil & Environmental & Set 1 \\
\hline \multirow{2}{*}{ B03 } & 552B004 & $0.0-0.5$ & Soil & Environmental, MS/MSD & Set 1 \\
\hline & 552B024 & $6.0-7.0$ & Soil & Environmental & Set 1 \\
\hline \multirow{4}{*}{ B04 } & 552B005 & $0.0-0.5$ & Soil & Environmental & Set 1 \\
\hline & 552B017 & $0.0-1.0$ & Soil & Environmental & Set 1 \\
\hline & 552B022 & $4.0-5.0$ & Soil & Environmental & Set 1 \\
\hline & 552B023 & $4.0-5.0$ & Soil & Field Duplicate of \#552B022 & Set 1 \\
\hline \multirow{4}{*}{ B05 } & 552B006 & $0.0-0.5$ & Soil & Environmental & Set 1 \\
\hline & 552B018 & $0.0-1.0$ & Soil & Environmental & Set 1 \\
\hline & 552B019 & $8.0-9.0$ & Soil & Environmental & Set 1 \\
\hline & 552B026 & $6.0-7.0$ & Soil & Environmental & Set 1 \\
\hline \multirow{2}{*}{ B06 } & 552B007 & $0.0-0.5$ & Soil & Environmental & Set 1 \\
\hline & 552B027 & $4.5-5.0$ & Soil & Environmental & Set 1 \\
\hline \multirow{2}{*}{ B07 } & 552B008 & $0.0-0.5$ & Soil & Environmental & Set 1 \\
\hline & 552B034 & $2.0-3.0$ & Soil & Environmental & Set 1 \\
\hline B08 & 552B009 & $0.0-0.5$ & Soil & Environmental & Set 1 \\
\hline B09 & 552B010 & $0.0-0.5$ & Soil & Environmental & Set 1 \\
\hline B10 & 552B011 & $0.0-0.5$ & Soil & Environmental & Set 1 \\
\hline \multirow{2}{*}{ B11 } & 552B054 & $0.0-0.5$ & Soil & Environmental & Set 1 \\
\hline & 552B055 & $4.0-4.5$ & Soil & Environmental & Set 1 \\
\hline \multirow{2}{*}{ B12 } & 552B056 & $0.0-0.5$ & Soil & Environmental & Set 1 \\
\hline & 552B057 & $4.0-4.5$ & Soil & Environmental & Set 1 \\
\hline B13 & 552B058 & $0.0-0.5$ & Soil & Environmental & Set 1 \\
\hline B14 & 552B059 & $0.0-0.5$ & Soil & Environmental & Set 1 \\
\hline B15 & 552B060 & $0.0-0.5$ & Soil & Environmental & Set 1 \\
\hline
\end{tabular}


Table A.2-2

Samples Collected at CAS 12-23-05, Ponds

(Page 2 of 3 )

\begin{tabular}{|c|c|c|c|c|c|}
\hline $\begin{array}{l}\text { Sample } \\
\text { Location }\end{array}$ & $\begin{array}{l}\text { Sample } \\
\text { Number }\end{array}$ & $\begin{array}{c}\text { Depth } \\
\text { (ft bgs) }\end{array}$ & Matrix & Purpose & Analyses \\
\hline \multirow{2}{*}{ BB01 } & 552B016 & $1.0-2.0$ & Soil & Environmental & Set 1 \\
\hline & 552B021 & $4.0-5.0$ & Soil & Environmental, MS/MSD & Set 1 \\
\hline \multirow{2}{*}{ BB02 } & 552B032 & $0.0-0.5$ & Soil & Environmental & Set 1 \\
\hline & 552B033 & $2.0-3.0$ & Soil & Environmental & Set 1 \\
\hline \multirow{2}{*}{ BR01 } & 552B014 & $0.0-1.0$ & Soil & Environmental & Set 1 \\
\hline & 552B020 & $4.0-5.0$ & Soil & Environmental & Set 1 \\
\hline BR02 & 552B028 & $0.0-0.5$ & Soil & Environmental & Set 1 \\
\hline BR03 & 552B029 & $0.0-0.5$ & Soil & Environmental & Set 1 \\
\hline BR04 & 552B030 & $0.0-0.5$ & Soil & Environmental & Set 1 \\
\hline BR05 & 552B031 & $0.0-0.5$ & Soil & Environmental & Set 1 \\
\hline \multirow{2}{*}{ BR06 } & 552B061 & $1.0-1.5$ & Soil & Environmental & Set 1 \\
\hline & 552B062 & $3.0-3.5$ & Soil & Environmental & Set 1 \\
\hline \multirow{2}{*}{ BR07 } & 552B051 & $0.5-1.0$ & Soil & Environmental & Set 1 \\
\hline & 552B052 & $2.5-3.0$ & Soil & Environmental & Set 1 \\
\hline \multirow{3}{*}{ BR08 } & 552B043 & $0.0-1.0$ & Soil & Environmental, MS/MSD & Set 1 \\
\hline & 552B044 & $1.0-2.0$ & Soil & Environmental & Set 1 \\
\hline & 552B045 & $1.0-2.0$ & Soil & Field Duplicate of \#552B044 & Set 1 \\
\hline \multirow{2}{*}{ BR09 } & 552B066 & $1.0-1.5$ & Soil & Environmental & Set 1 \\
\hline & 552B067 & $3.0-3.5$ & Soil & Environmental & Set 1 \\
\hline BR10 & 552B040 & $0.0-1.0$ & Soil & Environmental & Set 1 \\
\hline \multirow{2}{*}{ BR11 } & 552B035 & $1.0-2.0$ & Soil & Environmental & Set 1 \\
\hline & 552B036 & $2.0-3.0$ & Soil & Environmental & Set 1 \\
\hline BR12 & 552B050 & $0.0-0.5$ & Soil & Environmental & Set 1 \\
\hline \multirow{3}{*}{ BR13 } & 552B063 & $0.5-2.0$ & Soil & Environmental, MS/MDS & Set 1 \\
\hline & 552B064 & $3.0-4.0$ & Soil & Environmental & Set 1 \\
\hline & 552B065 & $3.0-4.0$ & Soil & Field Duplicate of \#552B064 & Set 1 \\
\hline BR14 & 552B047 & $0.5-1.0$ & Soil & Environmental & Set 1 \\
\hline BR15 & 552B039 & $0.0-1.0$ & Soil & Environmental & Set 1 \\
\hline BR16 & 552B046 & $0.5-1.0$ & Soil & Environmental & Set 1 \\
\hline \multirow{2}{*}{ BR17 } & 552B037 & $1.5-2.0$ & Soil & Environmental & Set 1 \\
\hline & 552B038 & $2.5-3.0$ & Soil & Environmental & Set 1 \\
\hline
\end{tabular}


Table A.2-2

Samples Collected at CAS 12-23-05, Ponds

(Page 3 of 3 )

\begin{tabular}{|c|c|c|c|c|c||}
\hline $\begin{array}{c}\text { Sample } \\
\text { Location }\end{array}$ & $\begin{array}{c}\text { Sample } \\
\text { Number }\end{array}$ & $\begin{array}{c}\text { Depth } \\
\text { (ft bgs) }\end{array}$ & Matrix & Purpose & Analyses \\
\hline \multirow{2}{*}{ BR18 } & $552 \mathrm{~B} 041$ & $0.0-1.0$ & Soil & Environmental & Set 1 \\
\cline { 2 - 6 } Battery 1 & $552 \mathrm{~B} 042$ & $2.0-2.5$ & Soil & Environmental & Set 1 \\
\hline Battery 2 & $552 \mathrm{~B} 048$ & $0.0-0.5$ & Soil & Environmental & Set 1 \\
\hline NA & $552 \mathrm{~B} 049$ & $0.0-0.5$ & Soil & Environmental & Set 1 \\
\hline NA & $552 \mathrm{~B} 301$ & NA & Water & Trip Blank & Total VOCs \\
\hline NA & $552 \mathrm{~B} 302$ & NA & Water & Field Blank & Set 1 \\
\hline NA & $552 \mathrm{~B} 304$ & NA & Water & Trip Blank & Total VOCs \\
\hline NA & $552 \mathrm{~B} 305$ & NA & Water & Trip Blank & Total VOCs \\
\hline NA & $552 \mathrm{~B} 306$ & NA & Water & Trip Blank & Total VOCs \\
\hline NA & $552 \mathrm{~B} 307$ & NA & Water & Trip Blank & Total VOCs \\
\hline NA & $552 \mathrm{~B} 308$ & NA & Water & Trip Blank & Total VOCs \\
\hline NA & $552 \mathrm{~B} 309$ & NA & Water & Trip Blank & Total VOCs \\
\hline NA & $552 \mathrm{~B} 310$ & NA & Water & Field Blank & Set 1 \\
\hline NA & $552 \mathrm{~B} 311$ & NA & Water & Equipment Rinsate Blank & Set 1 \\
\hline NA & $552 \mathrm{~B} 312$ & NA & Water & Trip Blank & Total VOCs \\
\hline NA & $552 \mathrm{~B} 313$ & NA & Water & Trip Blank & Total VOCs \\
\hline
\end{tabular}

Set 1 = Total VOCs, Total SVOCs, RCRA Metals, TPH (DRO and GRO), PCBs, Gamma Spectroscopy, Isotopic Uranium, Isotopic Plutonium, Strontium-90

$\mathrm{ft}$ bgs $=$ Feet below ground surface MS/MSD = Matrix spike/matrix spike duplicate NA $=$ Not applicable

Surface soil samples were collected from 0.0 to $0.5 \mathrm{ft}$ bgs or 0.0 to $1.0 \mathrm{ft}$ bgs. Most surface soil samples were collected using grab sampling techniques. Biased locations focused on stained soil, areas of low topography, or areas with elevated radiological measurements. Random locations at which pond sediment existed were sampled at a random depth within the sediment and at the sediment/native soil interface. 


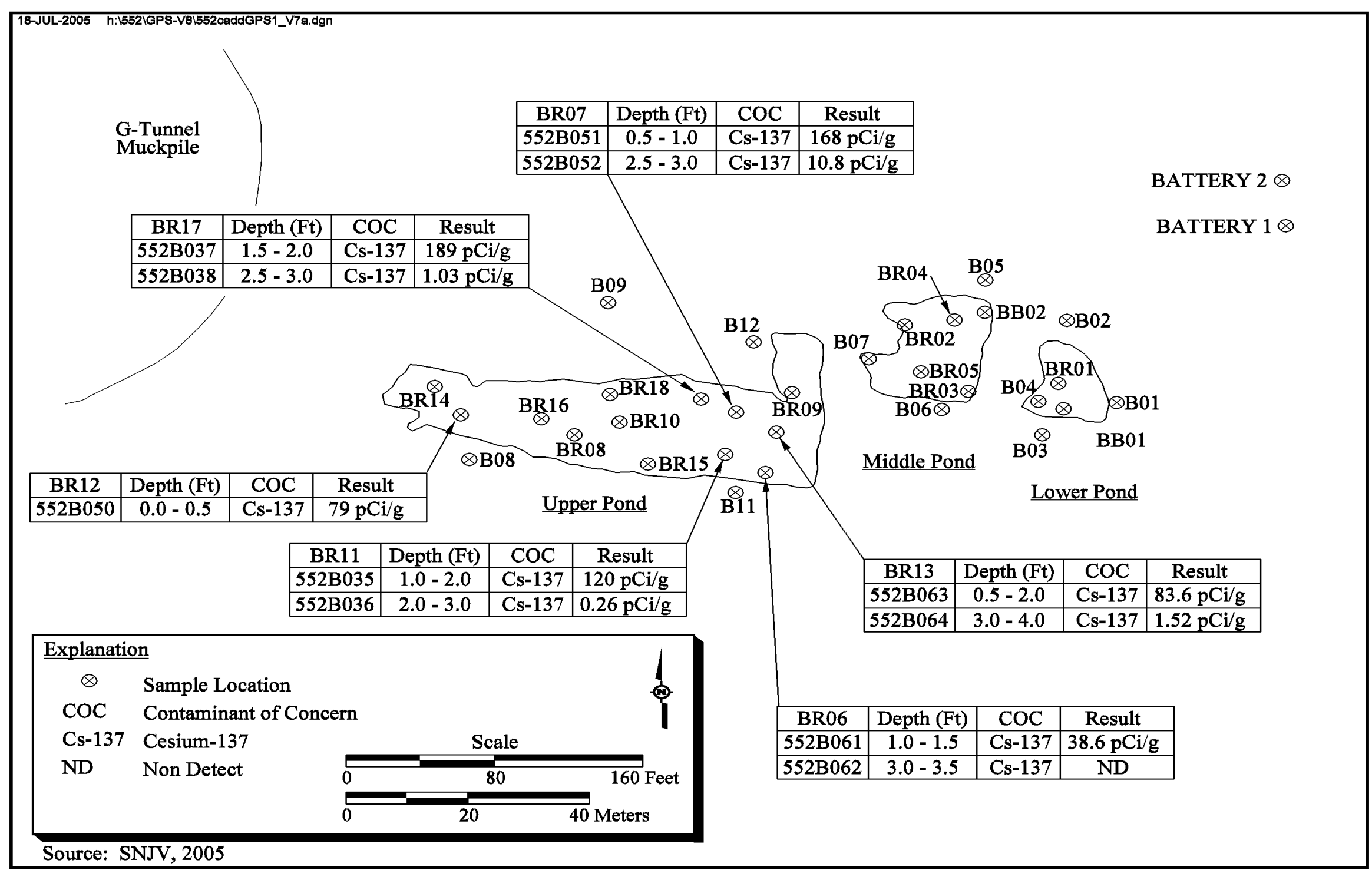

Figure A.2-1

Sample Location Map, CAS 12-23-05, Ponds 


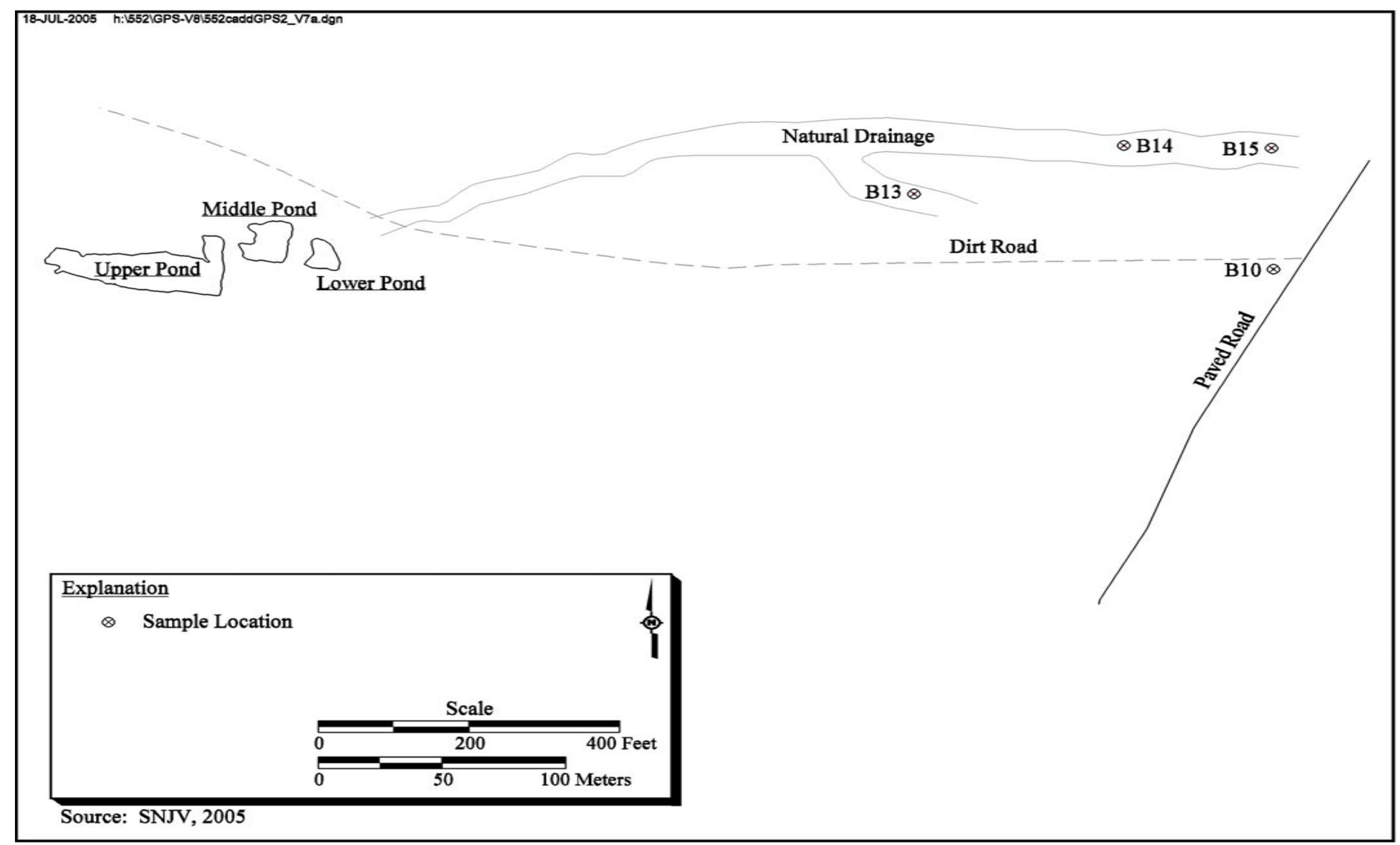

Figure A.2-2

Drainage Sample Location Map, CAS 12-23-05, Ponds 
Subsurface soil samples were collected from various depth intervals ranging from 1 to $2 \mathrm{ft}$ bgs up to and including 8 to $9 \mathrm{ft}$ bgs at selected sample locations using rotosonic drilling and hand augering techniques. Some selected soil samples with FSRs exceeding FSLs were also collected and submitted for off-site laboratory analysis.

Decision I sampling activities included the collection of surface and subsurface soil samples from each pond and their surrounding berms. If sediment was found to be present, subsurface samples were collected at the interface between the native soil and the overlying sediments. Subsurface berm samples were collected at the same depth as the identified sediment/native soil interface. No obvious release of contaminants was observed. Samples were also collected beneath two batteries located to the north of the lower pond (the pond furthest to the east, furthest from the muckpile). Samples were collected from the area to the east of the ponds that was identified as being naturally occurring storm drainage around the ponds and muckpile.

Samples were collected as outlined in the CAU 552 CAIP (NNSA/NSO, 2005) and submitted for laboratory analysis.

\section{A.2.2.4.1 Waste Characterization and Sampling}

Waste characterization activities were intended to gather adequate information and data about the CAU to support decisions regarding the disposal of materials located within the CAU.

Samples were analyzed in accordance with the procedures specified in the CAU 552 CAIP. The specific analyses are listed in Table A.2-2 and the analytical results are compared to the federal limits for hazardous waste, NDEP hydrocarbon action limit, landfill acceptance criteria, and the limits in the NTS performance objective criteria (POC) (BN, 1995). The POC limits have been established for NTS hazardous waste generators to ensure that all hazardous waste being shipped off-site contains no "added radioactivity."

\section{A.2.2.4.2 Sample Location Documentation}

A GPS instrument was used for determining the sample location coordinates as well as CAS points of interest. Appendix D presents this data in both tabular and graphic forms. 


\section{A.2.3 Laboratory Analytical Information}

Chemical and radiological analyses were performed by EMAX Laboratories, Inc., of Torrance, California, and Paragon Analytics, Inc., of Fort Collins, Colorado, respectively. The analytical parameters and laboratory analytical methods used to analyze investigation samples are listed in Table A.2-3. Organic and inorganic analytical results are reported in this appendix if they were detected at or above the minimum reporting levels (MRLs) established in Table 3-2 of the CAU 552 CAIP (NNSA/NSO, 2005). Radionuclide analytical results are reported in this appendix if they are detected at or above minimum detectable concentrations (MDCs).

Table A.2-3

\section{Laboratory Analytical Parameters and Methods, CAU 522 Investigation Samples}

\begin{tabular}{|c|c|}
\hline Analytical Parameter & Analytical Method \\
\hline Total volatile organic compounds & SW-846 8260B ${ }^{a}$ \\
\hline Total semivolatile organic compounds & SW-846 $8270 C^{a}$ \\
\hline Total petroleum hydrocarbons - gasoline-range organics & \multirow{2}{*}{ SW-846 8015B (modified) ${ }^{\mathrm{a}}$} \\
\hline Total petroleum hydrocarbons - diesel-range organics & \\
\hline Polychlorinated biphenyls & SW-846 8082 \\
\hline $\begin{array}{l}\text { Total Resource Conservation and Recovery Act (RCRA) } \\
\text { metals }^{\mathrm{b}}\end{array}$ & \multirow{2}{*}{$\begin{array}{l}\text { Water - SW-846 6010B/7470A } \\
\text { Soil - SW-846 6010B/7471A }\end{array}$} \\
\hline Total beryllium & \\
\hline Gamma-emitting radionuclides & Water - EPA 901.1 Soil - HASL-300 \\
\hline Isotopic uranium & Water - ASTM D3972-02 Soil - ASTM C1000-02 \\
\hline Isotopic plutonium & Water - ASTM D3865-02 Soil - ASTM C1001-00 \\
\hline Strontium-90 & Water - ASTM D5811-00 Soil - HASL-300 \\
\hline
\end{tabular}

aU.S. Environmental Protection Agency (EPA), Test Methods for Evaluating Solid Waste, Physical/Chemical Methods, 3rd Edition, Parts 1-4, SW-846 CD ROM. Washington, DC. (EPA, 1996)

${ }^{\mathrm{b}}$ Arsenic, barium, cadmium, chromium, lead, mercury, selenium, and silver 
Validated analytical data for CAU 552 investigation samples have been compiled and evaluated to confirm the presence of contamination and define the extent of contamination, if present. The analytical results for CAS 12-23-05 are presented in Section A.3.0. The analytical results have been compared to MRLs or MDCs, as appropriate, and only those above MRLs or MDCs are included in CAS-specific tables. The complete laboratory data packages are available in the project files.

The analytical parameters are CAS-specific and were selected through the application of site process knowledge according to the EPA's Guidance for the Data Quality Objectives Process (EPA, 1994b). Samples collected during step-out sampling were only analyzed for the COPCs that exceeded FALs in the original samples. Bioassessment samples were not collected because FSRs and observations did not indicate the need to assess a biodegradation corrective action alternative.

\section{A.2.4 Comparison to Action Levels}

Chemicals and radionuclides detected in samples at concentrations greater than FALs are identified as COCs. If COCs are present, corrective action must be considered for the CAS. The FALs for the CAU 552 investigation are defined in Section 2.3.1.

Sample data that are equal to or greater than MRLs in the case of chemical contaminants and greater that MDCs in the case of radiological contaminants for CAS 12-23-05 are tabulated in Section A.3.0. Results that are equal to or greater than FALs (a subset of those that exceed MRLs or MDCs) are identified by bold text in the corresponding tables.

Nondetected results and results below MRLs or MDCs have been excluded to minimize the size of this document. However, the unedited dataset for CAU 552 is retained in an electronic format in the project files.

\section{A.2.5 Geology}

Regional native surface soil consists of unconsolidated to moderately cemented boulders, cobbles, pebbles, and sand. Surface soil within the upper pond is sediment that was deposited during the period of time over which the ponds were used. The middle and lower ponds contained essentially no sediment, and the surface soil appeared as native. The sediment in the upper pond varied from approximately 2 to $4 \mathrm{ft}$ in thickness, although specific sampling locations at elevated locations within 
the pond indicated no sediment at the surface. Subsurface soil ranged from gravelly sands with fines to well-graded sands. The percentage of organic matter in the soil is low and decreases with depth beyond the native soil interface.

A general field description for each sample was recorded on SCLs. A more detailed description of the regional geology for the NTS is provided in the CAU 552 CAIP (NNSA/NSO, 2005).

\section{A.2.6 Hydrology}

No saturated zones (e.g., perched water, contaminant saturation) were found anywhere in the subsurface adjacent to or below the CASs, nor were saturated intervals identified during sampling activities.

\section{A.2.7 Deviations}

There were no significant deviations to the CAIP requirements at this CAS. However, rain and snow precipitation and accompanying snowmelt resulted in the presence of water in the lower depression of the upper pond (the pond closest to the muckpile), covering three of the proposed random locations. Samples were collected as close as possible to the water within the upper pond, and a sample of the water was also collected. After the water had evaporated, samples were collected from the proposed random locations. Samples were collected from beneath two batteries found adjacent to the lower pond. Weather conditions prevented the operation of the FID for VOC field-screening for one day of sampling. Some samples were too moist for radiological screening but enough sample was collected to perform analysis by gamma spectroscopy. All samples submitted to the laboratory from this CAS were requested to be analyzed for the parameters specified in the CAU 552 CAIP (NNSA/NSO, 2005). The investigation and sampling at CAS 12-23-05 is considered sufficient to meet the DQOs. The CAIP requirements were met at this CAS. 


\section{A.2.8 Investigation Results}

The following sections provide analytical results from the samples collected to complete investigation activities as outlined in the CAIP. Investigation samples were analyzed for the CAIP-specified COPCs, which included total VOCs, total SVOCs, TPH (DRO and GRO), total RCRA metals and beryllium, PCBs, and gamma-emitting radionuclides. Table A.2-2 lists the sample-specific analytical suite for CAS 12-23-05. The analytical parameters and laboratory methods used to analyze the investigation samples are listed in Table A.2-3.

Analytical results from the soil samples with concentrations exceeding MRLs or MDCs are summarized in the following sections. Results greater than FALs are identified by bold text in the analytical tables.

\section{A.2.8.1 Total Volatile Organic Compounds}

Total VOCs analytical results for soil samples collected from CAS 12-23-05, which were detected above MRLs, are presented in Table A.2-4. No VOCs were detected in soil samples above FALs.

\section{A.2.8.2 Total Semivolatile Organic Compounds}

No SVOCs in soil samples collected from CAS 12-23-05 exceeded the MRLs.

\section{A.2.8.3 Total Metals and Beryllium}

Total metal and beryllium analytical results for soil samples collected from CAS 12-23-05, which were detected above MRLs, are presented in Table A.2-5. No metals were detected in soil samples above FALs.

\section{A.2.8.4 Polychlorinated Biphenyls}

No PCBs in soil samples collected from CAS 12-23-05 exceeded the MRLs or FALs.

\section{A.2.8.5 Total Petroleum Hydrocarbons}

Total petroleum hydrocarbons (DRO and GRO) analytical results for soil samples collected from CAS 12-23-05, which were detected above MRLs, are presented in Table A.2-6. Total petroleum 
Table A.2-4

Soil Sample Results for Total VOCs Detected Above Minimum Reporting Limits at CAS 12-23-05

\begin{tabular}{|c|c|c|c|c|c|}
\hline \multirow{2}{*}{$\begin{array}{l}\text { Sample } \\
\text { Location }\end{array}$} & \multirow{2}{*}{$\begin{array}{l}\text { Sample } \\
\text { Number }\end{array}$} & \multirow{2}{*}{$\begin{array}{l}\text { Depth } \\
\text { (ft bgs) }\end{array}$} & \multicolumn{3}{|c|}{ Contaminants of Potential Concern $(\mu \mathrm{g} / \mathrm{kg})$} \\
\hline & & & Acetone & Methylene Chloride & Total Xylenes \\
\hline \multicolumn{3}{|c|}{ Final Action Levels ${ }^{a}$} & $6,000,000$ & 21,000 & 420,000 \\
\hline \multirow{2}{*}{ B01 } & 552B015 & $0.0-1.0$ & 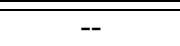 & $3.1(\mathrm{~J})$ & 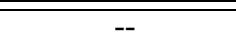 \\
\hline & 552B025 & $5.0-6.0$ & -- & $3.5(\mathrm{~J})$ & -- \\
\hline B05 & $552 \mathrm{~B} 026$ & $6.0-7.0$ & $13(\mathrm{~J})$ & $4.1(\mathrm{~J})$ & -- \\
\hline B06 & 552B027 & $4.5-5.0$ & -- & $3.9(\mathrm{~J})$ & -- \\
\hline \multirow{2}{*}{ B03 } & 552B004 & $0.0-0.5$ & -- & $3.8(\mathrm{~J})$ & -- \\
\hline & $552 \mathrm{~B} 024$ & $6.0-7.0$ & -- & $3.6(\mathrm{~J})$ & -- \\
\hline B09 & 552B010 & $0.0-0.5$ & -- & $3(\mathrm{~J})$ & -- \\
\hline B10 & 552B011 & $0.0-0.5$ & -- & -- & $9.4(\mathrm{~J})$ \\
\hline B14 & $552 \mathrm{~B} 059$ & $0.0-0.5$ & -- & $3.1(\mathrm{~J})^{\mathrm{b}}$ & -- \\
\hline BR02 & 552B028 & $0.0-0.5$ & -- & $3.7(\mathrm{~J})$ & -- \\
\hline BR03 & 552B029 & $0.0-0.5$ & -- & $3.1(\mathrm{~J})$ & -- \\
\hline BR04 & 552B030 & $0.0-0.5$ & -- & $3.3(\mathrm{~J})$ & -- \\
\hline
\end{tabular}

aBased on U.S. Environmental Protection Agency, Region 9 Preliminary Remediation Goals (PRGs) (EPA, 2002) ${ }^{b}$ Qualifier added to laboratory data; record accepted. Matrix effects may exist. Internal standard area count exceeds control limits. Surrogate recovery exceeded the upper limits.

$\mathrm{ft}$ bgs $=$ Feet below ground surface

$\mu \mathrm{g} / \mathrm{kg}=$ Micrograms per kilogram

$\mathrm{J}=$ Estimated value.

-- = Not detected above minimum reporting limits.

hydrocarbons-DRO were found above the FALs in seven samples. A Tier II evaluation show the hazardous constituents of TPH-DRO are below their corresponding PALs.

\section{A.2.8.6 Gamma-Emitting Radionuclides}

Gamma-emitting radionuclide analytical results for soil samples collected at CAS 12-23-05 detected above MDCs are presented in Table A.2-8. Cesium-137 was detected above the FALs in six samples, with concentrations ranging from 38.6 to $189 \mathrm{pCi} / \mathrm{g}$. All six samples were collected from sample locations within the upper pond. 


\section{A.2.8.7 Specific Isotopic Analysis}

Analytical results for isotopic plutonium, isotopic uranium and isotopic strontium in soil samples collected at CAS 12-23-05 detected above MDCs are presented in Table A.2-8.

\section{A.2.9 Nature and Extent of Contamination}

Cesium-137 contamination was found in six samples within the upper pond, including five sediment samples and one native soil surface sample. Because the sediment samples were part of the random sampling scheme outlined in the CAIP, the entire volume of sediment within the pond must be assumed to be contaminated with Cs-137. Native soil samples collected directly below the contaminated sediment were found to be free of contamination demonstrating no vertical migration of contaminants. No contamination was found in any samples outside of the upper pond demonstrating no lateral migration of contaminants. The extent of contamination at CAU 552 has been defined as the soil/sediment within the upper pond.

\section{A.2.10 Revised Conceptual Site Model}

No variations in the CSM were identified. 
Table A.2-5

Soil Sample Results for Metals Detected Above Minimum Reporting Limits at CAS 12-23-05 (Page 1 of 3 )

\begin{tabular}{|c|c|c|c|c|c|c|c|c|c|c|}
\hline \multirow[b]{2}{*}{$\begin{array}{c}\text { Sample } \\
\text { Location }\end{array}$} & \multirow[b]{2}{*}{$\begin{array}{l}\text { Sample } \\
\text { Number }\end{array}$} & \multirow[b]{2}{*}{$\begin{array}{c}\text { Depth } \\
\text { (ft bgs) }\end{array}$} & \multicolumn{8}{|c|}{ Contaminants of Concern (mg/kg) } \\
\hline & & & 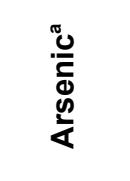 & $\begin{array}{l}\text { ह } \\
\text { 를 } \\
\text { m } \\
\text { m }\end{array}$ & 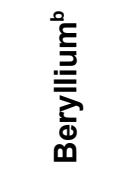 & 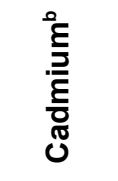 & 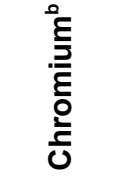 & 임 & $\begin{array}{l}\stackrel{0}{3} \\
\frac{0}{3} \\
\sum\end{array}$ & 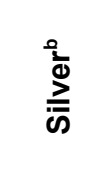 \\
\hline \multicolumn{3}{|c|}{ Final Action Levels } & 23 & 67,000 & 1,900 & 450 & 450 & 750 & 310 & 5,100 \\
\hline \multirow{3}{*}{ B01 } & 552B001 & $0.0-0.5$ & 1.05 & 62.8 & 0.655 & -- & 1.38 & 6.04 & & - \\
\hline & 552B015 & $0.0-1.0$ & $1.25(\mathrm{~J}-)^{\mathrm{c}}$ & 101 & 1.58 & -- & 1.3 & 8.14 & & -- \\
\hline & 552B025 & $5.0-6.0$ & 1.17 & $66.5(J)^{c}$ & 0.66 & $0.119(\mathrm{~J})$ & -- & $6.32(J)^{c}$ & $0.040(\mathrm{~J})$ & - \\
\hline \multirow{4}{*}{ B02 } & 552B002 & $0.0-0.5$ & $0.983(\mathrm{~J})$ & 67.9 & 0.684 & -- & 1.41 & 6.26 & & - \\
\hline & 552B003 & $0.0-0.5$ & 1.14 & 66 & 0.615 & -- & 1.22 & 5.19 & & -- \\
\hline & 552B012 & $0.0-1.0$ & $0.829(\mathrm{~J}-)$ & 70.2 & 0.707 & -- & $0.943(\mathrm{~J})$ & 5.94 & & -- \\
\hline & 552B013 & $5.0-6.0$ & $1.06(\mathrm{~J}-)^{\mathrm{c}}$ & 62.9 & 0.694 & -- & 1.6 & 8.34 & & -- \\
\hline \multirow{2}{*}{ B03 } & 552B004 & $0.0-0.5$ & 1.23 & 67.5 & 0.697 & - & 1.57 & 6.33 & & -- \\
\hline & 552B024 & $6.0-7.0$ & 2.3 & $86.5(\mathrm{~J})^{\mathrm{c}}$ & 0.854 & -- & -- & $23.9(\mathrm{~J})^{\mathrm{c}}$ & & -- \\
\hline \multirow{2}{*}{ B04 } & 552B005 & $0.0-0.5$ & $1.02(\mathrm{~J}-)^{\mathrm{c}}$ & 67.5 & 0.776 & -- & 1.16 & 6 & & -- \\
\hline & 552B017 & $0.0-1.0$ & $1.07(\mathrm{~J}-)^{\mathrm{c}}$ & 56.8 & 0.628 & -- & 1.28 & 4.79 & & -- \\
\hline \multirow{4}{*}{ B05 } & 552B006 & $0.0-0.5$ & $1.1(\mathrm{~J}-)^{\mathrm{C}}$ & 52.3 & $0.491(\mathrm{~J})$ & -- & 1.3 & 6.63 & & -- \\
\hline & 552B018 & $0.0-1.0$ & $0.944(\mathrm{~J}-)$ & 53.6 & $0.562(J)^{c}$ & -- & $0.918(\mathrm{~J})$ & 4.97 & & -- \\
\hline & 552B019 & $8.0-9.0$ & $1.96(\mathrm{~J}-)^{\mathrm{c}}$ & 68 & 0.922 & -- & 2.39 & 7.17 & & -- \\
\hline & 552B026 & $6.0-7.0$ & 1.36 & $51.8(\mathrm{~J})^{\mathrm{c}}$ & 0.602 & -- & -- & $4.52(J)^{c}$ & & -- \\
\hline \multirow{2}{*}{ B06 } & 552B007 & $0.0-0.5$ & $1.03(\mathrm{~J}-)^{\mathrm{c}}$ & 59.9 & 0.628 & -- & 1.61 & 5.43 & & -- \\
\hline & 552B027 & $4.5-5.0$ & 1.68 & $64.7(\mathrm{~J})^{\mathrm{c}}$ & 0.779 & $0.127(\mathrm{~J})$ & -- & $6.11(\mathrm{~J})^{\mathrm{c}}$ & & - \\
\hline \multirow{2}{*}{ B07 } & 552B008 & $0.0-0.5$ & $0.864(\mathrm{~J}-)$ & 61.2 & $0.507(J)^{c}$ & -- & 1.73 & 5.83 & & -- \\
\hline & 552B034 & $2.0-3.0$ & 1.31 & $57.2(\mathrm{~J})^{\mathrm{c}}$ & 0.712 & -- & -- & $4.89(\mathrm{~J})^{\mathrm{c}}$ & & -- \\
\hline B08 & 552B009 & $0.0-0.5$ & $1.01(\mathrm{~J}-)^{\mathrm{c}}$ & 93.9 & 0.677 & -- & 1.5 & 10.5 & & -- \\
\hline B09 & 552B010 & $0.0-0.5$ & $1.17(\mathrm{~J}-)^{\mathrm{c}}$ & 73.6 & 0.744 & -- & 1.69 & 5.9 & & -- \\
\hline B10 & 552B011 & $0.0-0.5$ & 1.86 & 126 & 0.809 & -- & 2.2 & $8.36(J)^{d}$ & & -- \\
\hline \multirow{2}{*}{ B11 } & 552B054 & $0.0-0.5$ & 1.39 & 87.5 & 0.716 & -- & 1.48 & 7.37 & & -- \\
\hline & 552B055 & $4.0-4.5$ & 2.16 & 335 & 0.976 & $0.129(\mathrm{~J})$ & 1.4 & 54.8 & & -- \\
\hline \multirow{2}{*}{ B12 } & 552B056 & $0.0-0.5$ & 1.69 & 64.7 & 0.627 & -- & $0.668(\mathrm{~J})$ & 6.17 & & $0.474(\mathrm{~J})$ \\
\hline & 552B057 & $4.0-4.5$ & 1.41 & 75.3 & 0.687 & -- & $0.775(\mathrm{~J})$ & 11.4 & & -- \\
\hline B13 & 552B058 & $0.0-0.5$ & 2.23 & 113 & 0.98 & $0.127(\mathrm{~J})$ & 2.04 & 12.6 & & -- \\
\hline
\end{tabular}


Table A.2-5

Soil Sample Results for Metals Detected Above Minimum Reporting Limits at CAS 12-23-05 (Page 2 of 3 )

\begin{tabular}{|c|c|c|c|c|c|c|c|c|c|c|}
\hline \multirow[b]{2}{*}{$\begin{array}{l}\text { Sample } \\
\text { Location }\end{array}$} & \multirow[b]{2}{*}{$\begin{array}{l}\text { Sample } \\
\text { Number }\end{array}$} & \multirow[b]{2}{*}{$\begin{array}{c}\text { Depth } \\
\text { (ft bgs) }\end{array}$} & \multicolumn{8}{|c|}{ Contaminants of Concern (mg/kg) } \\
\hline & & & $\begin{array}{l}\frac{\pi}{0} \\
\frac{0}{0} \\
0 \\
\frac{0}{4}\end{array}$ & 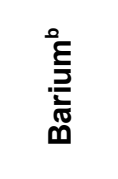 & 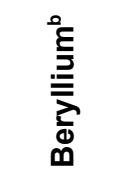 & 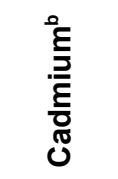 & 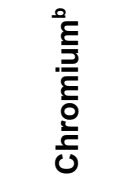 & 욣 & $\begin{array}{l}\stackrel{0}{3} \\
\frac{0}{0} \\
\sum\end{array}$ & $\frac{2}{\frac{2}{\infty}}$ \\
\hline \multicolumn{3}{|c|}{ Final Action Levels } & 23 & 67,000 & 1,900 & 450 & 450 & 750 & 310 & 5,100 \\
\hline B14 & 552B059 & $0.0-0.5$ & 1.53 & 84.3 & 0.733 & $0.16(J)$ & 1.47 & 9.08 & -- & $0.411(\mathrm{~J})$ \\
\hline B15 & 552В060 & $0.0-0.5$ & 2.1 & 106 & 0.949 & $0.135(\mathrm{~J})$ & 2.43 & 13 & -- & -- \\
\hline \multirow{2}{*}{ BB01 } & 552B016 & $1.0-2.0$ & $1.51(\mathrm{~J}-)^{\mathrm{c}}$ & 82.8 & 0.916 & -- & 1.68 & 8.54 & -- & -- \\
\hline & $552 \mathrm{~B} 021$ & $4.0-5.0$ & 2.04 & 120 & 0.917 & & 2.38 & 12 & -- & -- \\
\hline \multirow[t]{2}{*}{ BB02 } & 552B032 & $0.0-0.5$ & 2.23 & $103(J)^{c}$ & 1.3 & $0.182(\mathrm{~J})$ & 2.47 & $11.5(J)^{\mathrm{c}}$ & -- & -- \\
\hline & 552B033 & $2.0-3.0$ & 2.11 & $87.1(J)^{\mathrm{c}}$ & 0.913 & -- & -- & $9.39(\mathrm{~J})^{\mathrm{c}}$ & -- & -- \\
\hline \multirow{2}{*}{ BR01 } & 552B014 & $0.0-1.0$ & $1.09(\mathrm{~J}-)^{\mathrm{c}}$ & 199 & 0.702 & -- & 2.69 & 22.7 & -- & -- \\
\hline & 552B020 & $4.0-5.0$ & 2.6 & 74.8 & 0.731 & & & 6.63 & -- & -- \\
\hline BR02 & 552B028 & $0.0-0.5$ & $1.09(\mathrm{~J})^{\mathrm{c}}$ & $62.8(J)^{\mathrm{c}}$ & $0.558(J)^{c}$ & -- & -- & $5.07(\mathrm{~J})^{\mathrm{c}}$ & -- & -- \\
\hline BR03 & 552B029 & $0.0-0.5$ & 1.25 & $82.9(J)^{c}$ & 0.722 & -- & -- & $6.19(\mathrm{~J})^{\mathrm{c}}$ & -- & -- \\
\hline \multirow{2}{*}{ BR04 } & 552B030 & $0.0-0.5$ & $1.08(\mathrm{~J})^{\mathrm{c}}$ & $73.3(\mathrm{~J})^{\mathrm{c}}$ & 0.614 & - & - & $6.55(J)^{c}$ & -- & -- \\
\hline & 552B022 & $4.0-5.0$ & 1.72 & 109 & 0.795 & -- & -- & 12.3 & -- & -- \\
\hline BR05 & 552B031 & $0.0-0.5$ & 3.06 & $66.7(\mathrm{~J})^{\mathrm{c}}$ & 0.728 & -- & -- & $13(\mathrm{~J})^{\mathrm{c}}$ & -- & -- \\
\hline \multirow{2}{*}{ BR06 } & 552B061 & $1.0-1.5$ & $2.11(\mathrm{~J}+)$ & 402 & 1.29 & $0.149(\mathrm{~J})$ & 2.1 & 13.7 & -- & $0.338(\mathrm{~J})$ \\
\hline & 552B062 & $3.0-3.5$ & $1.61(\mathrm{~J}+)$ & 86.6 & 0.559 & -- & $0.59(\mathrm{~J})$ & 9.05 & -- & -- \\
\hline \multirow{4}{*}{ BR07 } & 552B051 & $0.5-1.0$ & 3.38 & 566 & 2.4 & $0.407(\mathrm{~J})$ & 1.77 & 37.3 & -- & $1.05(\mathrm{~J})^{\mathrm{c}}$ \\
\hline & 552B052 & $2.5-3.0$ & 1.95 & 107 & 1.14 & $0.219(\mathrm{~J})$ & 1.26 & 7.84 & -- & -- \\
\hline & 552B066 & $1.0-1.5$ & $1.37(\mathrm{~J}+)$ & 143 & 0.888 & -- & 1.53 & 8.25 & -- & -- \\
\hline & 552B067 & $3.0-3.5$ & $0.832(\mathrm{~J}+)$ & 58.2 & $0.551(\mathrm{~J})$ & -- & 1.14 & 5.91 & -- & -- \\
\hline \multirow{3}{*}{ BR08 } & 552B043 & $0.0-1.0$ & 2.08 & $246(J)^{c}$ & 1.39 & -- & -- & $11.8(\mathrm{~J})^{\mathrm{e}}$ & - & $0.851(\mathrm{~J}-)$ \\
\hline & 552B044 & $1.0-2.0$ & 1.4 & $93.2(J)^{c}$ & 0.888 & $0.19(\mathrm{~J})$ & 2.2 & $15.3(J)^{e}$ & -- & $0.472(\mathrm{~J}-)$ \\
\hline & 552B045 & $1.0-2.0$ & 1.43 & $87.5(J)^{c}$ & 0.919 & $0.174(\mathrm{~J})$ & 1.65 & $5.62(J)^{\mathrm{e}}$ & - & $0.508(\mathrm{~J}-)$ \\
\hline BR10 & 552B040 & $0.0-1.0$ & 1.75 & $167(J)^{c}$ & 0.811 & $0.131(\mathrm{~J})$ & -- & $10.3(J)^{c}$ & -- & - \\
\hline \multirow{2}{*}{ BR11 } & 552B035 & $1.0-2.0$ & 3.43 & $922(J)^{c}$ & 2.16 & $0.393(\mathrm{~J})$ & - & $32.4(J)^{c}$ & -- & -- \\
\hline & 552B036 & $2.0-3.0$ & 1.73 & $74.2(\mathrm{~J})^{\mathrm{c}}$ & 0.792 & -- & -- & $7.49(\mathrm{~J})^{\mathrm{c}}$ & -- & -- \\
\hline BR12 & 552B050 & $0.0-0.5$ & 2.65 & 250 & 0.941 & $0.172(\mathrm{~J})$ & $0.878(\mathrm{~J})$ & 23.7 & -- & -- \\
\hline
\end{tabular}




\section{Table A.2-5 \\ Soil Sample Results for Metals Detected \\ Above Minimum Reporting Limits at CAS 12-23-05}

(Page 3 of 3 )

\begin{tabular}{|c|c|c|c|c|c|c|c|c|c|c|}
\hline \multirow[b]{2}{*}{$\begin{array}{l}\text { Sample } \\
\text { Location }\end{array}$} & \multirow[b]{2}{*}{$\begin{array}{l}\text { Sample } \\
\text { Number }\end{array}$} & \multirow[b]{2}{*}{$\begin{array}{c}\text { Depth } \\
\text { (ft bgs) }\end{array}$} & \multicolumn{8}{|c|}{ Contaminants of Concern $(\mathrm{mg} / \mathrm{kg})$} \\
\hline & & & 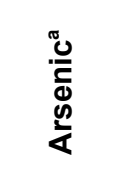 & 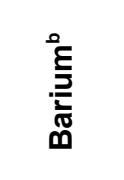 & 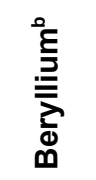 & 를 & 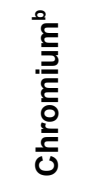 & 兽 & 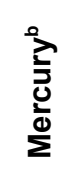 & 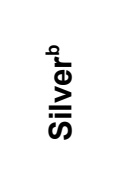 \\
\hline \multicolumn{3}{|c|}{ Final Action Levels } & 23 & 67,000 & 1,900 & 450 & 450 & 750 & 310 & 5,100 \\
\hline \multirow{3}{*}{ BR13 } & 552B063 & $0.5-2.0$ & 2.97 & 530 & 1.93 & $0.201(J)$ & 2.6 & 28.6 & -- & $0.403(\mathrm{~J})$ \\
\hline & 552B064 & $3.0-4.0$ & $1.4(\mathrm{~J}+)$ & 126 & 0.648 & -- & $1.02(\mathrm{~J})$ & 7.01 & -- & -- \\
\hline & 552B065 & $3.0-4.0$ & $1.69(\mathrm{~J}+)$ & 199 & 0.632 & -- & 1.16 & 26.7 & -- & -- \\
\hline BR14 & 552B047 & $0.5-1.0$ & 1.27 & $70.1(\mathrm{~J})^{\mathrm{c}}$ & 0.781 & $0.121(J)$ & -- & $5.98(\mathrm{~J})^{\mathrm{e}}$ & -- & -- \\
\hline BR15 & 552B039 & $0.0-1.0$ & $1.12(J)^{c}$ & $123(\mathrm{~J})^{\mathrm{c}}$ & 0.81 & -- & -- & $6.55(\mathrm{~J})^{\mathrm{c}}$ & -- & -- \\
\hline BR16 & 552B046 & $0.5-1.0$ & 2.07 & $73.8(\mathrm{~J})^{\mathrm{c}}$ & 0.852 & $0.183(\mathrm{~J})$ & -- & $16(J)^{\mathrm{e}}$ & -- & $0.315(\mathrm{~J}-)$ \\
\hline \multirow{2}{*}{ BR17 } & 552B037 & $1.5-2.0$ & 2.04 & $797(\mathrm{~J})^{\mathrm{C}}$ & 1.44 & $0.624(J)^{c}$ & -- & $45.6(J)^{c}$ & -- & -- \\
\hline & 552B038 & $2.5-3.0$ & 1.3 & $81.5(\mathrm{~J})^{\mathrm{C}}$ & 0.721 & -- & -- & $6.91(\mathrm{~J})^{\mathrm{c}}$ & -- & -- \\
\hline \multirow{2}{*}{ BR18 } & 552B041 & $0.0-1.0$ & 1.69 & $170(\mathrm{~J})^{\mathrm{c}}$ & 1.1 & 0.142 & -- & $7.24(\mathrm{~J})^{\mathrm{c}}$ & -- & -- \\
\hline & 552B042 & $2.0-2.5$ & $1.13(\mathrm{~J})^{\mathrm{c}}$ & $73.9(\mathrm{~J})^{\mathrm{c}}$ & 0.715 & -- & -- & $5(\mathrm{~J})^{\mathrm{c}}$ & -- & -- \\
\hline B Battery 1 & 552B048 & $0.0-0.5$ & 1.92 & 78.4 & 0.883 & $0.29(\mathrm{~J})$ & 1.99 & 229 & -- & -- \\
\hline B Battery 2 & 552B049 & $0.0-0.5$ & 1.52 & 88.4 & 0.716 & $0.595(\mathrm{~J})$ & 1.55 & 29.4 & -- & $0.49(\mathrm{~J})$ \\
\hline
\end{tabular}

\footnotetext{
aBased on the background concentrations for metals. Background is considered the mean plus two times the standard deviation for sediment samples collected by the Nevada Bureau of Mines and Geology throughout the Nevada Test and Training Range (NBMG, 1998; Moore, 1999). ${ }^{b}$ Based on U.S. Environmental Protection Agency, Region 9 Preliminary Remediation Goals (PRGs) (EPA, 2002)

${ }^{\circ} Q u a l i f i e r$ added to laboratory data; record accepted. Matrix spike recovery exceeds control limits.

${ }^{d}$ Qualifier added to laboratory data; record accepted. Serial dilution \%D exceeds control limits. Matrix effects may exist.

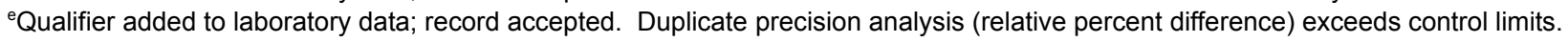

$\mathrm{ft}$ bgs $=$ Feet below ground surface

$\mathrm{mg} / \mathrm{kg}=$ Milligrams per kilogram

$\mathrm{J}=$ Estimate value.

$\mathrm{J}+=$ The result is an estimated quantity, but the result may be biased high. Contract required quantitation limit check standard recovery exceeds control limits.

$\mathrm{J}-=$ The result is an estimated quantity, but the result may be biased low. Negative bias found in continuing calibration/method blank.

$--=$ Not detected above minimum reporting limits.
} 
Table A.2-6

Soil Sample Results for TPH Detected

Above Minimum Reporting Limits at CAS 12-23-05

\begin{tabular}{|c|c|c|c|c|}
\hline \multirow{2}{*}{$\begin{array}{l}\text { Sample } \\
\text { Location }\end{array}$} & \multirow{2}{*}{$\begin{array}{l}\text { Sample } \\
\text { Number }\end{array}$} & \multirow{2}{*}{$\begin{array}{c}\text { Depth } \\
\text { (ft bgs) }\end{array}$} & \multicolumn{2}{|c|}{ Contaminants of Potential Concern $(\mathrm{mg} / \mathrm{kg})$} \\
\hline & & & \multirow{2}{*}{$\frac{\text { Diesel Range Organics }}{100}$} & Gasoline Range Organics \\
\hline \multicolumn{3}{|c|}{ Preliminary Action Levels ${ }^{a}$} & & 100 \\
\hline \multirow{2}{*}{ B01 } & 552B001 & $0.0-0.5$ & $8.6(\mathrm{~J})$ & -- \\
\hline & 552B015 & $0.0-1.0$ & 41 & -- \\
\hline \multirow{4}{*}{ B02 } & 552B002 & $0.0-0.5$ & $5.1(\mathrm{~J})$ & -- \\
\hline & 552B003 & $0.0-0.5$ & $8.4(\mathrm{~J})$ & -- \\
\hline & 552B012 & $0.0-1.0$ & 18 & -- \\
\hline & 552B013 & $5.0-6.0$ & 17 & -- \\
\hline B03 & 552B004 & $0.0-0.5$ & $6.8(\mathrm{~J})$ & -- \\
\hline B04 & 552B005 & $0.0-0.5$ & 12 & -- \\
\hline B09 & 552B010 & $0.0-0.5$ & $10(\mathrm{~J})$ & -- \\
\hline B11 & 552B054 & $0.0-0.5$ & 140 & -- \\
\hline B14 & 552B059 & $0.0-0.5$ & 150 & -- \\
\hline B15 & 552B060 & $0.0-0.5$ & 140 & -- \\
\hline BB01 & 552B016 & 1.0. - 2.0 & 16 & -- \\
\hline BB02 & 552B032 & $0.0-0.5$ & 90 & 1.9 \\
\hline BR01 & 552B014 & $0.0-1.0$ & 83 & -- \\
\hline BR03 & 552B029 & $0.0-0.5$ & 42 & -- \\
\hline BR07 & 552В052 & $2.5-3.0$ & 190 & -- \\
\hline BR10 & 552B040 & $0.0-1.0$ & 25 & 1.2 \\
\hline \multirow{2}{*}{ BR11 } & 552B035 & $1.0-2.0$ & 160 & -- \\
\hline & 552В036 & $2.0-3.0$ & 71 & -- \\
\hline BR13 & 552B064 & $3.0-4.0$ & 38 & -- \\
\hline B Battery 1 & 552B048 & $0.0-0.5$ & 230 & -- \\
\hline B Battery 2 & 552B049 & $0.0-0.5$ & 190 & -- \\
\hline
\end{tabular}

aBased on Nevada Administrative Code; Contamination of soil: Establishment of action levels (NAC, 2002)

$\mathrm{ft}$ bgs $=$ Feet below ground surface

$\mathrm{mg} / \mathrm{kg}=$ Milligrams per kilogram 
Table A.2-7

Soil Sample Results for Gamma-Emitting Radionuclides Detected Above Minimum Detectable Concentrations at CAS 12-23-05

(Page 1 of 6$)$

\begin{tabular}{|c|c|c|c|c|c|c|c|c|c|c|c|c|c|c|c|c|c|c|}
\hline \multirow[b]{2}{*}{$\begin{array}{c}\text { Sample } \\
\text { Location }\end{array}$} & \multirow[b]{2}{*}{$\begin{array}{l}\text { Sample } \\
\text { Number }\end{array}$} & \multirow{3}{*}{$\begin{array}{c}\text { Depth } \\
\text { (ft bgs) }\end{array}$} & \multicolumn{16}{|c|}{ Contaminants of Potential Concern (pCi/g) } \\
\hline & & & \multicolumn{2}{|c|}{ 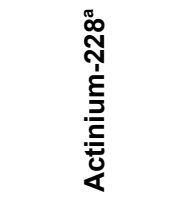 } & 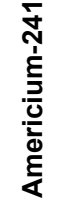 & \multicolumn{2}{|c|}{ 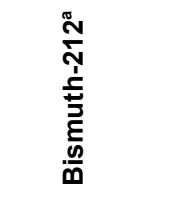 } & \multicolumn{2}{|c|}{ 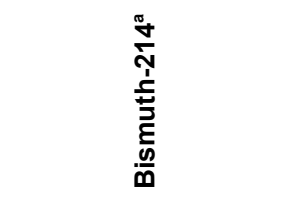 } & \multirow{3}{*}{ 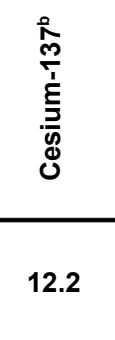 } & \multirow{3}{*}{$\begin{array}{l}8 \\
\frac{8}{1} \\
\frac{1}{\pi} \\
\frac{0}{0} \\
0\end{array}$} & \multicolumn{2}{|c|}{ 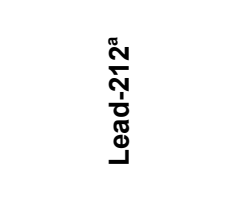 } & \multicolumn{2}{|c|}{ 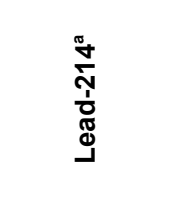 } & \multicolumn{2}{|c|}{ 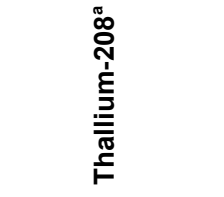 } & \multirow{3}{*}{ 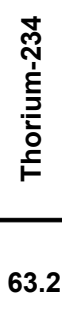 } \\
\hline \multicolumn{2}{|c|}{ Final Action Levels } & & 5 & 15 & \multirow{2}{*}{12.7} & 5 & 15 & 5 & 15 & & & 5 & 15 & 5 & 15 & 5 & 15 & \\
\hline \multicolumn{3}{|c|}{ Depth bgs (cm) } & $<15$ & $>15$ & & $<15$ & $>15$ & $<15$ & $>15$ & & & $<15$ & $>15$ & $<15$ & $>15$ & $<15$ & $>15$ & \\
\hline \multirow{3}{*}{ B01 } & 552B001 & $0.0-0.5$ & $\begin{array}{l}2.08 \\
(G)\end{array}$ & NA & -- & -- & NA & $1.41(\mathrm{G}, \mathrm{J})$ & NA & -- & -- & $2.33(\mathrm{~J})^{\mathrm{C}}$ & NA & $\begin{array}{l}1.26 \\
(G, J)\end{array}$ & NA & $\begin{array}{l}0.82 \\
(\mathrm{G})\end{array}$ & NA & -- \\
\hline & 552B015 & $0.0-1.0$ & NA & $\begin{array}{l}2.57 \\
(G)\end{array}$ & -- & NA & $\begin{array}{l}5.4 \\
(\mathrm{G})\end{array}$ & NA & $1.14(\mathrm{G}, \mathrm{J})$ & $5.55(\mathrm{G})$ & -- & NA & $3.01(\mathrm{~J})^{\mathrm{c}}$ & NA & $\begin{array}{c}1.4 \\
(G, J)\end{array}$ & NA & $\begin{array}{l}1.01 \\
(\mathrm{G})\end{array}$ & -- \\
\hline & 552B025 & $5.0-6.0$ & NA & $\begin{array}{c}2.43 \\
(G)\end{array}$ & -- & NA & -- & NA & $1.25(\mathrm{G}, \mathrm{J})$ & $1.97(\mathrm{G})$ & -- & NA & $2.42(\mathrm{~J})^{\mathrm{C}}$ & NA & $\begin{array}{c}1.32 \\
(G, J)\end{array}$ & NA & $0.9(\mathrm{G})$ & -- \\
\hline \multirow{4}{*}{ B02 } & 552B002 & $0.0-0.5$ & $\begin{array}{l}1.91 \\
(\mathrm{G})\end{array}$ & NA & - & -- & NA & $0.96(G, J)$ & NA & - & -- & $2.1(J)^{c}$ & NA & $\begin{array}{c}1.3(\mathrm{G}, \\
\mathrm{J})\end{array}$ & NA & $\begin{array}{l}0.63 \\
(\mathrm{G})\end{array}$ & NA & -- \\
\hline & 552B003 & $0.0-0.5$ & $\begin{array}{c}2.21 \\
(G)\end{array}$ & NA & - & -- & NA & $1(G, J)$ & NA & -- & -- & $2.27(\mathrm{~J})^{\mathrm{C}}$ & NA & $\begin{array}{l}1.19 \\
(G, J)\end{array}$ & NA & $\begin{array}{l}0.74 \\
(\mathrm{G})\end{array}$ & NA & -- \\
\hline & 552B012 & $0.0-1.0$ & $\begin{array}{c}2.22 \\
(G)\end{array}$ & NA & - & -- & NA & $1.05(\mathrm{G}, \mathrm{J})$ & NA & -- & -- & $2.68(\mathrm{~J})^{\mathrm{c}}$ & NA & $\begin{array}{l}1.49 \\
(G, J)\end{array}$ & NA & $\begin{array}{l}0.73 \\
(\mathrm{G})\end{array}$ & NA & -- \\
\hline & 552B013 & $5.0-6.0$ & NA & $\begin{array}{l}2.16 \\
(G)\end{array}$ & -- & NA & -- & NA & $1.3(\mathrm{G}, \mathrm{J})$ & -- & -- & NA & $2.47(\mathrm{~J})^{\mathrm{c}}$ & NA & $\begin{array}{c}1.11 \\
(G, J)\end{array}$ & NA & $\begin{array}{l}0.79 \\
(\mathrm{G})\end{array}$ & -- \\
\hline \multirow{2}{*}{ B03 } & 552B004 & $0.0-0.5$ & $\begin{array}{l}2.16 \\
(G)\end{array}$ & NA & -- & -- & NA & $1.26(\mathrm{G}, \mathrm{J})$ & NA & $0.87(\mathrm{G})$ & -- & $2.69(\mathrm{~J})^{\mathrm{C}}$ & NA & $\begin{array}{l}1.41 \\
(G, J)\end{array}$ & NA & $\begin{array}{l}0.72 \\
(\mathrm{G})\end{array}$ & NA & -- \\
\hline & 552B024 & $6.0-7.0$ & NA & $\begin{array}{l}2.22 \\
(G)\end{array}$ & -- & NA & -- & NA & $1.39(\mathrm{G}, \mathrm{J})$ & -- & -- & NA & $2.51(\mathrm{~J})^{\mathrm{c}}$ & NA & $\begin{array}{c}1.51 \\
(G, J)\end{array}$ & NA & $\begin{array}{l}0.83 \\
(G)\end{array}$ & -- \\
\hline \multirow{2}{*}{ B04 } & 552B005 & $0.0-0.5$ & $\begin{array}{l}2.27 \\
(\mathrm{G})\end{array}$ & NA & -- & -- & NA & $1.27(\mathrm{G}, \mathrm{J})$ & NA & $2.7(\mathrm{G})$ & -- & $2.57(\mathrm{~J})^{\mathrm{c}}$ & NA & $\begin{array}{l}1.31 \\
(G, J)\end{array}$ & NA & $0.7(\mathrm{G})$ & NA & -- \\
\hline & 552B017 & $0.0-1.0$ & NA & $\begin{array}{l}2.02 \\
(G)\end{array}$ & -- & NA & -- & NA & $1.37(\mathrm{G}, \mathrm{J})$ & $0.51(\mathrm{G})$ & -- & NA & $2.69(\mathrm{~J})^{\mathrm{c}}$ & NA & $\begin{array}{c}1.28 \\
(G, J)\end{array}$ & NA & $\begin{array}{l}0.74 \\
(G)\end{array}$ & -- \\
\hline
\end{tabular}


Table A.2-7

Soil Sample Results for Gamma-Emitting Radionuclides Detected Above Minimum Detectable Concentrations at CAS 12-23-05

(Page 2 of 6 )

\begin{tabular}{|c|c|c|c|c|c|c|c|c|c|c|c|c|c|c|c|c|c|c|}
\hline \multirow[b]{2}{*}{$\begin{array}{c}\text { Sample } \\
\text { Location }\end{array}$} & \multirow[b]{2}{*}{$\begin{array}{l}\text { Sample } \\
\text { Number }\end{array}$} & \multirow{3}{*}{$\begin{array}{c}\text { Depth } \\
\text { (ft bgs) }\end{array}$} & \multicolumn{16}{|c|}{ Contaminants of Potential Concern (pCi/g) } \\
\hline & & & \multicolumn{2}{|c|}{ 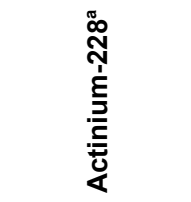 } & 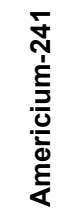 & \multicolumn{2}{|c|}{ 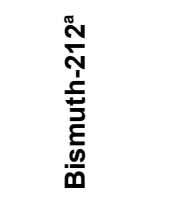 } & \multicolumn{2}{|c|}{ 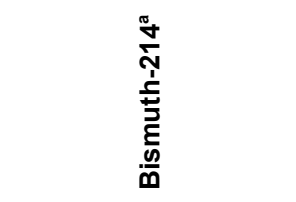 } & \multirow{3}{*}{ 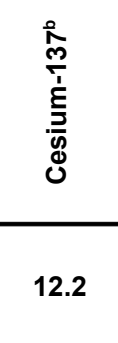 } & \multirow{3}{*}{$\begin{array}{l}8 \\
0 \\
\frac{1}{\pi} \\
\frac{1}{0} \\
0 \\
0\end{array}$} & \multicolumn{2}{|c|}{ 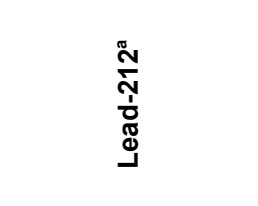 } & \multicolumn{2}{|c|}{ 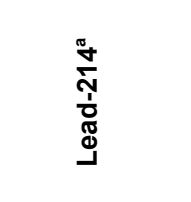 } & \multicolumn{2}{|c|}{ 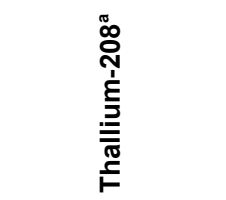 } & \multirow{3}{*}{ 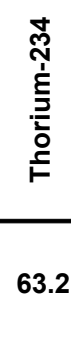 } \\
\hline \multirow{2}{*}{\multicolumn{3}{|c|}{ Final Action Levels }} & 5 & 15 & \multirow{2}{*}{12.7} & 5 & 15 & 5 & 15 & & & 5 & 15 & 5 & 15 & 5 & 15 & \\
\hline & & & $<15$ & $>15$ & & $<15$ & $>15$ & $<15$ & $>15$ & & & $<15$ & $>15$ & $<15$ & $>15$ & $<15$ & $>15$ & \\
\hline \multirow{4}{*}{ B05 } & 552B006 & $0.0-0.5$ & $\begin{array}{l}1.81 \\
(G)\end{array}$ & NA & -- & -- & NA & $1.12(\mathrm{G}, \mathrm{J})$ & NA & -- & -- & $2.09(J)^{c}$ & NA & $\begin{array}{l}1.23 \\
(\mathrm{G}, \mathrm{J})\end{array}$ & NA & $\begin{array}{l}0.69 \\
(G)\end{array}$ & NA & -- \\
\hline & 552B018 & $0.0-1.0$ & $\begin{array}{l}1.98 \\
(G)\end{array}$ & NA & -- & -- & NA & $1.21(\mathrm{G}, \mathrm{J})$ & NA & -- & -- & NA & $2.5(J)^{c}$ & NA & $\begin{array}{c}1.3 \\
(G, J)\end{array}$ & NA & $\begin{array}{l}0.77 \\
(\mathrm{G})\end{array}$ & -- \\
\hline & 552B019 & $8.0-9.0$ & NA & $\begin{array}{c}2.09 \\
(G)\end{array}$ & -- & NA & -- & NA & $1.16(\mathrm{G}, \mathrm{J})$ & -- & -- & NA & $2.63(\mathrm{~J})^{\mathrm{c}}$ & NA & $\begin{array}{c}1.3 \\
(G, J)\end{array}$ & NA & $\begin{array}{c}0.94 \\
(G)\end{array}$ & -- \\
\hline & 552B026 & $6.0-7.0$ & NA & $\begin{array}{l}1.88 \\
(G)\end{array}$ & -- & NA & -- & NA & $1.33(\mathrm{G}, \mathrm{J})$ & -- & -- & NA & $2.32(\mathrm{~J})^{\mathrm{c}}$ & NA & $\begin{array}{l}1.41 \\
(G, J)\end{array}$ & NA & $\begin{array}{l}0.76 \\
(\mathrm{G})\end{array}$ & -- \\
\hline \multirow{2}{*}{ B06 } & 552B007 & $0.0-0.5$ & $\begin{array}{l}2.21 \\
(G)\end{array}$ & NA & -- & -- & NA & $1.12(\mathrm{G}, \mathrm{J})$ & NA & $\begin{array}{c}0.4 \\
(G, L T)\end{array}$ & -- & $2.28(\mathrm{~J})^{\mathrm{c}}$ & NA & $\begin{array}{l}1.22 \\
(G, J)\end{array}$ & NA & $\begin{array}{l}0.63 \\
(\mathrm{G})\end{array}$ & NA & -- \\
\hline & 552B027 & $4.5-5.0$ & NA & $\begin{array}{c}2.31 \\
(G)\end{array}$ & -- & NA & -- & NA & $1.16(\mathrm{G}, \mathrm{J})$ & -- & -- & NA & $2.68(J)^{c}$ & NA & $\begin{array}{c}1.4 \\
(G, J)\end{array}$ & NA & $0.7(\mathrm{G})$ & -- \\
\hline \multirow{2}{*}{ B07 } & 552B008 & $0.0-0.5$ & $\begin{array}{l}1.83 \\
(G)\end{array}$ & NA & -- & -- & NA & $1.1(\mathrm{G}, \mathrm{J})$ & NA & $\begin{array}{c}0.31 \\
(G, L T)\end{array}$ & -- & $2.29(\mathrm{~J})^{\mathrm{c}}$ & NA & $\begin{array}{l}1.17 \\
(G, J)\end{array}$ & NA & $0.7(\mathrm{G})$ & NA & -- \\
\hline & 552B034 & $2.0-3.0$ & NA & $\begin{array}{l}1.97 \\
(\mathrm{G})\end{array}$ & -- & NA & -- & NA & $1.25(\mathrm{G}, \mathrm{J})$ & -- & -- & NA & $2.47(\mathrm{~J})^{\mathrm{C}}$ & NA & $\begin{array}{l}1.31 \\
(\mathrm{G}, \mathrm{J})\end{array}$ & NA & $\begin{array}{l}0.67 \\
(\mathrm{G})\end{array}$ & -- \\
\hline B08 & 552B009 & $0.0-0.5$ & $\begin{array}{c}2.26 \\
(\mathrm{G})\end{array}$ & NA & -- & -- & NA & $1.19(\mathrm{G}, \mathrm{J})$ & NA & $1.78(\mathrm{G})$ & -- & $2.26(\mathrm{~J})^{\mathrm{c}}$ & NA & $\begin{array}{l}1.41 \\
(G, J)\end{array}$ & NA & $\begin{array}{l}0.79 \\
(G)\end{array}$ & NA & -- \\
\hline B09 & 552B010 & $0.0-0.5$ & $\begin{array}{l}1.79 \\
(\mathrm{G})\end{array}$ & NA & -- & -- & NA & $1.02(\mathrm{G}, \mathrm{J})$ & NA & $0.5(\mathrm{G})$ & -- & $2.24(\mathrm{~J})^{\mathrm{c}}$ & NA & $\begin{array}{l}1.46 \\
(G, J)\end{array}$ & NA & $\begin{array}{l}0.74 \\
(G)\end{array}$ & NA & -- \\
\hline B10 & 552B011 & $0.0-0.5$ & $\begin{array}{l}1.88 \\
(G)\end{array}$ & NA & -- & -- & NA & $1.16(\mathrm{G}, \mathrm{J})$ & NA & $6.02(\mathrm{G})$ & -- & $2.89(\mathrm{~J})^{\mathrm{c}}$ & NA & $\begin{array}{l}1.61 \\
(G, J)\end{array}$ & NA & $0.7(\mathrm{G})$ & NA & -- \\
\hline
\end{tabular}


Table A.2-7

Soil Sample Results for Gamma-Emitting Radionuclides Detected Above Minimum Detectable Concentrations at CAS 12-23-05

(Page 3 of 6 )

\begin{tabular}{|c|c|c|c|c|c|c|c|c|c|c|c|c|c|c|c|c|c|c|}
\hline \multirow[b]{2}{*}{$\begin{array}{c}\text { Sample } \\
\text { Location }\end{array}$} & \multirow[b]{2}{*}{$\begin{array}{l}\text { Sample } \\
\text { Number }\end{array}$} & \multirow{3}{*}{$\begin{array}{l}\text { Depth } \\
\text { (ft bgs) }\end{array}$} & \multicolumn{16}{|c|}{ Contaminants of Potential Concern (pCi/g) } \\
\hline & & & \multicolumn{2}{|c|}{ 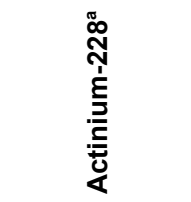 } & 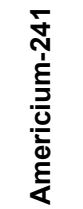 & \multicolumn{2}{|c|}{ 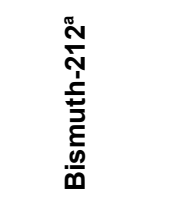 } & \multicolumn{2}{|c|}{ 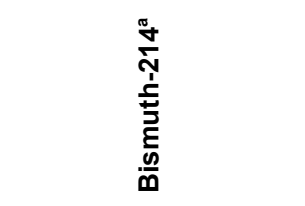 } & \multirow{3}{*}{ 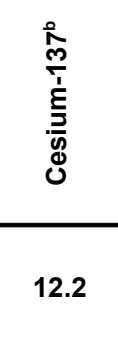 } & \multirow{3}{*}{$\begin{array}{l}\stackrel{8}{0} \\
\frac{1}{\pi} \\
\frac{0}{0} \\
0 \\
0\end{array}$} & \multicolumn{2}{|c|}{ 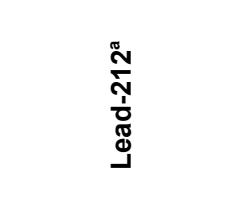 } & \multicolumn{2}{|c|}{ 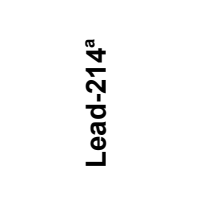 } & \multicolumn{2}{|c|}{ 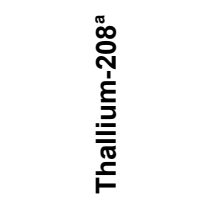 } & \multirow{3}{*}{ 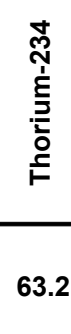 } \\
\hline \multicolumn{2}{|c|}{ Final Action Levels } & & 5 & 15 & \multirow{2}{*}{12.7} & 5 & 15 & 5 & 15 & & & 5 & 15 & 5 & 15 & 5 & 15 & \\
\hline \multicolumn{3}{|c|}{ Depth bgs (cm) } & $<15$ & $>15$ & & $<15$ & $>15$ & $<15$ & $>15$ & & & $<15$ & $>15$ & $<15$ & $>15$ & $<15$ & $>15$ & \\
\hline \multirow{2}{*}{ B11 } & 552B054 & $0.0-0.5$ & $\begin{array}{c}2.43 \\
(G)\end{array}$ & NA & -- & -- & NA & $1.39(\mathrm{G}, \mathrm{J})$ & NA & $1.27(\mathrm{G})$ & -- & $2.8(J)^{c}$ & NA & $\begin{array}{c}1.34 \\
(G, J)\end{array}$ & NA & $\begin{array}{l}0.93 \\
(G)\end{array}$ & NA & -- \\
\hline & 552B055 & $4.0-4.5$ & NA & $\begin{array}{l}1.9 \\
(G)\end{array}$ & -- & NA & -- & NA & $1.23(\mathrm{G}, \mathrm{J})$ & -- & -- & NA & $2.63(\mathrm{G})$ & NA & $\begin{array}{l}1.45 \\
(G, J)\end{array}$ & NA & $\begin{array}{l}0.79 \\
(G)\end{array}$ & -- \\
\hline \multirow{2}{*}{ B12 } & 552B056 & $0.0-0.5$ & $\begin{array}{l}1.73 \\
(\mathrm{G})\end{array}$ & NA & -- & -- & NA & $1.19(\mathrm{G}, \mathrm{J})$ & NA & -- & - & $2.2(\mathrm{~J})^{\mathrm{c}}$ & NA & $\begin{array}{c}1.36 \\
(\mathrm{G}, \mathrm{J})\end{array}$ & NA & $\begin{array}{l}0.59 \\
(G)\end{array}$ & NA & -- \\
\hline & 552B057 & $4.0-4.5$ & NA & $\begin{array}{l}1.9 \\
(\mathrm{G})\end{array}$ & -- & NA & -- & NA & $1.11(\mathrm{G}, \mathrm{J})$ & -- & -- & NA & $2.3(\mathrm{~J})^{\mathrm{C}}$ & NA & $\begin{array}{l}1.23 \\
(G, J)\end{array}$ & NA & $\begin{array}{l}0.64 \\
(\mathrm{G})\end{array}$ & -- \\
\hline B13 & 552B058 & $0.0-0.5$ & $\begin{array}{l}1.77 \\
(\mathrm{G})\end{array}$ & NA & -- & -- & NA & $1.18(\mathrm{G}, \mathrm{J})$ & NA & -- & -- & $2.43(\mathrm{~J})^{\mathrm{C}}$ & NA & $\begin{array}{c}1.25 \\
(G, J)\end{array}$ & NA & $0.7(\mathrm{G})$ & NA & -- \\
\hline B14 & 552B059 & $0.0-0.5$ & $\begin{array}{l}1.79 \\
(G)\end{array}$ & NA & -- & -- & NA & $1.39(\mathrm{G}, \mathrm{J})$ & NA & $0.95(\mathrm{G})$ & -- & $2.56(\mathrm{~J})^{\mathrm{c}}$ & NA & $\begin{array}{c}1.43 \\
(G, J)\end{array}$ & NA & $\begin{array}{l}0.81 \\
(G)\end{array}$ & NA & -- \\
\hline B15 & 552B060 & $0.0-0.5$ & $\begin{array}{c}2.66 \\
(G)\end{array}$ & NA & -- & -- & NA & $1.1(\mathrm{G}, \mathrm{J})$ & NA & $0.7(G)$ & -- & $2.25(\mathrm{~J})^{\mathrm{c}}$ & NA & $\begin{array}{c}1.3(\mathrm{G}, \\
\mathrm{J})\end{array}$ & NA & $\begin{array}{l}0.71 \\
(G)\end{array}$ & NA & -- \\
\hline BB01 & 552B016 & $1.0-2.0$ & NA & $\begin{array}{c}2.19 \\
(G)\end{array}$ & -- & NA & -- & NA & $1.22(\mathrm{G}, \mathrm{J})$ & -- & -- & NA & $2.78(\mathrm{~J})^{\mathrm{c}}$ & NA & $\begin{array}{c}1.35 \\
(G, J)\end{array}$ & NA & $\begin{array}{c}0.74 \\
(G)\end{array}$ & -- \\
\hline BB02 & 552B032 & $0.0-0.5$ & $\begin{array}{c}2.63 \\
(G)\end{array}$ & NA & -- & -- & NA & $1.37(\mathrm{G}, \mathrm{J})$ & NA & $2.74(\mathrm{G})$ & -- & $2.76(\mathrm{~J})^{\mathrm{c}}$ & NA & $\begin{array}{c}1.2(\mathrm{G}, \\
\mathrm{J})\end{array}$ & NA & $\begin{array}{l}0.76 \\
(G)\end{array}$ & NA & -- \\
\hline BB02 & 552B033 & $2.0-3.0$ & NA & $\begin{array}{l}1.88 \\
(G)\end{array}$ & -- & NA & -- & NA & $1.6(\mathrm{G}, \mathrm{J})$ & -- & -- & NA & $3.01(\mathrm{~J})^{\mathrm{c}}$ & NA & $\begin{array}{c}1.3 \\
(G, J)\end{array}$ & NA & $\begin{array}{l}1.04 \\
(G)\end{array}$ & -- \\
\hline BR01 & 552B014 & $0.0-1.0$ & NA & $\begin{array}{c}2.28 \\
(G)\end{array}$ & -- & NA & -- & NA & $1.44(\mathrm{G}, \mathrm{J})$ & -- & -- & NA & $2.79(\mathrm{~J})^{\mathrm{C}}$ & NA & $\begin{array}{l}1.52 \\
(G, J)\end{array}$ & NA & $0.8(\mathrm{G})$ & -- \\
\hline BR02 & 552B028 & $0.0-0.5$ & $\begin{array}{l}1.89 \\
(G)\end{array}$ & NA & -- & -- & NA & $1.39(\mathrm{G}, \mathrm{J})$ & NA & -- & -- & $2.66(\mathrm{~J})^{\mathrm{C}}$ & NA & $\begin{array}{c}1.29 \\
(G, J)\end{array}$ & NA & $\begin{array}{l}0.86 \\
(\mathrm{G})\end{array}$ & NA & $\begin{array}{c}4.2 \\
(G, T I)\end{array}$ \\
\hline
\end{tabular}


Table A.2-7

Soil Sample Results for Gamma-Emitting Radionuclides Detected Above Minimum Detectable Concentrations at CAS 12-23-05

(Page 4 of 6)

\begin{tabular}{|c|c|c|c|c|c|c|c|c|c|c|c|c|c|c|c|c|c|c|}
\hline \multirow[b]{2}{*}{$\begin{array}{c}\text { Sample } \\
\text { Location }\end{array}$} & \multirow[b]{2}{*}{$\begin{array}{l}\text { Sample } \\
\text { Number }\end{array}$} & \multirow{3}{*}{$\begin{array}{c}\text { Depth } \\
\text { (ft bgs) }\end{array}$} & \multicolumn{16}{|c|}{ Contaminants of Potential Concern (pCi/g) } \\
\hline & & & \multicolumn{2}{|c|}{ 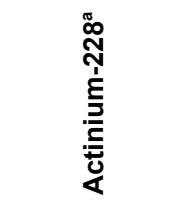 } & 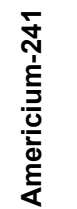 & \multicolumn{2}{|c|}{ 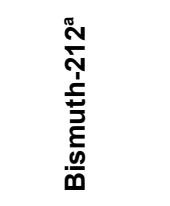 } & \multicolumn{2}{|c|}{ 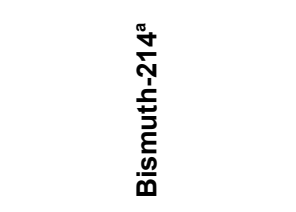 } & \multirow{3}{*}{ 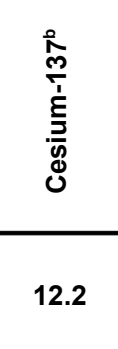 } & \multirow{3}{*}{$\begin{array}{l}\stackrel{8}{0} \\
\frac{1}{\pi} \\
\frac{0}{0} \\
0 \\
0\end{array}$} & \multicolumn{2}{|c|}{ 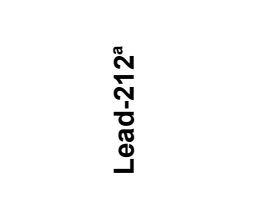 } & \multicolumn{2}{|c|}{ 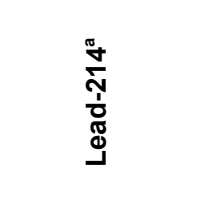 } & \multicolumn{2}{|c|}{ 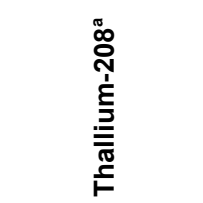 } & \multirow{3}{*}{ 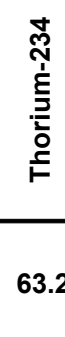 } \\
\hline \multicolumn{2}{|c|}{ Final Action Levels } & & 5 & 15 & \multirow{2}{*}{12.7} & 5 & 15 & 5 & 15 & & & 5 & 15 & 5 & 15 & 5 & 15 & \\
\hline \multicolumn{3}{|c|}{ Depth bgs (cm) } & $<15$ & $>15$ & & $<15$ & $>15$ & $<15$ & $>15$ & & & $<15$ & $>15$ & $<15$ & $>15$ & $<15$ & $>15$ & \\
\hline BR03 & 552B029 & $0.0-0.5$ & $\begin{array}{l}1.98 \\
(G)\end{array}$ & NA & -- & -- & NA & $1.18(\mathrm{G}, \mathrm{J})$ & NA & $0.73(\mathrm{G})$ & -- & $2.9(J)^{\mathrm{c}}$ & NA & $\begin{array}{c}1.41 \\
(G, J)\end{array}$ & NA & $\begin{array}{l}0.73 \\
(\mathrm{G})\end{array}$ & NA & -- \\
\hline BR04 & 552B030 & $0.0-0.5$ & $\begin{array}{c}2.58 \\
(G)\end{array}$ & NA & -- & -- & NA & $1.35(\mathrm{G}, \mathrm{J})$ & NA & $\begin{array}{c}0.46 \\
(G, L T)\end{array}$ & -- & $2.34(\mathrm{~J})^{\mathrm{c}}$ & NA & $\begin{array}{c}1.3(\mathrm{G}, \\
\mathrm{J})\end{array}$ & NA & $0.7(G)$ & NA & -- \\
\hline BR05 & 552B031 & $0.0-0.5$ & $\begin{array}{c}2.39 \\
(G)\end{array}$ & NA & -- & -- & NA & $0.82(\mathrm{G}, \mathrm{J})$ & NA & -- & -- & $2.56(\mathrm{~J})^{\mathrm{c}}$ & NA & $\begin{array}{c}1.2(\mathrm{G}, \\
\mathrm{J})\end{array}$ & NA & $\begin{array}{l}0.83 \\
(\mathrm{G})\end{array}$ & NA & -- \\
\hline \multirow{2}{*}{ BR06 } & 552B061 & $1.0-1.5$ & NA & $\begin{array}{c}3.24 \\
(G)\end{array}$ & -- & NA & -- & NA & $1.34(\mathrm{G}, \mathrm{J})$ & $38.6(G)$ & -- & NA & $4.05(J)^{c}$ & NA & $\begin{array}{l}1.47 \\
(G, J)\end{array}$ & NA & $\begin{array}{l}1.05 \\
(G)\end{array}$ & -- \\
\hline & 552B062 & $3.0-3.5$ & NA & $\begin{array}{c}2.16 \\
(G)\end{array}$ & -- & NA & $\begin{array}{l}2.6 \\
(G)\end{array}$ & NA & $0.94(\mathrm{G}, \mathrm{J})$ & -- & -- & NA & $2.34(\mathrm{~J})^{\mathrm{c}}$ & NA & $\begin{array}{c}1(\mathrm{G}, \\
\mathrm{J})\end{array}$ & NA & $\begin{array}{l}0.71 \\
(G)\end{array}$ & -- \\
\hline \multirow{4}{*}{ BR07 } & 552B051 & $0.5-1.0$ & NA & $\begin{array}{c}2.56 \\
(G)\end{array}$ & -- & NA & -- & NA & -- & $168(\mathrm{G})$ & $\begin{array}{l}0.69 \\
(G)\end{array}$ & NA & $2.47(J)^{c}$ & NA & -- & NA & $\begin{array}{l}0.73 \\
(G)\end{array}$ & -- \\
\hline & 552B052 & $2.5-3.0$ & NA & $\begin{array}{l}2.6 \\
(\mathrm{G})\end{array}$ & -- & NA & -- & NA & $1.07(\mathrm{G}, \mathrm{J})$ & $10.8(\mathrm{G})$ & -- & NA & $2.61(J)^{c}$ & NA & $\begin{array}{c}1.6 \\
(G, J)\end{array}$ & NA & $\begin{array}{l}0.84 \\
(\mathrm{G})\end{array}$ & -- \\
\hline & 552B066 & $1.0-1.5$ & NA & $\begin{array}{c}2.12 \\
(G)\end{array}$ & -- & NA & -- & NA & $1.4(\mathrm{G}, \mathrm{J})$ & $6.05(\mathrm{G})$ & -- & NA & $2.35(J)^{c}$ & NA & $\begin{array}{l}1.37 \\
(G, J)\end{array}$ & NA & $\begin{array}{c}0.99 \\
(\mathrm{G})\end{array}$ & -- \\
\hline & 552B067 & $3.0-3.5$ & NA & $\begin{array}{c}2.28 \\
(G)\end{array}$ & -- & NA & -- & NA & $1.07(\mathrm{G}, \mathrm{J})$ & -- & -- & NA & $2.64(J)^{c}$ & NA & $\begin{array}{l}1.25 \\
(G, J)\end{array}$ & NA & $\begin{array}{c}0.91 \\
(\mathrm{G})\end{array}$ & -- \\
\hline \multirow{3}{*}{ BR08 } & 552B043 & $0.0-1.0$ & NA & $\begin{array}{c}2.81 \\
(\mathrm{G})\end{array}$ & -- & NA & -- & NA & $1.17(\mathrm{G}, \mathrm{J})$ & $8.3(\mathrm{G})$ & -- & NA & $2.67(\mathrm{~J})^{\mathrm{c}}$ & NA & $\begin{array}{l}1.68 \\
(G, J)\end{array}$ & NA & $\begin{array}{c}0.79 \\
(\mathrm{G})\end{array}$ & -- \\
\hline & 552B044 & $1.0-2.0$ & NA & $\begin{array}{c}2.48 \\
(G)\end{array}$ & -- & NA & -- & NA & $1.32(\mathrm{G}, \mathrm{J})$ & $7.04(\mathrm{G})$ & -- & NA & $2.72(\mathrm{~J})^{\mathrm{c}}$ & NA & $\begin{array}{l}1.46 \\
(G, J)\end{array}$ & NA & $\begin{array}{c}0.89 \\
(\mathrm{G})\end{array}$ & -- \\
\hline & 552B045 & $1.0-2.0$ & NA & $\begin{array}{c}2.37 \\
(\mathrm{G})\end{array}$ & -- & NA & -- & NA & $1.59(\mathrm{G}, \mathrm{J})$ & $6.76(\mathrm{G})$ & -- & NA & $3.28(\mathrm{~J})^{\mathrm{c}}$ & NA & $\begin{array}{l}1.38 \\
(G, J)\end{array}$ & NA & $\begin{array}{c}0.99 \\
(G)\end{array}$ & -- \\
\hline
\end{tabular}


Table A.2-7

Soil Sample Results for Gamma-Emitting Radionuclides Detected Above Minimum Detectable Concentrations at CAS 12-23-05

(Page 5 of 6$)$

\begin{tabular}{|c|c|c|c|c|c|c|c|c|c|c|c|c|c|c|c|c|c|c|}
\hline \multirow[b]{2}{*}{$\begin{array}{l}\text { Sample } \\
\text { Location }\end{array}$} & \multirow[b]{2}{*}{$\begin{array}{l}\text { Sample } \\
\text { Number }\end{array}$} & \multirow{3}{*}{$\begin{array}{c}\text { Depth } \\
\text { (ft bgs) }\end{array}$} & \multicolumn{16}{|c|}{ Contaminants of Potential Concern (pCi/g) } \\
\hline & & & \multicolumn{2}{|c|}{ 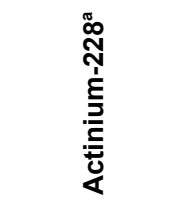 } & 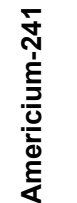 & \multicolumn{2}{|c|}{ 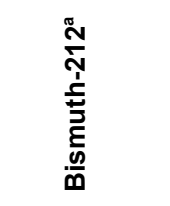 } & \multicolumn{2}{|c|}{ 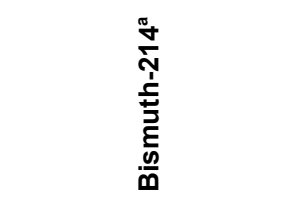 } & \multirow{3}{*}{ 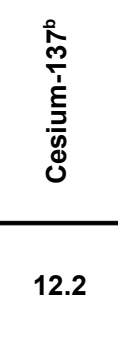 } & \multirow{3}{*}{$\begin{array}{l}\stackrel{8}{0} \\
\frac{1}{\pi} \\
\frac{0}{0} \\
0\end{array}$} & \multicolumn{2}{|c|}{ 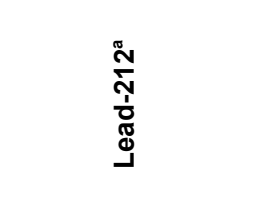 } & \multicolumn{2}{|c|}{ 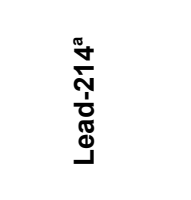 } & \multicolumn{2}{|c|}{ 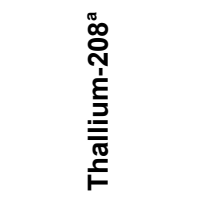 } & \multirow{3}{*}{ 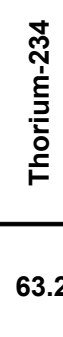 } \\
\hline \multicolumn{2}{|c|}{ Final Action Levels } & & 5 & 15 & \multirow{2}{*}{12.7} & 5 & 15 & 5 & 15 & & & 5 & 15 & 5 & 15 & 5 & 15 & \\
\hline \multicolumn{3}{|c|}{ Depth bgs (cm) } & $<15$ & $>15$ & & $<15$ & $>15$ & $<15$ & $>15$ & & & $<15$ & $>15$ & $<15$ & $>15$ & $<15$ & $>15$ & \\
\hline BR10 & 552B040 & $0.0-1.0$ & NA & $\begin{array}{c}1.82 \\
(G)\end{array}$ & -- & NA & -- & NA & $1.29(\mathrm{G}, \mathrm{J})$ & $7.1(\mathrm{G})$ & -- & NA & $2.8(J)^{c}$ & NA & $\begin{array}{l}1.48 \\
(G, J)\end{array}$ & NA & $\begin{array}{l}0.74 \\
(G)\end{array}$ & -- \\
\hline \multirow{2}{*}{ BR11 } & 552B035 & $1.0-2.0$ & NA & $\begin{array}{c}3.15 \\
(G)\end{array}$ & -- & NA & -- & NA & -- & $120(\mathrm{G})$ & -- & NA & $3.48(\mathrm{~J})^{\mathrm{c}}$ & NA & -- & NA & $\begin{array}{l}1.07 \\
(\mathrm{G})\end{array}$ & -- \\
\hline & 552B036 & $2.0-3.0$ & NA & $\begin{array}{c}2.44 \\
(G)\end{array}$ & -- & NA & -- & NA & $1.12(\mathrm{G}, \mathrm{J})$ & $\begin{array}{c}0.26 \\
(G, L T)\end{array}$ & -- & NA & $2.4(J)^{c}$ & NA & $\begin{array}{l}1.24 \\
(G, J)\end{array}$ & NA & $\begin{array}{l}0.71 \\
(G)\end{array}$ & -- \\
\hline BR12 & 552B050 & $0.0-0.5$ & $\begin{array}{c}2.18 \\
(G)\end{array}$ & NA & -- & -- & NA & $0.87(\mathrm{G}, \mathrm{J})$ & NA & $79(\mathrm{G})$ & $\begin{array}{c}0.345 \\
(\mathrm{G})\end{array}$ & $2.34(\mathrm{~J})^{\mathrm{c}}$ & NA & $\begin{array}{l}1.19 \\
(G, J)\end{array}$ & NA & $\begin{array}{l}0.54 \\
(G)\end{array}$ & NA & -- \\
\hline \multirow{3}{*}{ BR13 } & 552B063 & $0.5-2.0$ & NA & $\begin{array}{c}3.01 \\
(G)\end{array}$ & -- & NA & -- & NA & $1.78(\mathrm{G}, \mathrm{J})$ & $83.6(\mathrm{G})$ & -- & NA & $3.78(\mathrm{~J})^{\mathrm{c}}$ & NA & -- & NA & $\begin{array}{l}1.13 \\
(G)\end{array}$ & -- \\
\hline & 552B064 & $3.0-4.0$ & NA & $\begin{array}{r}2.17 \\
(G)\end{array}$ & -- & NA & $\begin{array}{l}3.7 \\
(G)\end{array}$ & NA & $0.98(\mathrm{G}, \mathrm{J})$ & $1.52(\mathrm{G})$ & -- & NA & $2.14(J)^{c}$ & NA & $\begin{array}{l}1.23 \\
(G, J)\end{array}$ & NA & $\begin{array}{l}0.81 \\
(G)\end{array}$ & -- \\
\hline & 552B065 & $3.0-4.0$ & NA & $\begin{array}{c}2.42 \\
(G)\end{array}$ & -- & NA & -- & NA & $0.98(\mathrm{G}, \mathrm{J})$ & $1.49(\mathrm{G})$ & -- & NA & $2.54(\mathrm{~J})^{\mathrm{c}}$ & NA & $\begin{array}{l}1.29 \\
(G, J)\end{array}$ & NA & $\begin{array}{l}0.74 \\
(G)\end{array}$ & -- \\
\hline BR14 & 552B047 & $0.5-1.0$ & NA & $\begin{array}{l}2.3 \\
(\mathrm{G})\end{array}$ & -- & NA & -- & NA & $1.49(\mathrm{G}, \mathrm{J})$ & $\begin{array}{c}0.47 \\
(G, L T)\end{array}$ & -- & NA & $2.51(J)^{c}$ & NA & $\begin{array}{l}1.26 \\
(G, J)\end{array}$ & NA & $\begin{array}{l}0.78 \\
(G)\end{array}$ & -- \\
\hline BR15 & 552B039 & $0.0-1.0$ & NA & $\begin{array}{c}2.03 \\
(G)\end{array}$ & -- & NA & -- & NA & $1.1(\mathrm{G}, \mathrm{J})$ & $2.52(\mathrm{G})$ & -- & NA & $2.41(J)^{c}$ & NA & $\begin{array}{l}1.17 \\
(G, J)\end{array}$ & NA & $\begin{array}{l}0.79 \\
(G)\end{array}$ & -- \\
\hline BR16 & 552B046 & $0.5-1.0$ & NA & $\begin{array}{c}2.09 \\
(G)\end{array}$ & -- & NA & -- & NA & $1.18(\mathrm{G}, \mathrm{J})$ & -- & -- & NA & $2.56(\mathrm{~J})^{\mathrm{c}}$ & NA & $\begin{array}{c}1.5 \\
(\mathrm{G}, \mathrm{J})\end{array}$ & NA & $\begin{array}{l}0.75 \\
(\mathrm{G})\end{array}$ & -- \\
\hline \multirow{2}{*}{ BR17 } & 552B037 & $1.5-2.0$ & NA & $\begin{array}{l}2.6 \\
(G) \\
\end{array}$ & -- & NA & -- & NA & -- & $\begin{array}{c}189 \\
(\mathrm{G}, \mathrm{M} 3)\end{array}$ & $\begin{array}{l}0.98 \\
(\mathrm{G}) \\
\end{array}$ & NA & $2.97(\mathrm{~J})^{\mathrm{c}}$ & NA & -- & NA & $\begin{array}{c}0.99 \\
(\mathrm{G})\end{array}$ & -- \\
\hline & 552B038 & $2.5-3.0$ & NA & $\begin{array}{c}2.18 \\
(G)\end{array}$ & -- & NA & -- & NA & $1.28(\mathrm{G}, \mathrm{J})$ & $1.03(\mathrm{G})$ & -- & NA & $2.32(\mathrm{~J})^{\mathrm{c}}$ & NA & $\begin{array}{l}1.21 \\
(G, J)\end{array}$ & NA & $\begin{array}{c}0.81 \\
(\mathrm{G})\end{array}$ & -- \\
\hline
\end{tabular}


Table A.2-7

\section{Soil Sample Results for Gamma-Emitting Radionuclides Detected Above Minimum Detectable Concentrations at CAS 12-23-05}

(Page 6 of 6$)$

\begin{tabular}{|c|c|c|c|c|c|c|c|c|c|c|c|c|c|c|c|c|c|c|}
\hline \multirow[b]{2}{*}{$\begin{array}{l}\text { Sample } \\
\text { Location }\end{array}$} & \multirow[b]{2}{*}{$\begin{array}{l}\text { Sample } \\
\text { Number }\end{array}$} & \multirow{3}{*}{$\begin{array}{c}\text { Depth } \\
\text { (ft bgs) }\end{array}$} & \multicolumn{16}{|c|}{ Contaminants of Potential Concern (pCi/g) } \\
\hline & & & \multicolumn{2}{|c|}{ 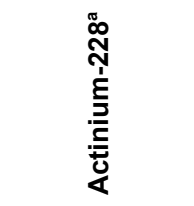 } & 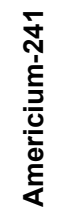 & \multicolumn{2}{|c|}{ 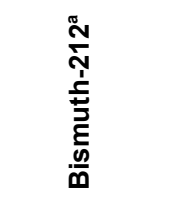 } & \multicolumn{2}{|c|}{ 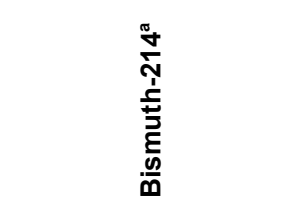 } & \multirow{3}{*}{ 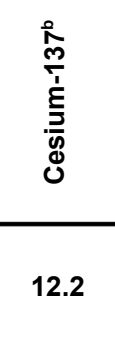 } & \multirow{3}{*}{$\begin{array}{l}\stackrel{8}{0} \\
\frac{1}{\pi} \\
\frac{1}{\pi} \\
0 \\
0\end{array}$} & \multicolumn{2}{|c|}{ 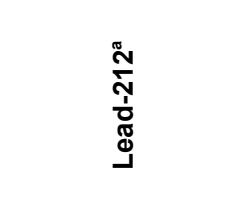 } & \multicolumn{2}{|c|}{ 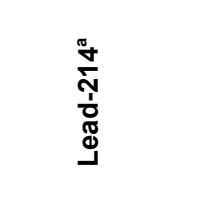 } & \multicolumn{2}{|c|}{ 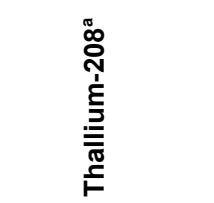 } & \multirow{3}{*}{ 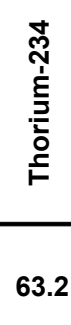 } \\
\hline \multicolumn{2}{|c|}{ Final Action Levels } & & 5 & 15 & \multirow{2}{*}{12.7} & 5 & 15 & 5 & 15 & & & 5 & 15 & 5 & 15 & 5 & 15 & \\
\hline \multicolumn{3}{|c|}{ Depth bgs (cm) } & $<15$ & $>15$ & & $<15$ & $>15$ & $<15$ & $>15$ & & & $<15$ & $>15$ & $<15$ & $>15$ & $<15$ & $>15$ & \\
\hline \multirow{2}{*}{ BR18 } & 552B041 & $0.0-1.0$ & NA & $\begin{array}{l}2.17 \\
(G)\end{array}$ & -- & NA & -- & NA & $1.44(\mathrm{G}, \mathrm{J})$ & $7.7(\mathrm{G})$ & -- & NA & $3.03(\mathrm{~J})^{\mathrm{c}}$ & NA & $\begin{array}{l}1.57 \\
(G, J)\end{array}$ & NA & $0.9(\mathrm{G})$ & -- \\
\hline & 552B042 & $2.0-2.5$ & NA & $\begin{array}{l}1.77 \\
(\mathrm{G})\end{array}$ & -- & NA & -- & NA & $1.06(\mathrm{G}, \mathrm{J})$ & $0.98(G)$ & -- & NA & $2.7(\mathrm{~J})^{\mathrm{c}}$ & NA & $\begin{array}{c}1.52 \\
(G, J)\end{array}$ & NA & $\begin{array}{l}0.77 \\
(\mathrm{G})\end{array}$ & -- \\
\hline B Battery 1 & 552B048 & $0.0-0.5$ & $\begin{array}{c}2.04 \\
(\mathrm{G})\end{array}$ & NA & $\begin{array}{l}1.17 \\
(J)^{\mathrm{c}}\end{array}$ & -- & NA & $1.53(\mathrm{G}, \mathrm{J})$ & NA & $2.16(\mathrm{G})$ & -- & $2.61(J)^{c}$ & NA & $\begin{array}{l}1.16 \\
(G, J)\end{array}$ & NA & $\begin{array}{c}0.73 \\
(G)\end{array}$ & NA & -- \\
\hline B Battery 2 & 552B049 & $0.0-0.5$ & $\begin{array}{c}2.33 \\
(\mathrm{G})\end{array}$ & NA & -- & -- & NA & $1.2(\mathrm{G}, \mathrm{J})$ & NA & $0.75(\mathrm{G})$ & -- & $2.35(J)^{c}$ & NA & $\begin{array}{c}1.5 \\
(G, J)\end{array}$ & NA & $\begin{array}{l}0.63 \\
(G)\end{array}$ & NA & -- \\
\hline
\end{tabular}

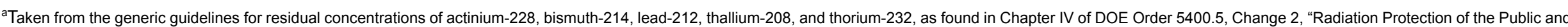

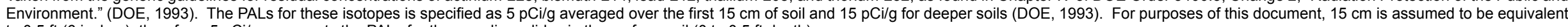
to $0.5 \mathrm{ft}$ ( 6 inches); therefore, $5 \mathrm{pCi} / \mathrm{g}$ represents the PALs for these radionuclides in the surface soil ( 0 to $0.5 \mathrm{ft}$ depth).

Recommended Screening Limits for Contaminated Surface Soil and Review Factors Relevant to Site-Specific Studies (NCRP,

${ }^{C} Q u a l i f i e r$ added to laboratory data; record accepted. Sample does not meet counting geometry requirements.

\section{$\mathrm{ft}$ bgs $=$ Feet below ground surface}

$\mathrm{cm}=$ Centimeter

$\mathrm{mrem} / \mathrm{yr}=$ Millirem per year

Ci/g $=$ Picocuries per gram

mum reporting limits

$<==$ Less than

$>=$ Greater than

Sample density differs by more than $15 \%$ of laboratory control sample density.

G

than requested minimum detectable concentration, greater than sample specific minimum detectable concentration.

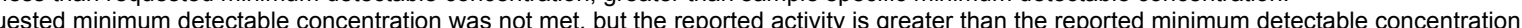

$\mathrm{NA}=$ Not applicable 
Table A.2-8

Soil Sample Results for Specific Isotopes Detected Above Minimum Detectable Concentrations at CAS 12-23-05 (Page 1 of 3 )

\begin{tabular}{|c|c|c|c|c|c|c|c|c|}
\hline \multirow[b]{2}{*}{$\begin{array}{l}\text { Sample } \\
\text { Location }\end{array}$} & \multirow[b]{2}{*}{$\begin{array}{l}\text { Sample } \\
\text { Number }\end{array}$} & \multirow[b]{2}{*}{$\begin{array}{c}\text { Depth } \\
\text { (ft bgs) }\end{array}$} & \multicolumn{6}{|c|}{ Contaminants of Potential Concern (pCi/g) } \\
\hline & & & 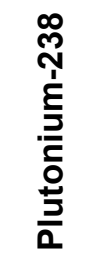 & 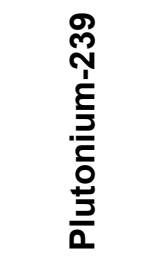 & 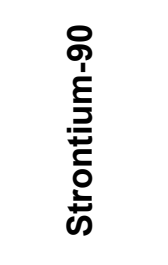 & 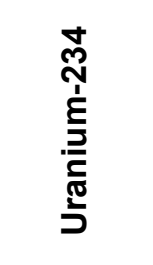 & 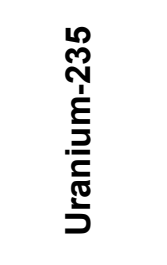 & 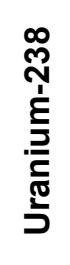 \\
\hline \multicolumn{3}{|c|}{ Final Action Levels ${ }^{a}$} & 13 & 12.7 & 838.3 & 143 & 17.6 & 105 \\
\hline \multirow{3}{*}{ B01 } & 552B001 & $0.0-0.5$ & 0.134 & 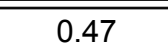 & $-0.054(J)^{b}$ & 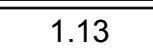 & 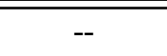 & 1.32 \\
\hline & 552B015 & $0.0-1.0$ & 0.73 & 2.74 & $\overline{--}$ & 1.42 & 0.078 & 1.44 \\
\hline & 552B025 & $5.0-6.0$ & 0.078 & 0.382 & $\overline{--}$ & 1.03 & 0.091 & 1.05 \\
\hline \multirow{4}{*}{ B02 } & 552B002 & $0.0-0.5$ & -- & -- & $-0.04(J)^{b}$ & $1.07(\mathrm{M} 3)$ & -- & 1.07 \\
\hline & 552B003 & $0.0-0.5$ & -- & -- & $-0.011(J)^{b}$ & 1.19 & 0.092 & 1.11 \\
\hline & 552B012 & $0.0-1.0$ & -- & $0.043(\mathrm{LT})$ & $\overline{--}$ & 1.16 & $\overline{--}$ & 1.06 \\
\hline & 552B013 & $5.0-6.0$ & -- & -- & -- & 1.04 & 0.049 (LT) & 0.99 \\
\hline \multirow{2}{*}{ B03 } & 552B004 & $0.0-0.5$ & 0.72 & 1.61 & $-0.039(\mathrm{~J})^{\mathrm{b}}$ & 1.28 & -- & 1.31 \\
\hline & 552B024 & $6.0-7.0$ & -- & -- & -- & 0.94 & 0.053 & 0.91 \\
\hline \multirow{2}{*}{ B04 } & 552B005 & $0.0-0.5$ & 0.068 & 0.57 & $0.16(\mathrm{~J})^{\mathrm{b}}$ & 1.12 & 0.061 & 1.1 \\
\hline & 552B017 & $0.0-1.0$ & 0.074 & 0.172 & -- & 1.18 & 0.05 & 1.07 \\
\hline \multirow{4}{*}{ B05 } & 552B006 & $0.0-0.5$ & 0.167 & 0.67 & $-0.058(J)^{b}$ & 1.22 & 0.062 & 1.04 \\
\hline & 552B018 & $0.0-1.0$ & -- & -- & -- & 1.04 & 0.064 & 1.1 \\
\hline & 552B019 & $8.0-9.0$ & -- & -- & -- & 1.06 & 0.061 & 1.06 \\
\hline & 552B026 & $6.0-7.0$ & $\overline{--}$ & $\overline{--}$ & $\overline{--}$ & 0.91 & -- & 0.95 \\
\hline \multirow{2}{*}{ B06 } & 552B007 & $0.0-0.5$ & 0.74 & 1.38 & $-0.02(J)^{b}$ & 1.26 & 0.056 & 1.29 \\
\hline & 552B027 & $4.5-5.0$ & $\overline{--}$ & $\overline{--}$ & $\overline{--}$ & 1.13 & 0.065 & 1.02 \\
\hline \multirow{2}{*}{ B07 } & 552B008 & $0.0-0.5$ & 0.215 & 0.39 & $0.036(J)^{b}$ & 1.06 & 0.061 & 1.13 \\
\hline & 552B034 & $2.0-3.0$ & $\overline{--}$ & $\overline{--}$ & $\overline{--}$ & 1.09 & 0.079 & 1.19 \\
\hline B08 & 552B009 & $0.0-0.5$ & 0.52 & 1.16 & $0.13(J)^{b}$ & 1.15 & -- & 1.15 \\
\hline B09 & 552B010 & $0.0-0.5$ & 0.084 & 0.236 & $0.055(J)^{b}$ & 1.08 & 0.066 & 1.16 \\
\hline B10 & 552B011 & $0.0-0.5$ & 0.68 & 1.59 & $1.52(\mathrm{~J})^{\mathrm{b}}$ & 1.02 & 0.053 & 1.13 \\
\hline \multirow{2}{*}{ B11 } & 552B054 & $0.0-0.5$ & $\overline{--}$ & 0.14 & $\overline{--}$ & 1.16 & 0.113 & 1.18 \\
\hline & 552B055 & $4.0-4.5$ & -- & -- & -- & 1.05 & 0.157 & 1.28 \\
\hline
\end{tabular}


Table A.2-8

Soil Sample Results for Specific Isotopes Detected Above Minimum Detectable Concentrations at CAS 12-23-05 (Page 2 of 3 )

\begin{tabular}{|c|c|c|c|c|c|c|c|c|}
\hline \multirow[b]{2}{*}{$\begin{array}{l}\text { Sample } \\
\text { Location }\end{array}$} & \multirow[b]{2}{*}{$\begin{array}{l}\text { Sample } \\
\text { Number }\end{array}$} & \multirow[b]{2}{*}{$\begin{array}{c}\text { Depth } \\
\text { (ft bgs) }\end{array}$} & \multicolumn{6}{|c|}{ Contaminants of Potential Concern (pCi/g) } \\
\hline & & & 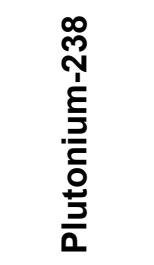 & 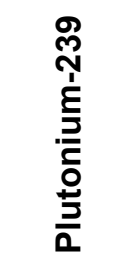 & 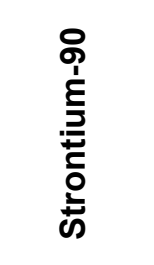 & 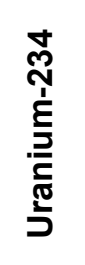 & 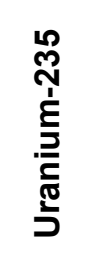 & 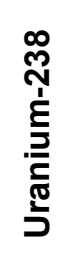 \\
\hline \multicolumn{3}{|c|}{ Final Action Levels ${ }^{a}$} & 13 & 12.7 & 838.3 & 143 & 17.6 & 105 \\
\hline \multirow{2}{*}{ B12 } & 552B056 & $0.0-0.5$ & -- & -- & -- & 1.04 & 0.073 & 0.98 \\
\hline & 552B057 & $4.0-4.5$ & -- & -- & -- & 1.06 & 0.092 & 0.99 \\
\hline B13 & 552B058 & $0.0-0.5$ & -- & 0.136 & -- & 1.35 & 0.08 & 1.33 \\
\hline B14 & 552B059 & $0.0-0.5$ & 0.55 & 1.36 & -- & 1.01 & 0.099 & 1.07 \\
\hline B15 & 552B060 & $0.0-0.5$ & 0.129 & 0.43 & -- & 1.13 & 0.109 & 1.1 \\
\hline BB01 & 552B016 & $1.0-2.0$ & -- & -- & -- & 1.16 & 0.059 & 1.12 \\
\hline \multirow{2}{*}{ BB02 } & 552В032 & $0.0-0.5$ & -- & 0.171 & -- & 1.29 & -- & 1.32 \\
\hline & 552В033 & $2.0-3.0$ & -- & -- & -- & 1.21 & 0.055 & 1.27 \\
\hline BR01 & 552B014 & $0.0-1.0$ & 0.149 & 0.5 & -- & 1.17 & 0.073 & 1.08 \\
\hline BR02 & 552B028 & $0.0-0.5$ & -- & -- & -- & 1.08 & -- & 1.17 \\
\hline BR03 & 552B029 & $0.0-0.5$ & -- & -- & -- & 1.02 & 0.063 & 1.04 \\
\hline BR04 & 552B030 & $0.0-0.5$ & -- & -- & -- & 1.04 & -- & 1.09 \\
\hline BR05 & 552B031 & $0.0-0.5$ & -- & -- & -- & 1.09 & 0.078 & 1.07 \\
\hline \multirow{2}{*}{ BR06 } & 552B061 & $1.0-1.5$ & 0.114 & 0.45 & 3.81 & 3.33 & 0.106 & 1.84 \\
\hline & 552B062 & $3.0-3.5$ & -- & -- & -- & 1.09 & 0.066 & 1.05 \\
\hline \multirow{4}{*}{ BR07 } & 552B051 & $0.5-1.0$ & $1.12(\mathrm{~J})^{\mathrm{C}}$ & $3.38(\mathrm{~J})^{\mathrm{c}}$ & 16.3 & 1.76 & 0.151 & 1.42 \\
\hline & 552B052 & $2.5-3.0$ & -- & -- & -- & 1.41 & 0.071 & 1.27 \\
\hline & 552B066 & $1.0-1.5$ & 0.052 & 1.81 & $0.41(\mathrm{LT})$ & 1.68 & 0.069 & 1.28 \\
\hline & 552B067 & $3.0-3.5$ & - & -- & $\overline{--}$ & 1.07 & -- & 1.11 \\
\hline \multirow{3}{*}{ BR08 } & $552 \mathrm{~B} 043$ & $0.0-1.0$ & 0.099 & 0.47 & $0.46(\mathrm{LT})$ & 1.22 & - & 1.32 \\
\hline & 552B044 & $1.0-2.0$ & - & 0.118 & -- & 1.19 & -- & 1.19 \\
\hline & $552 \mathrm{~B} 045$ & $1.0-2.0$ & 0.14 & 0.66 & $\overline{--}$ & 1.16 & - & 1.22 \\
\hline BR10 & 552B040 & $0.0-1.0$ & $0.16(\mathrm{M} 3)$ & 1.26 & $0.33(\mathrm{LT})$ & 1.01 & -- & 1.04 \\
\hline
\end{tabular}




\section{Table A.2-8 \\ Soil Sample Results for Specific Isotopes Detected Above Minimum Detectable Concentrations at CAS 12-23-05}

(Page 3 of 3 )

\begin{tabular}{|c|c|c|c|c|c|c|c|c|}
\hline \multirow[b]{2}{*}{$\begin{array}{l}\text { Sample } \\
\text { Location }\end{array}$} & \multirow[b]{2}{*}{$\begin{array}{l}\text { Sample } \\
\text { Number }\end{array}$} & \multirow[b]{2}{*}{$\begin{array}{c}\text { Depth } \\
\text { (ft bgs) }\end{array}$} & \multicolumn{6}{|c|}{ Contaminants of Potential Concern (pCi/g) } \\
\hline & & & 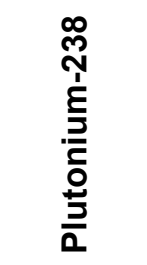 & 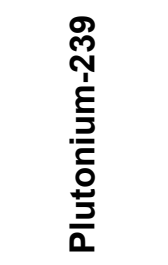 & 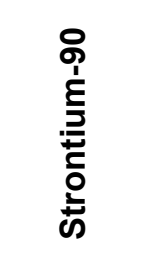 & 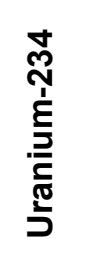 & 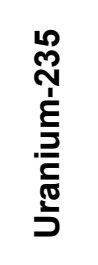 & 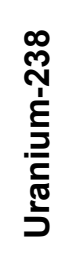 \\
\hline \multicolumn{3}{|c|}{ Final Action Levels ${ }^{a}$} & 13 & 12.7 & 838.3 & 143 & 17.6 & 105 \\
\hline \multirow{2}{*}{ BR11 } & 552B035 & $1.0-2.0$ & 0.59 & 1.91 & 8.9 & 2.37 & 0.107 & 1.64 \\
\hline & 552B036 & $2.0-3.0$ & $\overline{--}$ & $\overline{--}$ & $\overline{--}$ & 1.2 & -- & 1.02 \\
\hline BR12 & 552B050 & $0.0-0.5$ & $0.85(J)^{c}$ & $2.81(\mathrm{~J})^{\mathrm{c}}$ & 5 & 1.02 & 0.103 & 1.11 \\
\hline \multirow{3}{*}{ BR13 } & 552B063 & $0.5-2.0$ & 0.315 & 0.87 & 5.9 & 2.55 & 0.097 & 1.64 \\
\hline & 552B064 & $3.0-4.0$ & -- & 0.084 & -- & 1.19 & 0.06 & 0.95 \\
\hline & 552B065 & $3.0-4.0$ & -- & 0.191 & -- & 1.2 & -- & 1.14 \\
\hline BR14 & 552B047 & $0.5-1.0$ & -- & -- & -- & 1.12 & -- & 1.05 \\
\hline BR15 & 552B039 & $0.0-1.0$ & 0.053 & 0.257 & -- & 1.07 & -- & 1.17 \\
\hline BR16 & 552B046 & $0.5-1.0$ & -- & -- & -- & 1 & 0.099 & 0.95 \\
\hline \multirow{2}{*}{ BR17 } & 552B037 & $1.5-2.0$ & 1.5 & 4.36 & 19 & 1.6 & 0.099 & 1.56 \\
\hline & 552B038 & $2.5-3.0$ & -- & $0.034(\mathrm{LT})$ & -- & 1.29 & -- & 1.12 \\
\hline \multirow{2}{*}{ BR18 } & 552B041 & $0.0-1.0$ & 0.089 & 0.48 & $0.27(\mathrm{LT})$ & 1.05 & 0.092 & 1.14 \\
\hline & 552B042 & $2.0-2.5$ & 0.265 & 0.65 & -- & 1.02 & -- & 1.11 \\
\hline B Battery 1 & 552B048 & $0.0-0.5$ & $0.88(J)^{c}$ & $2.63(\mathrm{~J})^{\mathrm{c}}$ & -- & 1 & -- & 1.06 \\
\hline B Battery 2 & 552B049 & $0.0-0.5$ & $0.199(\mathrm{~J})^{\mathrm{c}}$ & $0.86(\mathrm{~J})^{\mathrm{c}}$ & -- & 0.97 & 0.095 & 1.13 \\
\hline
\end{tabular}

${ }^{a}$ Taken from the construction, commercial, industrial land use scenario in Table 2.1 of the NCRP Report No. 129 Recommended Screening Limits for Contaminated Surface Soil and Review Factors Relevant to Site-Specific Studies (NCRP, 1999). The values provided in this source document is based on a 25-mrem/yr dose.

${ }^{b}$ Qualifier added to laboratory data; record accepted. Laboratory control sample recovery exceeds control limits.

${ }^{\circ}$ Qualifier added to laboratory data; record accepted. Duplicate precision analysis (relative percent difference) exceeds control limits.

$\mathrm{ft}$ bgs $=$ Feet below ground surface

$\mathrm{mrem} / \mathrm{yr}=$ Millirem per year

$\mathrm{pCi} / \mathrm{g}=$ Picocuries per gram

$\mathrm{J}=$ Estimated value.

$\mathrm{LT}=$ Result is less than requested minimum detectable concentration, greater than sample specific minimum detectable concentration .

M3 = The requested minimum detectable concentration was not met, but the reported activity is greater than the reported minimum

detectable concentration.

-- = Not detected above minimum reporting limits. 


\section{A.3.0 Waste Management}

Investigation-derived waste was generated during the field investigation activities at CAS 12-23-05. The waste streams generated include decontamination rinse water, disposable personal protective equipment (PPE), disposable sampling equipment, debris, and miscellaneous waste removed as best management practice during the investigation activities. Investigation-derived waste was segregated to the greatest extent possible, and waste minimization techniques were integrated into the field activities to reduce the amount of waste generated. Controls were in place to minimize the use of hazardous materials and the unnecessary generation of hazardous and/or mixed waste.

Decontamination activities were planned and executed to minimize the volume of rinsate generated.

The amount, type, and source of waste placed into each drum was recorded in WM logbooks. Waste generated during the investigation that was known to be hazardous based on process knowledge and/or sample analytical results was placed in containers and labeled as "Hazardous Waste." Potentially hazardous waste generated during the investigation was placed in containers and labeled as "Hazardous Waste - Pending Analysis." One Hazardous Waste Accumulation Area was established to manage hazardous and potentially hazardous waste generated during the CAI.

\section{A.3.1 Characterization}

Analytical results for each drum of waste or associated samples were reviewed to ensure compliance with federal regulations, state regulations, DOE directives/policies, guidance, and waste disposal criteria.

\section{A.3.2 Waste Streams}

Investigation-derived waste generated during the investigation was segregated into the following waste streams:

- PPE and disposable sampling equipment.

- Decontamination rinsate. 
- Debris including, but not limited to, plastic sheeting, glass/plastic sample jars, PPE, soil, sampling scoops, aluminum foil, and bowls.

- Contaminated soil and associated debris (e.g., battery)

\section{A.3.3 Investigation-Derived Waste Generated}

A total of three drums of IDW were generated during the investigation:

- Two drums of rinsate were declared as sanitary waste (non-hazardous) and recommended for disposal at the Area 23 sewage lagoon.

- One drum contains battery parts (containing lead) and was therefore declared hazardous and disposed of in accordance with the requirements contained in the NTS Waste Acceptance Criteria (NNSA/NV, 2003).

Office waste and lunch trash was disposed of throughout the project as sanitary waste and disposed of in the Area 23 Mercury landfill. Sanitary industrial waste was inspected and disposed of in the Area 9 U10c industrial waste landfill.

\section{A.3.4 Waste Characterization Samples}

Waste characterization samples were collected from drummed waste, as necessary, to facilitate full characterization of the waste for disposal. Although, results of waste characterization samples are not presented in this document, complete results for all samples are maintained in project files. Analytical results indicated the samples did not exceed the RCRA toxicity characteristic leaching procedure limit for any metal. 


\section{A.4.0 Quality Assurance}

This section contains a summary of QA/QC measures implemented during the sampling and analysis activities conducted in support of the CAU 552 CAI. The following sections discuss the data validation process, QC samples, and nonconformances. A detailed evaluation of the DQIs is presented in Appendix B.

Laboratory analyses were conducted for samples used in the decision-making process to provide a quantitative measurement of any COPCs present. Rigorous QA/QC was implemented for all laboratory samples including documentation, verification and validation of analytical results, and affirmation of DQI requirements related to laboratory analysis. Detailed information regarding the QA program is contained in the Industrial Sites QAPP (NNSA/NV, 2002).

\section{A.4.1 Data Validation}

Data validation was performed in accordance with the Industrial Sites QAPP (NNSA/NV, 2002) and approved protocols and procedures. All laboratory data from samples collected and analyzed for CAU 552 were evaluated for data quality according to the EPA Functional Guidelines (EPA, 1994a and 1999). These guidelines are implemented in a tiered process and are presented in Section A.4.1.1, Section A.4.1.2, and Section A.4.1.3. Data were reviewed to ensure that samples were appropriately processed and analyzed, and the results were evaluated using validation criteria. Documentation of the data qualifications resulting from these reviews is retained in project files as a hard copy and electronic media.

One hundred percent of the data analyzed as part of this investigation were subjected to Tier I and Tier II evaluations. A Tier III evaluation was performed on approximately 5 percent of the data analyzed.

\section{A.4.1.1 Tier I Evaluation}

Tier I evaluation for chemical and radiochemical analysis examines, but is not limited to:

- Sample count/type consistent with chain of custody

- Analysis count/type consistent with chain of custody 
- Correct sample matrix

- Significant problems stated in cover letter or case narrative

- Completeness of certificates of analysis

- Completeness of Contract Laboratory Program (CLP) or CLP-like packages

- Completeness of signatures, dates, and times on chain of custody

- Condition-upon-receipt variance form included

- Requested analyses performed on all samples

- Date received/analyzed given for each sample

- Correct concentration units indicated

- Electronic data transfer supplied

- Results reported for field and laboratory QC samples

- Whether or not the deliverable met the overall objectives of the project

\section{A.4.1.2 Tier II Evaluation}

Tier II evaluation for chemical and radiochemical analysis examines, but is not limited to:

\section{Chemical:}

- Correct detection limits achieved.

- Sample date, preparation date, and analysis date for each sample.

- Holding time criteria met.

- Quality control batch association for each sample.

- Cooler temperature upon receipt.

- Sample $\mathrm{pH}$ for aqueous samples, as required.

- Detection limits properly adjusted for dilution, as required.

- Blank contamination evaluated and applied to sample results/qualifiers.

- Matrix spike (MS)/matrix spike duplicate (MSD) percent recoveries (\%R) and relative percent differences (RPDs) evaluated and qualifiers applied to laboratory results, as necessary.

- Field duplicate RPDs evaluated using professional judgment and qualifiers applied to. laboratory results, as necessary

- Laboratory duplicate RPDs evaluated and qualifiers applied to laboratory results, as necessary.

- Surrogate \%R evaluated and qualifiers applied to laboratory results, as necessary.

- Laboratory control sample (LCS) \%R evaluated and qualifiers applied to laboratory results, as necessary. 
- Initial and continuing calibration evaluated and qualifiers applied to laboratory results, as necessary.

- Internal standard evaluation.

- Mass spectrometer tuning criteria.

- Organic compound quantitation.

- Inductively coupled plasma interference check sample evaluation.

- Graphite furnace atomic absorption QC.

- Inductively coupled plasma serial dilution effects.

- Recalculation of 10 percent of laboratory results from raw data.

\section{Radioanalytical:}

- Correct detection limits achieved.

- Blank contamination evaluated and, if significant, qualifiers are applied to sample results.

- Certificate of Analysis consistent with data package documentation.

- Quality control sample results (duplicates, laboratory control samples, laboratory blanks) evaluated and used to determine laboratory result qualifiers.

- Sample results, uncertainty, and minimum detectable concentration evaluated.

- Detector system calibrated with National Institute for Standards and Technology (NIST)traceable sources.

- Calibration sources preparation was documented, demonstrating proper preparation and appropriateness for sample matrix, emission energies, and concentrations.

- Detector system response to daily or weekly background and calibration checks for peak energy, peak centroid, peak full-width half-maximum, and peak efficiency, depending on the detection system.

- Tracers NIST-traceable, appropriate for the analysis performed, and recoveries that met QC requirements.

- Documentation of all QC sample preparation complete and properly performed.

- Spectra lines, photon emissions, particle energies, peak areas, and background peak areas support the identified radionuclide and its concentration. 


\section{A.4.1.3 Tier III}

The Tier III review is an independent examination of the Tier II evaluation. The Tier III review duplicates the Tier II review for a limited number of samples (typically 5 percent) by an independent agency and includes the following additional evaluations:

\section{Chemical:}

- Recalculation of all laboratory results from raw data.

\section{Radioanalytical:}

- QC sample results (e.g., calibration source concentration, \%R, and RPD) verified.

- Radionuclides and their concentration validated as appropriate considering their decay schemes, half-lives, and process knowledge and history of the facility and site.

- Each identified line in spectra verified against emission libraries and calibration results.

- Independent identification of spectra lines, area under the peaks, and quantification of radionuclide concentration in a random number of sample results.

A Tier III review of 5 percent of the sample analytical data was performed by TechLaw, Inc., of Lakewood, Colorado. Tier II and Tier III results were compared and where differences were noted, data were reviewed and changes made accordingly.

\section{A.4.2 Quality Control Samples}

Field QC samples consisted of 10 trip blanks, 2 field blanks, 1 equipment rinsate blank, 4 MS/MSDs, and 4 FDs collected and submitted for the appropriate analysis by the laboratory analytical methods shown in Table A.2-2. The QC samples were assigned individual sample numbers and sent to the laboratory "blind." Additional samples were selected by the laboratory to be analyzed as laboratory duplicates.

\section{A.4.2.1 Field Quality Control Samples}

Review of the field blank analytical data for soil sampling indicates that there was no cross-contamination due to transportation practices or the ambient conditions and that decontamination was adequate. Field and equipment rinsate blanks were analyzed for the applicable parameters listed in Table A.2-2 and trip blanks were analyzed for VOCs only. 
During the sampling events, 4 field duplicates were sent as blind samples to the laboratory to be analyzed for the investigation parameters listed in Table A.2-2. The DQI of precision was calculated from the duplicate results (i.e., RPDs between the field duplicate sample results) and evaluated using the guidance set forth in the EPA Functional Guidelines (EPA, 1994a).

\section{A.4.2.2 Laboratory Quality Control Samples}

Analysis of method QC blanks were performed on each sample delivery group (SDG) for inorganics. Analysis for surrogate spikes and preparation blanks (PBs) were performed on each SDG for organics only. Initial and continuing calibration and LCSs were performed for each SDG by EMAX Laboratories, Inc. The results of these analyses were used to qualify associated environmental sample results according to the EPA Functional Guidelines (EPA, 1999). Documentation of data qualifications resulting from the application of these guidelines is retained in project files as both hard copy and electronic media.

The laboratory included a PB, LCS, and a laboratory duplicate sample with each batch of field samples analyzed for radionuclides.

\section{A.4.3 Field Nonconformances}

There were no field nonconformances identified for the CAI.

\section{A.4.4 Laboratory Nonconformances}

Laboratory nonconformances are generally due to inconsistencies in the analytical instrumentation operation, sample preparations, extractions, missed holding times, and fluctuations in internal standard and calibration results. Five nonconformances were issued by the laboratory that may or may not have resulted in qualifying data. These laboratory nonconformances have been accounted for during the data qualification process. 


\section{A.5.0 References}

BN, see Bechtel Nevada.

Bechtel Nevada. 1995. Nevada Test Site Performance Objective for Certification of Nonradioactive Hazardous Waste, Rev. 0, G-E11/96.01. Las Vegas, NV.

CFR, see Code of Federal Regulations.

Code of Federal Regulations. 2002. Title 40 CFR, "Protection of Environment," Parts 260-282,

"Hazardous Waste Management." Washington, DC: U.S. Government Printing Office.

DOE, see U.S. Department of Energy.

DOE/NV, see U.S. Department of Energy, Nevada Operations Office.

EPA, see U.S. Environmental Protection Agency.

FFACO, see Federal Facility Agreement and Consent Order.

Federal Facility Agreement and Consent Order. 1996 (as amended). Agreed to by the State of Nevada, the U.S. Department of Energy, and the U.S. Department of Defense.

Moore, J., Science Applications International Corporation. 1999. Memorandum to M. Todd (Science Applications International Corp.), "Background Concentrations for NTS and TTR Soil Samples," 3 February. Las Vegas, NV.

NAC, see Nevada Administrative Code.

NBMG, see Nevada Bureau of Mines and Geology.

NCRP, see National Council on Radiation Protection and Measurements.

NNSA/NV, see U.S. Department of Energy, National Nuclear Security Administration Nevada Operations Office.

NNSA/NSO, see U.S. Department of Energy, National Nuclear Security Administration Nevada Site Office.

National Council on Radiation Protection and Measurements. 1999. Recommended Screening Limits for Contaminated Surface Soil and Review of Factors Relevant to Site-Specific Studies/National Council on Radiation Protection and Measurements, NCRP Report No. 129. Bethesda, MD. 
Nevada Administrative Code. 2003. NAC 445A, "Water Controls.” Carson City, NV.

Nevada Bureau of Mines and Geology. 1998. Mineral and Energy Resource Assessment of the Nellis Air Force Range, Open-File Report 98-1. Reno, NV.

SNJV, see Stoller-Navarro Joint Venture

Stoller-Navarro Joint Venture. 2004. Industrial Sites Health and Safety Plan, Rev. 0. Las Vegas, NV.

Stoller-Navarro Joint Venture. 2005. Field Investigation Documentation in Project Files, Las Vegas, NV.

U.S. Department of Energy. 1993. DOE Order 5400.5 Change 2, "Radiation Protection of the Public and the Environment." Washington, DC.

U.S. Department of Energy, Nevada Operations Office. 2000. NV/YMP Radiological Control Manual, Rev. 4, DOE/NV/11718-079. Prepared by Bechtel Nevada. Las Vegas, NV.

U.S. Department of Energy, National Nuclear Security Administration Nevada Operations Office. 2002. Industrial Sites Quality Assurance Project Plan, Nevada Test Site, Nevada, Rev. 3, DOE/NV--372. Las Vegas, NV.

U.S. Department of Energy, National Nuclear Security Administration Nevada Site Office. 2005. Corrective Action Investigation Plan for Corrective Action Unit 552: Area 12 Muckpile and Ponds, Nevada Test Site, Nevada, Rev.1 DOE/NV--962. Las Vegas, NV.

U.S. Environmental Protection Agency. 1994. Guidance for the Data Quality Objectives Process, EPA QA/G-4. Washington, DC.

U.S. Environmental Protection Agency. 1996. Test Methods for Evaluating Solid Waste, Physical/Chemical Methods, SW-846, 3rd Edition, CD-ROM PB97-501928GEI. Washington, DC.

U.S. Environmental Protection Agency. 1999. Contract Laboratory Program National Functional Guidelines for Organic Data Review, EPA 540/R-99/008. Washington, DC.

U.S. Environmental Protection Agency. 2002. Region 9 Preliminary Remediation Goals (PRGs). As accessed on July 1, 2004 at http://www.epa.gov/region09/waste/sfund/prg/index.htm. 


\section{Appendix B}

\section{Data Assessment for CAU 552}




\section{B.1.0 Data Assessment}

The Data Quality Assessment (DQA) process is the scientific evaluation of the actual investigation results to determine whether the Data Quality Objectives (DQO) criteria established in the CAU 552 CAIP were met and whether DQO decisions can be resolved at the desired level of confidence. The DQO Process ensures that the right type, quality, and quantity of data will be available to support the resolution of those decisions at an appropriate level of confidence. Using both the DQO and DQA processes help to ensure that DQO decisions are sound and defensible.

As required by Section 5.5 of the Industrial Sites QAPP (NNSA/NV, 2002), a DQA was performed to verify DQO assumptions and document performance of the DQO tests listed in Appendix A of the CAU 522 CAIP. This assessment was performed following the EPA Guidelines for Data Quality Assessments: Practical Methods for Data Analysis (EPA, 1998) document referenced in Section 5.5 of the Industrial Sites QAPP (NNSA/NV, 2002).

The DQA involves five steps that begin with a review of the DQOs and end with an answer to the DQO decisions. The five steps are briefly summarized as follows:

Step 1: Review DQOs and Sampling Design - Review the DQO Process to provide context for analyzing the data. State the primary statistical hypotheses; confirm the limits on decision errors for committing false rejection (Type I) or false acceptance (Type II) decision errors; and review any special features, potential problems, or any deviations to the sampling design.

Step 2: Conduct a Preliminary Data Review - A preliminary data review should be performed by reviewing QA reports and inspecting the data both numerically and graphically, validating and verifying the data to ensure that the measurement systems performed in accordance with the criteria specified, and using the validated dataset to determine whether the quality of the data is satisfactory.

Step 3: Select the Test - Select the test based on the population of interest, population parameter, and the hypotheses. Identify the key underlying assumptions that could cause a change in one of the DQO decisions. 
Step 4: Verify the Assumptions - Perform tests of assumptions. If data are missing or are censored, determine the impact on DQO decision error.

Step 5: Draw Conclusions from the Data - Perform the calculations required for the test.

\section{B.1.1 Review DQOs and Sampling Design}

This section contains a review of the DQO process presented in Appendix A of the CAU 552 CAIP. The DQO decisions are presented with the DQO provisions to limit false rejection (false negative) or false acceptance (false positive) decision errors. Special features, potential problems, or any deviations to the sampling design are also presented.

Two DQO decisions are presented in the CAU 552 CAIP:

- Decision I - "Is a COC present in environmental media within the CAS at a concentration that could pose an unacceptable risk to human health and the environment?"

- Decision II - "If a COC is present, is sufficient information available to evaluate appropriate corrective action alternatives?"

\section{B.1.1.1 Decision I Decision Rules}

\section{Decision Rules:}

Null Hypothesis: A COC is present.

Alternative condition: A COC is not present.

Population Parameter: The maximum observed sample result:

- If the population parameter of any COPC in a target population exceeds the PAL for that COPC, then that COPC is identified as a COC, and Decision II samples will be collected and the extent determined.

- If COPC concentrations are less than the corresponding PAL, then the decision will be no further action. 


\section{B.1.1.1 DQO Provisions to Limit False Negative Decision Error}

A false negative decision error (where consequences are more severe) was controlled by meeting the following criteria:

1. Having a high degree of confidence that locations selected will identify COCs if present anywhere within the CAS, and

2. Having a high degree of confidence that analyses conducted will be sufficient to detect any COCs present in the samples.

3. Having a high degree of confidence that the dataset is of sufficient quality and completeness.

\section{Criteria 1:}

The following criteria [stipulated in the CAU 552 DQOs (NNSA/NSO, 2005)] were used in selecting sample locations.

1. Selection of sampling locations associated with field-screening results was accomplished by analyzing samples for VOCs using a photoionization detector and for alpha and beta/gamma emitting radionuclides using a hand-held radiological survey instrument.

2. Selection of sampling locations within the confines of the pond berms, along the berm walls, and areas just outside the berms.

3. Random sample locations within the ponds were generated using Visual Sample Plan computer program.

4. Selection of sampling locations associated with general storm drainage adjacent to but outside of the ponds that lead eastward from the CAS.

5. Selection of sampling locations associated with surface and subsurface staining, odors, presence of debris, etc. was accomplished by visual field observations.

6. Selection of sampling locations associated with the location of batteries identified just north of the lower pond.

7. Selection of sampling locations associated with professional judgement based on acceptable knowledge was accomplished by:

- Source and location of release

- Chemical nature and fate properties

- Physical transport pathways and properties

- Transport drivers 


\section{Criteria 2:}

All samples were analyzed using the analytical methods listed in Table 3-2 and Table 3-3 of the CAIP and for the chemical and radiological parameters listed in Table 3-4 of the CAIP. Samples were submitted for all of the analytical methods specified in the analytical program of the CAIP. Sixty-two samples were collected and each analyzed for the following analysis:

- Total VOCs

- Total SVOCs

- PCBs

- Metals

- TPH-DRO

- TPH-GRO

- Gamma Spectroscopy

- Isotopic Uranium

- Isotopic Plutonium

- Strontium-90

Sample results were assessed against the DQI of sensitivity as defined in the Industrial Sites QAPP (NNSA/NV, 2002). The sensitivity goal defined in the CAIP is that analytical detection limits will be less than the corresponding action level. This goal was not achieved for the analytical results listed in Table B.1-1. Results not meeting the sensitivity goal will not be used in making DQO decisions and will therefore be considered as rejected data. The impact on DQO decisions is addressed in the assessment of completeness.

\section{Criteria 3:}

To satisfy the third criteria, the entire dataset, as well as individual sample results, were assessed against the DQIs of precision, accuracy, comparability, completeness, and representativeness, as defined in the Industrial Sites QAPP (NNSA/NV, 2002). The DQI goals were presented in Table 6-1 of the CAIP. As presented in Table B.1-1 through Table B.1-3, these goals were met for each the DQIs. 
Table B.1-1

Chemical Analytes Failing Sensitivity Criteria

\begin{tabular}{|c|c|c|c|c|}
\hline Sample Number & Parameter & Result & Units & Final Action Level \\
\hline 552B059 & 1,2,3-Trichloropropane & $29(U)$ & $\mu \mathrm{g} / \mathrm{kg}$ & 11 \\
\hline 552B063 & Benzo(a)Pyrene & $270(U)$ & $\mu \mathrm{g} / \mathrm{kg}$ & 210 \\
\hline 552B058 & Benzo(a)Pyrene & $250(U)$ & $\mu \mathrm{g} / \mathrm{kg}$ & 210 \\
\hline 552B051 & Benzo(a)Pyrene & $290(U)$ & $\mu \mathrm{g} / \mathrm{kg}$ & 210 \\
\hline 552B043 & Benzo(a)Pyrene & $270(U)$ & $\mu \mathrm{g} / \mathrm{kg}$ & 210 \\
\hline 552B041 & Benzo(a)Pyrene & $250(U)$ & $\mu \mathrm{g} / \mathrm{kg}$ & 210 \\
\hline 552B037 & Benzo(a)Pyrene & $290(U)$ & $\mu \mathrm{g} / \mathrm{kg}$ & 210 \\
\hline 552B035 & Benzo(a)Pyrene & $280(U)$ & $\mu \mathrm{g} / \mathrm{kg}$ & 210 \\
\hline 552B032 & Benzo(a)Pyrene & $250(U)$ & $\mu \mathrm{g} / \mathrm{kg}$ & 210 \\
\hline 552B063 & Dibenzo(a,h)Anthracene & $270(U)$ & $\mu \mathrm{g} / \mathrm{kg}$ & 210 \\
\hline 552B058 & Dibenzo(a,h)Anthracene & $250(U)$ & $\mu \mathrm{g} / \mathrm{kg}$ & 210 \\
\hline 552B051 & Dibenzo(a,h)Anthracene & $290(U)$ & $\mu \mathrm{g} / \mathrm{kg}$ & 210 \\
\hline $552 \mathrm{~B} 043$ & Dibenzo(a,h)Anthracene & $270(U)$ & $\mu \mathrm{g} / \mathrm{kg}$ & 210 \\
\hline 552B041 & Dibenzo(a,h)Anthracene & $250(U)$ & $\mu \mathrm{g} / \mathrm{kg}$ & 210 \\
\hline 552B037 & Dibenzo(a,h)Anthracene & $290(U)$ & $\mu \mathrm{g} / \mathrm{kg}$ & 210 \\
\hline 552B035 & Dibenzo(a,h)Anthracene & $280(U)$ & $\mu \mathrm{g} / \mathrm{kg}$ & 210 \\
\hline 552B032 & Dibenzo(a,h)Anthracene & $250(U)$ & $\mu \mathrm{g} / \mathrm{kg}$ & 210 \\
\hline $552 \mathrm{~B} 037$ & N-Nitroso-Di-N-Propylamine & $340(U)$ & $\mu \mathrm{g} / \mathrm{kg}$ & 250 \\
\hline 552B037 & Americium-241 & $-1.8(U)$ & $\mathrm{pCi} / \mathrm{g}$ & 12.7 \\
\hline
\end{tabular}

$\mu \mathrm{g} / \mathrm{kg}=$ Micrograms per kilogram

$\mathrm{pCi} / \mathrm{g}=$ Picocuries per gram

\section{$\underline{\text { Precision }}$}

The RPD is applicable when both the sample and its duplicate have concentrations of the target radionuclide exceeding five times their minimum detectable concentration. This excludes many measurements because the samples contain non-detectable or low levels of the target radionuclide. In situations where the RPD does not apply, duplicate results are evaluated using the normalized difference (ND). 
The duplicate precision is evaluated using the RPD or ND. For the purpose of determining the data precision of sample analyses, environmental soil samples were evaluated and incorporated into the precision calculation. Table B.1-2 provides the precision analysis results for all constituents that were qualified for precision. The only constituents qualified for precision were lead, $\mathrm{Pu}-238$, and Pu-239.

As shown inTable B.1-2, the precision rates for the measurements of $\mathrm{Pu}-238, \mathrm{Pu}-239$, and lead are above the CAIP acceptance criteria of 80 percent. The precision rate for all other constituents is 100 percent. Therefore, the dataset is determined to be acceptable for the DQI of precision as all criteria were met.

Table B.1-2

Precision Measurements

\begin{tabular}{|c|c|c|c|c|c||}
\hline Parameter & $\begin{array}{c}\text { CAS } \\
\text { Number }\end{array}$ & User Test Panel & $\begin{array}{c}\text { Number of } \\
\text { Analytes } \\
\text { Qualified }\end{array}$ & $\begin{array}{c}\text { Number of } \\
\text { Measurements } \\
\text { Performed }\end{array}$ & $\begin{array}{c}\text { Percent } \\
\text { within } \\
\text { Criteria }\end{array}$ \\
\hline \hline Plutonium-238 & $13981-16-3$ & UGTAISOPU & 5 & 63 & 92.1 \\
\hline Plutonium-239 & $15117-48-3$ & UGTAISOPU & 6 & 63 & 90.5 \\
\hline Lead & $7439-92-1$ & EPA6010 & 7 & 62 & 88.7 \\
\hline
\end{tabular}

CAS $=$ Chemical Abstract Service

$\mathrm{EPA}=$ U.S. Environmental Protection Agency, SW-846 methods (EPA, 1990 and 2002)

\section{Accuracy}

For the purpose of determining data accuracy of sample analyses, environmental soil samples were evaluated and incorporated into the accuracy calculation. As shown in Table B.1-3, all accuracy rates are above 80 percent, with the exception of lead and barium.

The results qualified for accuracy were associated with matrix spike recoveries that were outside control limits and could potentially be reported at concentrations lower or higher than actual concentrations. All 19 lead results qualified for accuracy were associated with a matrix spike recovery that exceeded the upper limits. This would indicate that the associated samples may have been reported at concentrations higher than actual. This inaccuracy could impact a DQO decision by causing a false positive decision error. However, this did not occur at CAU 552 because no lead 
results exceeded the FAL. Therefore, the lead results that were qualified for reasons of accuracy can be confidently used to support DQO decisions.

Of the 26 barium results qualified for accuracy, 19 were associated with a matrix spike recovery that exceeded the upper limits. This would indicate that the associated samples may have been reported at concentrations higher than actual. This inaccuracy could impact a DQO decision by causing a false positive decision error. However, this did not occur at CAU 552 because no barium results exceeded the FAL. Seven of the barium results qualified for accuracy were associated with a matrix spike recovery that was below the limits. This would indicate that the associated samples may have been reported at concentrations lower than actual. However, there is negligible potential impact to DQO decisions for these seven barium results because the reported values are very small in comparison to the action levels (the FAL is 272 times higher than the highest reported barium concentration). Therefore, the barium results that were qualified for reasons of accuracy can be confidently used to support DQO decisions.

Table B.1-3

Accuracy Measurements

\begin{tabular}{|c|c|c|c|c|c||}
\hline Parameter & $\begin{array}{c}\text { CAS } \\
\text { Number }\end{array}$ & User Test Panel & $\begin{array}{c}\text { Number of } \\
\text { Analytes } \\
\text { Qualified }\end{array}$ & $\begin{array}{c}\text { Number of } \\
\text { Measurements } \\
\text { Performed }\end{array}$ & $\begin{array}{c}\text { Percent } \\
\text { within } \\
\text { Criteria }\end{array}$ \\
\hline \hline Methylene Chloride & $75-09-2$ & EPA8260 & 1 & 62 & 98.4 \\
\hline Strontium-90 & $10098-97-2$ & SR7500 & 10 & 63 & 84.1 \\
\hline Lead & $7439-92-1$ & EPA6010 & 19 & 62 & 69.4 \\
\hline Barium & $7440-39-3$ & EPA6010 & 26 & 62 & 58.1 \\
\hline
\end{tabular}

CAS $=$ Chemical Abstract Service

$E P A=$ U.S. Environmental Protection Agency, SW-846 methods (EPA, 1999 and 2002)

\section{$\underline{\text { Representativeness }}$}

The DQO process as identified in Appendix A of the CAIP was used to address sampling and analytical requirements for CAU 552. During this process, appropriate locations were selected that enabled the samples collected to be representative of the population parameters identified in the DQO (the most likely locations to contain contamination and locations that bound COCs). The sampling 
locations identified in the Criteria 1 discussion meet this criteria. Therefore, the analytical data acquired during the CAU $552 \mathrm{CAI}$ are considered representative of the population parameters.

\section{Comparability}

Field sampling, as described in the CAU 552 CAIP (NNSA/NSO, 2005), was performed and documented in accordance with approved procedures that are comparable to standard industry practices. Approved analytical methods and procedures per DOE were used to analyze, report, and validate the data. These are comparable to other methods used not only in industry and government practices, but most importantly are comparable to other investigations conducted for the NTS. Therefore, datasets within this project are considered comparable to other datasets generated using these same standardized DOE procedures, thereby meeting DQO requirements.

Also, standard, approved field and analytical methods ensured that data were appropriate for comparison to the investigation action levels specified in the CAIP.

\section{Completeness}

The CAU 552 CAIP (Table 6-1) defines acceptable criteria for nature completeness to be 80 percent of possible analytes identified in the CAIP having valid results and 90 percent of suspected analytes (including Decision II samples) having valid results. Also, the data must be of sufficient high quality so as to be able to make the DQO decisions.

There were no rejected data for environmental samples collected and analyzed for CAU 552. All data for critical analytes were 100 percent complete; thus, the dataset is acceptable. Table B.1-1 provides the rejected data failing the criteria for sensitivity. The rejected data were not needed to define the presence or extent of COC within CAU 552.

\section{B.1.1.2 DQO Provisions to Limit False Positive Decision Error}

The false positive decision error was controlled by assessing the potential for false positive analytical results. Quality assurance/QC samples such as field blanks, trip blanks, laboratory control samples, and method blanks were used to determine whether a false positive analytical result may have occurred. Of $42 \mathrm{QA} / \mathrm{QC}$ samples submitted, no false positive analytical results were detected. 
Proper decontamination of sampling equipment and the use of certified clean sampling equipment and containers also minimized the potential for cross contamination that could lead to a false positive analytical result.

\section{B.1.1.2 Decision II Decision Rules}

The population parameter for Decision II data is be the observed concentration of each unbounded COC in any sample.

- If the observed concentration of any COC in a Decision II sample exceeds the FALs, then additional samples will be collected to complete the determination of the extent.

- If observed COC concentrations in a sample from all bounding directions are less than the FALs, then the decision will be that the extent of contamination has been defined in the lateral and/or vertical direction.

\section{B.1.1.2.1 DQO Provisions to Limit False Negative Decision Error}

A false negative decision error (where consequences are more severe) is controlled by meeting the following criteria:

1. Having a high degree of confidence that the sample locations selected will identify the extent of the COCs.

2. Having a high degree of confidence that analyses conducted will be sufficient to detect any COCs present in the samples.

3. Having a high degree of confidence that the dataset is of sufficient quality and completeness to be able to evaluate corrective action alternatives.

\section{Criteria 1:}

The following criteria (stipulated in the CAU 552 DQOs [NNSA/NSO, 2005]) were used in selecting Decision II sample locations.

- Selection of sampling locations associated with vertical extent was accomplished by the depth sequences used during the Decision I sampling.

- Lateral extent of contamination was determined through Decision II sampling of the pond berms and natural drainages. 


\section{Criteria 2:}

All samples were analyzed for the Cs-137 (the only COC present).

The criterion for sensitivity was accomplished for all analyses as demonstrated in Table B.1-1.

\section{Criteria 3:}

To satisfy the third criteria for extent, the entire dataset, as well as individual sample results, were assessed against the DQIs of precision, accuracy, comparability, completeness, and representativeness, as defined in the Industrial Sites QAPP (NNSA/NV, 2002). The DQI discussion is presented under Criteria 3 for Decision I.

\section{B.1.1.2.2 DQO Provisions to Limit False Positive Decision Error}

The false positive decision error was controlled by assessing the potential for false positive analytical results. Quality assurance/QC samples such as field blanks, trip blanks, laboratory control samples, and method blanks were used to determine if a false positive analytical result may have occurred. Of 42 QA/QC samples submitted, no false positive analytical results were detected.

Proper decontamination of sampling equipment and the use of certified clean sampling equipment and containers also minimized the potential for cross contamination that could lead to a false positive analytical result.

\section{B.1.2 Conduct a Preliminary Data Review}

A preliminary data review was conducted by reviewing QA reports and inspecting the data. The contract analytical laboratories generate a QA report when data quality does not meet contractual requirements. All data received form the analytical laboratories met contractual requirements and a QA report was not generated. Data were validated and verified to ensure that the measurement systems performed in accordance with the criteria specified and that the validated dataset quality is satisfactory. 


\section{B.1.3 Select the Test and Identify Key Assumptions}

The test for making DQO Decision I was the comparison of the maximum analyte result from each CAS to the corresponding FAL. The test for making DQO Decision II was the comparison of all $\mathrm{COC}$ analyte results from each bounding sample to the corresponding FALs.

The key assumptions that could impact a DQO decision are listed in Table B.1-4.

\section{B.1.4 Verify the Assumptions}

The results of the investigation support the key assumptions identified in the CAU 552 DQOs and Table B.1-4 except as listed below:

All data collected during the CAI supported CSM.

\section{B.1.5 Results}

This section resolves the two DQO decisions for CAU 552, CAS 12-23-05.

\section{B.1.5.1 Decision I Decision Rules}

Decision Rule: If the concentration of any COPC in a target population exceeds the FAL for that COPC during the initial investigation, then that COPC is identified as a COC and Decision II sampling will be conducted.

Result: In CAS 12-23-05, Cs-137 exceeded the FAL.

Decision Rule: If all COPC concentrations are less than the corresponding PALs, then the decision will be no further action.

Result: Cs-137 was identified above FALs; therefore, no further action is not applicable.

\section{B.1.5.2 Decision II Decision Rules}

Decision Rule: If the observed concentration of any COC in a Decision II sample exceeds the PALs, then additional samples will be collected to complete the determination of the extent. 
Table B.1-4

\section{Key Assumptions}

\begin{tabular}{|c|c|}
\hline Exposure Scenario & $\begin{array}{l}\text { Site workers are only exposed to contaminants of concern (COCs) through oral } \\
\text { ingestion, inhalation, external exposure to radiation, or dermal contact (by absorption) } \\
\text { of COCs absorbed onto the soils. } \\
\text { Exposure to contamination is limited to industrial site workers, } \\
\text { construction/remediation workers, and military personnel conducting training. } \\
\text { The investigation results did not reveal any potential exposures other than those } \\
\text { identified in the conceptual site models (CSMs). }\end{array}$ \\
\hline Affected Media & $\begin{array}{l}\text { Surface soil, shallow subsurface soil, and potentially perched (shallow) groundwater. } \\
\text { Deep groundwater contamination is not a concern. } \\
\text { Contaminants migrating to regional aquifers are not considered. } \\
\text { The investigation results did not reveal any affected media other than those identified } \\
\text { in the CSMs. }\end{array}$ \\
\hline $\begin{array}{l}\text { Location of } \\
\text { Contamination/Release Points }\end{array}$ & $\begin{array}{l}\text { The area of contamination is contiguous. } \\
\text { The extent of COC concentration decreases away from the area of contamination. } \\
\text { The investigation results did not reveal any locations of contamination or release } \\
\text { points other than those identified in the CSMs. }\end{array}$ \\
\hline Transport Mechanisms & $\begin{array}{l}\text { Surface transport may occur as a result of a spill or storm water runoff. } \\
\text { Surface transport beyond shallow substrate is not a concern. } \\
\text { The investigation results did not reveal any transport mechanisms other than those } \\
\text { identified in the CSMs. }\end{array}$ \\
\hline Preferential Pathways & $\begin{array}{l}\text { None. } \\
\text { The investigation results did not reveal any preferential pathways other than those } \\
\text { identified in the CSMs. }\end{array}$ \\
\hline $\begin{array}{l}\text { Lateral and Vertical Extent of } \\
\text { Contamination }\end{array}$ & $\begin{array}{l}\text { Subsurface contamination, if present, is contiguous and decreases with distance and } \\
\text { depth from the source. } \\
\text { Surface contamination may occur laterally as a result of a spill or storm water runoff. } \\
\text { The investigation results did not reveal any lateral and vertical extent of contamination } \\
\text { other than those identified in the CSMs. }\end{array}$ \\
\hline Groundwater Impacts & $\begin{array}{l}\text { None. } \\
\text { The investigation results did not reveal groundwater impacts other than those } \\
\text { identified in the CSMs. }\end{array}$ \\
\hline Future Land Use & $\begin{array}{l}\text { Nonresidential. } \\
\text { The investigation results did not reveal any future land uses other than those identified } \\
\text { in the CSMs. }\end{array}$ \\
\hline
\end{tabular}

\section{UNCONTROLLED when Printed}


Result: Decision II samples were collected on the berms of the ponds and in natural storm drainages to the east of the ponds.

Decision Rule: If all observed COC population parameters are less than the PALs, then the decision will be that the extent of contamination has been defined in the lateral and/or vertical direction.

Result: The contamination at CAS 12-23-05 was found to be confined within the upper pond. 


\section{B.2.0 References}

EPA, see U.S. Environmental Protection Agency.

NNSA/NSO, see U.S. Department of Energy, National Nuclear Security Administration Nevada Site Office.

NNSA/NV, see U.S. Department of Energy, National Nuclear Security Administration, Nevada Operations Office.

U.S. Department of Energy, National Nuclear Security Administration Nevada Site Office. 2005. Corrective Action Investigation Plan for Corrective Action Unit 554: Area 23 Release Site, Nevada Test Site, Nevada, Rev. 0, DOE/NV--1010. Las Vegas, NV.

U.S. Department of Energy, National Nuclear Security Administration, Nevada Operations Office. 2002. Industrial Sites Quality Assurance Project Plan, Nevada Test Site, Nevada, Rev. 3, DOE/NV--372. Las Vegas, NV.

U.S. Environmental Protection Agency. 1998. Guidelines for Data Quality Assessment: Practical Methods for Data Analysis, EPA 600/R-96/084.

U.S. Environmental Protection Agency. 1999. Contract Laboratory Program National Functional Guidelines for Organic Data Review, EPA 540/R-99/008.

U.S. Environmental Protection Agency. 2002. Contract Laboratory Program National Functional Guidelines for Inorganic Data Review, EPA 540/R-01/-008 


\section{Appendix C}

\section{Risk Assessment for CAU 552}




\section{C.1.0 Risk-Based Corrective Action Process}

This section contains documentation of the ASTM Method E1739-95 risk-based corrective action process as applied to CAU 552 (ASTM, 1995). Method E1739-95 defines three tiers (or levels) in evaluating DQO decisions involving increasingly sophisticated analyses.

- Tier 1 - Sample results from source areas (highest concentrations) compared to preliminary action levels (PALs) based on generic (non-site-specific) conditions.

- Tier 2 - Sample results from exposure points compared to site-specific target levels (SSTLs) calculated using site-specific inputs and Tier 1 formulas (from the ASTM procedure).

- Tier 3 - Sample results from exposure points compared to SSTLs and points of compliance calculated using chemical fate/transport and probabilistic modeling.

The risk-based corrective action decision process stipulated in ASTM Method E1739-95 is summarized in Figure C.1-1.

\section{C.1.1 Scenario}

Corrective Action Unit 552, Area 12 Muckpile and Ponds, consists of one site, CAS 12-23-05, Ponds, located directly east of the G-Tunnel muckpile. The CAS consists of three ponds, formerly used to collect effluent from the U12g tunnel during drilling and weapons testing activities. Five documented nuclear tests were conducted inside G-Tunnel over a period of nine years, beginning in 1962. The effluent was the result of encountering saturated fractures and perched water during tunnel construction and drillback activities. For more information on site history, refer to the CAU 552 CAIP (NNSA/NSO, 2005).

\section{C.1.2 Site Assessment}

Corrective Action Unit 552 was investigated by collecting both surface and subsurface soil samples, as well as one sample of standing liquid within the upper pond. Surface samples were collected via drilling or hand methods. Subsurface soil samples were obtained using either drilling or hand-auger methods. Investigation intervals and soil samples were field screened for VOCs and alpha and beta/gamma radiation. The field screening results were compared against screening 


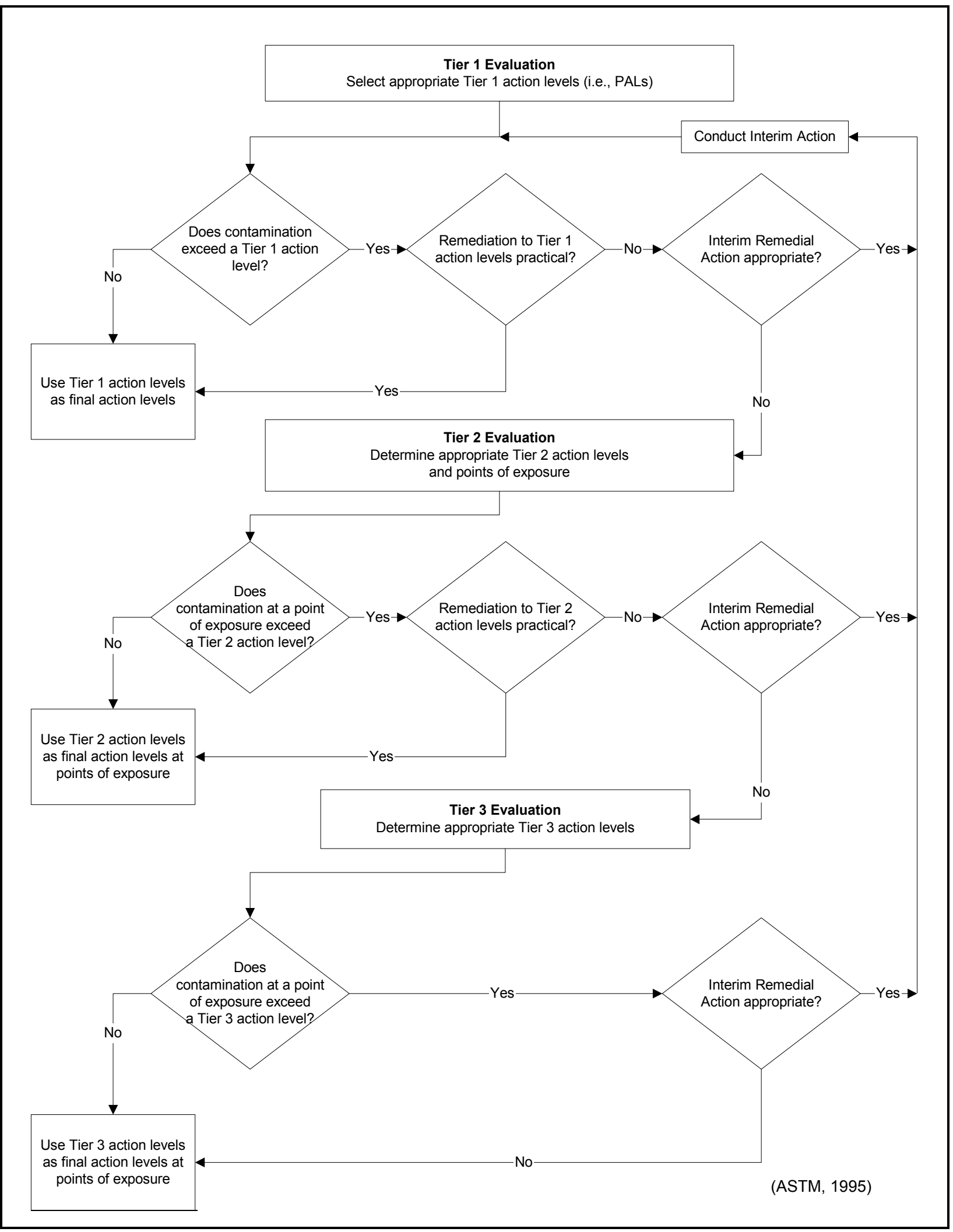

Figure C.1-1

ASTM Method E1739-95 Risk-Based Corrective Action Decision Process 
levels to help guide the investigation. Resultant samples, both above and below screening levels, were shipped to off-site laboratories to be analyzed for appropriate chemical and radiological parameters. These readings were also used to guide sampling decisions and H\&S controls.

Surface and subsurface soil samples were collected at random and biased sampling locations, as outlined in the CAIP. A total of 66 soil samples were sent to the laboratory for analysis for the full suite of analytes defined in the CAIP. Analytical results show that seven samples contain TPH-DRO above the PAL of 100 ppm and seven samples that contain Cs-137 in concentrations above the PAL of $7.3 \mathrm{pCi} / \mathrm{g}$.

A data summary of data obtained from the CAI is presented in Section 2.2.1. The maximum detected concentrations of all constituents detected above reporting limits are presented in Table C.1-1.

\section{C.1.3 Site Classification and Initial Response Action}

Table 1 in the ASTM Standard provides a classification scheme to determine the appropriate site classifications. The four major classifications are: (1) immediate threat to human health, safety, and the environment; (2) short-term (0 to 2 years) threat to human health, safety, and the environment; (3) long-term (greater than 2 years) threat to human health, safety, or the environment; and (4) no demonstrated long-term threats.

Corrective Action Site 12-23-05 contains shallow surface soil radiological contamination. Based on this data, CAS 12-23-05 was determined to be a classification site. No initial response actions are necessary at this site, beyond the closure actions that have already been completed.

\section{C.1.4 Development of Tier 1 Look-Up Table of Risk-Based Screening Level Selection}

- Tier 1 action levels were defined as the PALs established during the DQO process. The PALs are a tabulation of chemical-specific (but not site-specific) screening levels based on the type of media (soil) and potential exposure scenarios (industrial). These are very conservative estimates of risk, are preliminary in nature, and are used as action levels for site screening purposes. Although the PALs are not intended to be used as FALs, a FAL may be defined as the Tier 1 action level (i.e., PAL) value if individual constituent analytical results are below the corresponding Tier 1 action level 
Table C.1-1

Maximum Detected Concentrations

\begin{tabular}{|c|c|c|c|c|}
\hline Sample ID & Parameter & Result & PAL & Units \\
\hline 552B026 & Acetone & 13 & 61,000 & $\mu \mathrm{g} / \mathrm{kg}$ \\
\hline 552B026 & Methylene Chloride & 4.1 & 21,000 & $\mu \mathrm{g} / \mathrm{kg}$ \\
\hline 552B011 & Total-Xylenes & 9.4 & 420,000 & $\mu \mathrm{g} / \mathrm{kg}$ \\
\hline 552B035 & Arsenic & 3.43 & 23 & $\mathrm{mg} / \mathrm{kg}$ \\
\hline 552B035 & Barium & 922 & 67,000 & $\mathrm{mg} / \mathrm{kg}$ \\
\hline 552B051 & Beryllium & 2.4 & 1,900 & $\mathrm{mg} / \mathrm{kg}$ \\
\hline 552B037 & Cadmium & 0.624 & 450 & $\mathrm{mg} / \mathrm{kg}$ \\
\hline 552B014 & Chromium & 2.69 & 450 & $\mathrm{mg} / \mathrm{kg}$ \\
\hline 552B048 & Lead & 229 & 750 & $\mathrm{mg} / \mathrm{kg}$ \\
\hline 552B051 & Silver & 1.05 & 5,100 & $\mathrm{mg} / \mathrm{kg}$ \\
\hline 552B048 & TPH-DRO & 230 & 100 & $\mathrm{mg} / \mathrm{kg}$ \\
\hline 552B032 & TPH-GRO & 1.9 & 100 & $\mathrm{mg} / \mathrm{kg}$ \\
\hline 552B061 & Actinium-228 & 3.24 & $5 / 15$ & $\mathrm{pCi} / \mathrm{g}$ \\
\hline 552B048 & Americium-241 & 1.17 & 12.7 & $\mathrm{pCi} / \mathrm{g}$ \\
\hline 552B015 & Bismuth-212 & 5.4 & $5 / 15$ & $\mathrm{pCi} / \mathrm{g}$ \\
\hline 552B045 & Bismuth-214 & 1.59 & $5 / 15$ & $\mathrm{pCi} / \mathrm{g}$ \\
\hline 552B037 & Cesium-137 & 189 & 12.2 & $\mathrm{pCi} / \mathrm{g}$ \\
\hline 552B037 & Cobalt-60 & 0.98 & 2.7 & $\mathrm{pCi} / \mathrm{g}$ \\
\hline 552B061 & Lead-212 & 4.05 & $5 / 15$ & $\mathrm{pCi} / \mathrm{g}$ \\
\hline 552B043 & Lead-214 & 1.68 & $5 / 15$ & $\mathrm{pCi} / \mathrm{g}$ \\
\hline 552B063 & Thallium-208 & 1.13 & $5 / 15$ & $\mathrm{pCi} / \mathrm{g}$ \\
\hline 552B028 & Thorium-234 & 4.2 & 63.2 & $\mathrm{pCi} / \mathrm{g}$ \\
\hline 552B037 & Plutonium-238 & 1.5 & 13 & $\mathrm{pCi} / \mathrm{g}$ \\
\hline 552B037 & Plutonium-239 & 4.36 & 12.7 & $\mathrm{pCi} / \mathrm{g}$ \\
\hline 552B037 & Strontium-90 & 19 & 838 & $\mathrm{pCi} / \mathrm{g}$ \\
\hline 552B061 & Uranium-234 & 3.33 & 143 & $\mathrm{pCi} / \mathrm{g}$ \\
\hline 552B055 & Uranium-235 & 0.157 & 17.5 & $\mathrm{pCi} / \mathrm{g}$ \\
\hline 552B061 & Uranium-238 & 1.84 & 105 & $\mathrm{pCi} / \mathrm{g}$ \\
\hline
\end{tabular}


value. The FAL may also be established as the Tier 1 action level value if individual constituent analytical results exceed the corresponding Tier 1 action level value and implementing a corrective action based on the FAL is practical. The PALs are defined as:

- EPA Region 9 Risk-Based Preliminary Remediation Goals (PRGs) for Industrial Soils (2002).

- Background concentrations for RCRA metals will be evaluated when natural background exceeds the PAL, as is often the case with arsenic. Background is considered the mean plus two times the standard deviation of the mean based on data published in Mineral and Energy Resource Assessment of the Nellis Air Force Range (NBMG, 1998; Moore, 1999).

- $\mathrm{TPH}$ concentrations above the action level of $100 \mathrm{mg} / \mathrm{kg}$ per NAC 445A.2272 (NAC, 2003).

- For COPCs without established PRGs, a protocol similar to EPA Region 9 will be used to establish an action level; otherwise, an established PRG from another EPA region may be chosen.

- The PALs for material, equipment, and structures with residual surface contamination are the allowable total residual surface contamination values for unrestricted release of material and equipment listed in the DOE Order 5400.5 (DOE, 1993), which is also Table 4-2 of the NV/YMP Radcon Manual (DOE/NV, 2000).

- The PALs for radioactive contaminants are based on the NCRP Report No. 129 recommended screening limits for construction, commercial, industrial land-use scenarios (NCRP, 1999) at a $25 \mathrm{mrem} / \mathrm{yr}$ dose constraint (Appenzeller-Wing, 2004) and the generic guidelines for residual concentration of radionuclides in DOE Order 5400.5 (DOE, 1993).

The PALs were developed based on an industrial scenario. As the site is considered an industrial site (no residential allowed) the use of industrial soil PALs is appropriate. Therefore, the Tier 1 lookup table consists of the PAL concentrations or activities defined in the CAIP.

\section{C.1.5 Exposure Pathway Evaluation}

The DQOs stated that site workers would only be exposed to COCs through oral ingestion, inhalation, or dermal contact (by absorption) due to inadvertent disturbance of these materials. The investigation demonstrated that these are the only potential exposure routes, as contamination was confined to soils within the upper pond. With the use restriction presented in this report in place, 
access to the upper pond will be limited to industrial workers during a future remediation of the site. Considerations of the potential for contaminants to impact groundwater are presented in Section C.3.0.

\section{C.1.6 Comparison of Site Conditions with Tier 1 Risk-Based Screening Levels}

All analytical results from CAU 552 samples were less than corresponding Tier 1 action levels except for Cs-137 and TPH-DRO. A Tier 2 evaluation of radionuclides (RESRAD) was not appropriate because the ponds will still receive potential contaminated effluent from the muckpile. Results from TPH-DRO analyses demonstrated the presence of TPH-DRO exceeding the PAL of $100 \mathrm{mg} / \mathrm{kg}$ in seven soil samples.

\section{C.1.7 Evaluation of Tier 1 Results}

For analytes other than TPH-DRO, the Tier 1 action levels were used to establish the FALs. It was determined that no further evaluation is required for these constituents.

\section{C.1.8 Tier 1 Remedial Action Evaluation}

No actions to remediate the site to Tier 1 action levels for TPH-DRO are proposed. Therefore, these contaminants were passed on to a Tier 2 evaluation. Cesium-137 contamination will not be remediated at this time due to the continued presence of the source of contamination, the muckpile.

\section{C.1.9 Tier 2 Evaluation}

No additional data was needed to complete a Tier 2 evaluation.

\section{C.1.9.1 Development of Tier 2 Table of Site-Specific Target Levels}

\section{Evaluation of TPH-DRO SSTLS}

Although Tier 2 action levels are generally calculated using site-specific inputs and general risk formulas (such as those used to calculate the PALs), the Tier 2 action levels selected for the TPH-DRO evaluation are the EPA Region 92002 Preliminary Remediation Goals (PRGs) (EPA, 2002). 
Method E1739-95 stipulates that risk evaluations for TPH-DRO contamination be calculated and evaluated based on the risk posed by the specific potentially hazardous constituents represented by a TPH-DRO measurement. Section 6.4.3 ("Use of Total Petroleum Hydrocarbon Measurements") of Method E1739-95 states: "TPHs should not be used for risk assessment because the general measure of TPH-DRO provides insufficient information about the amounts of individual chemical(s) of concern present" (see also Sections X1.5.4 and X1.42 of Method E1739-95). Therefore, the individual potentially hazardous constituents in TPH-DRO were compared to corresponding Tier 2 SSTLs to evaluate the need for corrective action at CAU 552. The component SSTLs and maximum values reported at CAU 552 are presented in Table C.1-2.

Table C.1-2

Tier 2 SSTLs and CAU 552 Results for Hazardous Constituents of Diesel

\begin{tabular}{|c|c|c|c|c|c|c|}
\hline CAS No. & Common Name & ASTM E1739-95 & $\begin{array}{c}\text { SSTL } \\
\text { (mg/kg) }\end{array}$ & $\begin{array}{c}\text { Maximum } \\
\text { Reported } \\
\text { Value } \\
\text { (mg/kg) }\end{array}$ & $\begin{array}{c}\text { SSL } \\
(\mathrm{mg} / \mathrm{kg})\end{array}$ & $\begin{array}{l}\text { Analytical } \\
\text { Methods }\end{array}$ \\
\hline $108-67-8$ & 1,3,5-Trimethylbenzene & & 70 & ND & none & EPA8260 \\
\hline $91-57-6$ & 2-Methylnaphthalene ${ }^{a}$ & & 190 & ND & none & EPA8270 \\
\hline $56-55-3$ & Benz(a)anthracene & $x$ & 2.1 & ND & 2.0 & EPA8270 \\
\hline $71-43-2$ & Benzene & $x$ & 1.4 & ND & 0.03 & EPA8260 \\
\hline $50-32-8$ & Benzo(a)pyrene & $x$ & 0.21 & ND & 8.0 & EPA8270 \\
\hline $100-41-4$ & Ethylbenzene & $x$ & 400 & ND & 13 & EPA8260 \\
\hline $91-20-3$ & Naphthalene & $x$ & 190 & ND & 84 & EPA8270/8260 \\
\hline $108-88-3$ & Toluene & $x$ & 520 & ND & 12 & EPA8260 \\
\hline $1330-20-7$ & Total Xylenes ${ }^{b}$ & $x$ & 420 & 0.0094 & 210 & EPA8260 \\
\hline $104-51-8$ & n-Butylbenzene & & 240 & ND & none & EPA8270 \\
\hline $103-65-1$ & n-Propylbenzene & & 240 & ND & none & EPA8270 \\
\hline
\end{tabular}

\footnotetext{
${ }^{\mathrm{a}}$ Uses PRG for napthalene as surrogate

${ }^{\mathrm{b}}$ Total of $\mathrm{m}-, \mathrm{o}-$, and $\mathrm{p}$-xylenes

ASTM $=$ American Society for Testing and Materials

CAS $=$ Chemical Abstract Service

$\mathrm{CAU}=$ Corrective Action Unit

$\mathrm{EPA}=\mathrm{U} . \mathrm{S}$. Environmental Protection Agency

$\mathrm{FAL}=$ Final action level

$\mathrm{mg} / \mathrm{kg}=$ Milligrams per kilogram

$\mathrm{ND}=$ Nondetect

$\mathrm{SSL}=$ Soil screening level

SSTL $=$ Site-specific target level
} 


\section{C.1.10 Comparison of Site Conditions with Tier 2 Table SSTLs}

The Tier 2 action levels are normally compared to individual sample results from reasonable points of exposure (as opposed to the source areas as is done in Tier 1) on a point-by-point basis. Points of exposure are defined as those locations or areas at which an individual or population may come in contact with a contaminant of concern originating from a CAS. For CAU 552, the Tier 2 action levels were compared to maximum constituent concentrations from surface samples, representing reasonable points of exposure.

As shown in Table C.1-2, all analytical results for potentially hazardous constituents in TPH-DRO from CAU 552 were less than corresponding Tier 2 action levels. The FALs for these constituents were established as the Tier 2 SSTLs (i.e., EPA Region 9 PRGs).

\section{C.1.11 Tier 2 Remedial Action Evaluation}

It was determined that, based on risk to receptors, no further action is required for TPH-DRO constituents. As all contaminant Tier 1 or Tier 2 action levels, therefore, FALs were established based on a Tier 3 evaluation was not conducted. 


\section{C.2.0 Regulatory Basis}

The FFACO Part III, Section III.3 (FFACO, 1996) stipulates conformance with Chapter 445 of the NAC (NAC, 2003). Section NAC 445A.227 lists the factors to be considered in determining whether corrective action is required.

For sites where it is determined that corrective action is required (the corrective action process applies to all FFACO sites), Section NAC 445A.22705 stipulates a process to determine the necessary remediation standards (or FALs) based on an evaluation of the risk the site poses to public health and the environment.

Section NAC 445A.22705 states:

1. Except as otherwise provided in NAC 445A.22715, if an owner or operator is required to take corrective action pursuant to NAC 445A.227, the owner or operator may conduct an evaluation of the site, based on the risk it poses to public health and the environment, to determine the necessary remediation standards or to establish that corrective action is not necessary. Such an evaluation must be conducted using Method E1739-95, adopted by the ASTM, as it exists on October 3, 1996, or an equivalent method approved by the Division.

2. The Division shall determine whether an evaluation complies with the requirements of Method E1739-95, or an equivalent method of testing approved by the Division. The Division may reject, require revisions be made to, or withdraw its concurrence with the evaluation at any time after the completion of the evaluation for the following reasons:

a. The evaluation does not comply with the applicable requirements for conducting the evaluation.

b. Conditions at the site have changed.

c. New information or previously unidentified information that would alter the results of the evaluation becomes available and demonstrates that the release may have a detrimental impact on public health or the environment.

Therefore, in compliance with Section NAC 445A.22705, NNSA/NSO will "conduct an evaluation of the site, based on the risk it poses to public health and the environment, to determine the necessary remediation standards or to establish that corrective action is not necessary" using ASTM Method E1739-95. 


\section{C.3.0 References}

ASTM, see American Society for Testing and Materials.

American Society for Testing and Materials. 1995. Standard Guide for Risk-Based Corrective Action Applied at Petroleum Release Sites/American Society for Testing and Materials, Method E 1739-95 (Reapproved 2002). Philadelphia, PA.

Appenzeller-Wing, J., U.S. Department of Energy, National Nuclear Security Administration Nevada Site Office. 2004. Letter to T.A. Maize (NDEP) entitled, "Submittal of Proposed Radiological Preliminary Action Levels (PALs) for the Industrial Sites Project," 15 January. Las Vegas, NV.

DOE, see U. S. Department of Energy.

EPA, see U.S. Environmental Protection Agency.

FFACO, see Federal Facility Agreement and Consent Order.

Federal Facility Agreement and Consent Order. 1996 (as amended). Agreed to by the State of Nevada, the U.S. Department of Energy, and the U.S. Department of Defense.

Moore, J., Science Applications International Corporation. 1999. Memorandum to M. Todd (SAIC) entitled, "Background Concentrations for NTS and TTR Soil Samples," 03 February. Las Vegas, NV.

NAC, see Nevada Administrative Code.

NBMG, see Nevada Bureau of Mines and Geology.

NCRP, see National Council on Radiation Protection and Measurements.

NNSA/NSO, see U.S. Department of Energy, National Nuclear Security Administration Nevada Site Office.

NNSA/NV, see U.S. Department of Energy, Nevada Operations Office.

National Council on Radiation Protection and Measurements. 1999. Recommended Screening Limits for Contaminated Surface Soil and Review of Factors Relevant to Site-Specific Studies/National Council on Radiation Protection and Measurements, NCRP Report No. 129. Bethesda, MD.

Nevada Administrative Code. 2003. NAC 445A, "Water Controls." Carson City, NV. 
Nevada Bureau of Mines and Geology. 1998. Mineral and Energy Resource Assessment of the Nellis Air Force Range, Open File Report 98-1. Reno, NV.

U.S. Department of Energy. 1993. DOE Order 5400, Change 2, "Radiation Protection of the Public and the Environment." Washington, DC: U.S. Government Printing Office.

U.S. Department of Energy, National Nuclear Security Administration Nevada Site Office. 2005. Corrective Action Investigation Plan for Corrective Action Unit 552: Area 12 Muckpile and Ponds, Nevada Test Site, Nevada, Rev. 1, DOE/NV--962. Las Vegas, NV.

U.S. Department of Energy, Nevada Operations Office. 2000. NV/YMP Radiological Control Manual, DOE/NV--11718-079, Rev. 4. Prepared by Bechtel Nevada. Las Vegas, NV.

U.S. Environmental Protection Agency. 2002. Region 9 Preliminary Remediation Goals (PRGs). As accessed at http://www.epa.gov/region09/waste/sfund/prg/index.htm. 


\section{Appendix D}

\section{Closure Activity Summary for CAU 552}




\section{D.1.0 Closure Activity Summary}

This section provides details on the completed closure activities at CAU 552, Area 12 Muckpile and Ponds. Closure of the site with use restrictions was determined to be the recommended corrective action for this site due to the continued presence of the source of contamination. The existence of the source (G-Tunnel muckpile) presents a possibility for future contamination to be introduced into the ponds at CAS 12-23-05, therefore making clean closure of the site unfeasible.

The closure activities at CAU 552 included delineating the contaminated area (upper pond) with T-posts and wire, posted with proper radiological control signs, as well as removing the overflow piping connecting the upper pond to the two uncontaminated lower ponds, and enacting a use restriction on the contaminated area. The following sections describe the closure activities in detail.

\section{D.1.1 Use Restriction}

The area around the upper pond has been placed under a use restriction due to the presence and potential for future introduction of contaminants into the pond. The use restriction is outlined in Appendix C, and the area to be restricted is presented in Figure F.1-1 of this report. The use restriction includes delineation of the area with T-posts, wire, and radiological postings. An annual inspection of the area will be performed to ensure that demarcation and postings are in good condition and that all signs are legible.

\section{D.1.2 Removal of Current Site Features}

The following site features will be removed and disposed of as part of the closure activities:

- Overflow piping connecting the upper pond to the middle pond, and the overflow piping connecting the middle pond to the lower pond. The contamination found at the site was determined to be confined to the upper pond.

- Postings around the lower two ponds will be demarkated. All T-posts, fencing, ropes, and signs delineating the lower two ponds as radiologically controlled areas will be removed.

- Wire fencing around the upper pond will be modified to only include the upper pond. 


\section{D.1.3 Future Site Activities}

Corrective Action Unit 552 will be closed with a land use restriction due to the continued presence of the G-Tunnel muckpile, which acts as the source of contamination at this site. Annual inspections of the use restricted area (upper pond) are outlined in Appendix C. Clean closure of the site is not feasible under current conditions, because there is a distinct possibility that contamination will migrate from the muckpile into the upper pond during large rain events in the future. However, the site should be revisited once the corrective action investigation of the G-Tunnel muckpile has been completed and the source of contamination is controlled. At such a time, the CAU 552 investigation may be revisited and appropriate corrective actions can be recommended. 


\section{Appendix E \\ Sample Location Coordinates for CAU 552}




\section{E.1.0 Sample Location Coordinates}

Sample location coordinates were collected during the corrective action investigation using a Trimble GPS, Model TSCI. These coordinates identify the field-sampling locations (e.g., latitude, longitude, elevation) at CAU 552, CAS 12-23-05.

Sample locations and pertinent locations of interest at are shown on Figure A.2-1 The corresponding coordinates for CAS 12-23-05 sample locations are listed in Table E.1-1.

Table E.1-1

Sample Location Coordinates and Locations of Interest for CAS 12-23-05 (Page 1 of 2)

\begin{tabular}{|c|c|c|c|c|}
\hline Location & Latitude & Longitude & Northing $^{a}$ & Easting $^{a}$ \\
\hline B01 & 37.168601887 & -116.188978895 & 4113680.476 & 572004.243 \\
\hline B02 & 37.168752496 & -116.189069138 & 4113697.116 & 571996.088 \\
\hline B03 & 37.168543576 & -116.189116781 & 4113673.903 & 571992.056 \\
\hline B04 & 37.168604879 & -116.189123438 & 4113680.698 & 571991.407 \\
\hline B05 & 37.168827263 & -116.18921915 & 4113705.296 & 571982.699 \\
\hline B06 & 37.168591581 & -116.18930264 & 4113679.087 & 571975.51 \\
\hline B07 & 37.168685041 & -116.189436361 & 4113689.354 & 571963.549 \\
\hline B08 & 37.168506303 & -116.190178384 & 4113668.962 & 571897.838 \\
\hline B09 & 37.168790472 & -116.189918213 & 4113700.684 & 571920.668 \\
\hline B11 & 37.16844241 & -116.189685985 & 4113662.247 & 571941.616 \\
\hline B12 & 37.168717153 & -116.189649301 & 4113692.754 & 571944.613 \\
\hline B13 & 37.168908315 & -116.186373391 & 4113716.452 & 572235.278 \\
\hline B14 & 37.169129266 & -116.185413075 & 4113741.695 & 572320.328 \\
\hline B15 & 37.169112319 & -116.184740766 & 4113740.328 & 572380.034 \\
\hline BB01 & 37.168591092 & -116.189076736 & 4113679.204 & 571995.567 \\
\hline BB02 & 37.168768516 & -116.189220914 & 4113698.778 & 571982.598 \\
\hline BR01 & 37.168637666 & -116.18908622 & 4113684.364 & 571994.68 \\
\hline BR02 & 37.168746607 & -116.189369034 & 4113696.235 & 571969.468 \\
\hline BR03 & 37.168623989 & -116.189252579 & 4113682.72 & 571979.923 \\
\hline BR04 & 37.168755159 & -116.189276735 & 4113697.254 & 571977.654 \\
\hline BR05 & 37.168660423 & -116.18934047 & 4113686.695 & 571972.086 \\
\hline
\end{tabular}


Table E.1-1

Sample Location Coordinates and Locations of Interest for CAS 12-23-05 (Page 2 of 2)

\begin{tabular}{||c||c|c|c|c|}
\hline Location & Latitude & Longitude & Northing & Easting $^{\mathrm{a}}$ \\
\hline BR06 & 37.168478205 & -116.189629906 & 4113666.261 & 571946.561 \\
\hline BR07 & 37.168589227 & -116.18968284 & 4113678.537 & 571941.756 \\
\hline BR08 & 37.168549673 & -116.189982835 & 4113673.922 & 571915.159 \\
\hline BR09 & 37.168623988 & -116.189579124 & 4113682.472 & 571950.931 \\
\hline BR10 & 37.168572294 & -116.189899423 & 4113676.495 & 571922.543 \\
\hline BR11 & 37.168511873 & -116.189703785 & 4113669.94 & 571939.97 \\
\hline BR12 & 37.168587621 & -116.190192801 & 4113677.972 & 571896.481 \\
\hline BR13 & 37.16855239 & -116.18960947 & 4113674.506 & 571948.305 \\
\hline BR14 & 37.168639631 & -116.190240377 & 4113683.706 & 571892.208 \\
\hline BR15 & 37.168495428 & -116.189847337 & 4113668.007 & 571927.24 \\
\hline BR16 & 37.168579735 & -116.19004356 & 4113677.211 & 571909.739 \\
\hline BR17 & 37.168613689 & -116.189747561 & 4113681.202 & 571935.987 \\
\hline BR18 & 37.168623276 & -116.189915765 & 4113682.138 & 571921.044 \\
\hline Battery 1 & 37.168922699 & -116.18866208 & 4113716.307 & 572032.067 \\
\hline Battery 2 & 37.169005633 & -116.188668146 & 4113725.502 & 572031.449 \\
\hline
\end{tabular}

aUniversal Transverse Mercator (UTM) Zone 11, North American Datum (NAD) 1927 (U.S. Western) HAE = Height above ellipsoid 


\section{Appendix F}

\section{Use Restriction for CAU 552}




\section{CAU Use Restriction Information}

CAU Number/Description: CAU 552, Area 12 Muckpile and Ponds

Applicable CAS Number(s)/Description(s): CAS 12-23-05, Ponds

Contact (organization/project): $\underline{\text { NNSA/NSO Industrial Sites Project Manager }}$

Surveyed Area (UTM, Zone 11, NAD 27, meters):

Southwest Corner: $\mathrm{N}=4113679.689 ; \quad E=571846.151$

Southeast Corner: $N=4113651.911 ; \quad E=571956.183$

Northwest Corner: $\mathrm{N}=4113707.287 ; \quad \mathrm{E}=571861.946$

Northeast Corner: $\mathrm{N}=4113697.237 ; \quad \mathrm{E}=571958.191$

Survey Date: June 2005

Survey Method (GPS, etc): GPS

Site Monitoring Requirements: Inspection of fencing and postings

Required Frequency (quarterly, annually?): Annual

If Monitoring Has Started, Indicate last Completion Date: Not Applicable

\section{Use Restrictions}

The future use of any land related to this Corrective Action Unit (CAU), as described by the above surveyed location, is restricted from any DOE or Air Force activity that may alter or modify the containment control as approved by the state and identified in the CAU Closure Report or other CAU 552 documentation, unless appropriate concurrence is obtained in advance.

Comments: The upper pond may be released after the closure of the G-Tunnel muckpile. The use restriction implemented by this document may be revoked following a future corrective action that may eliminate the need for a use restriction at this site. See the Corrective Action Decision Document/Closure Report for additional information on the condition of the site and any monitoring and/or inspection requirements.

Submitted By:

Date:

cc with copy of survey map (paper and digital (.dgn) formats): CAU Files (2 copies) 


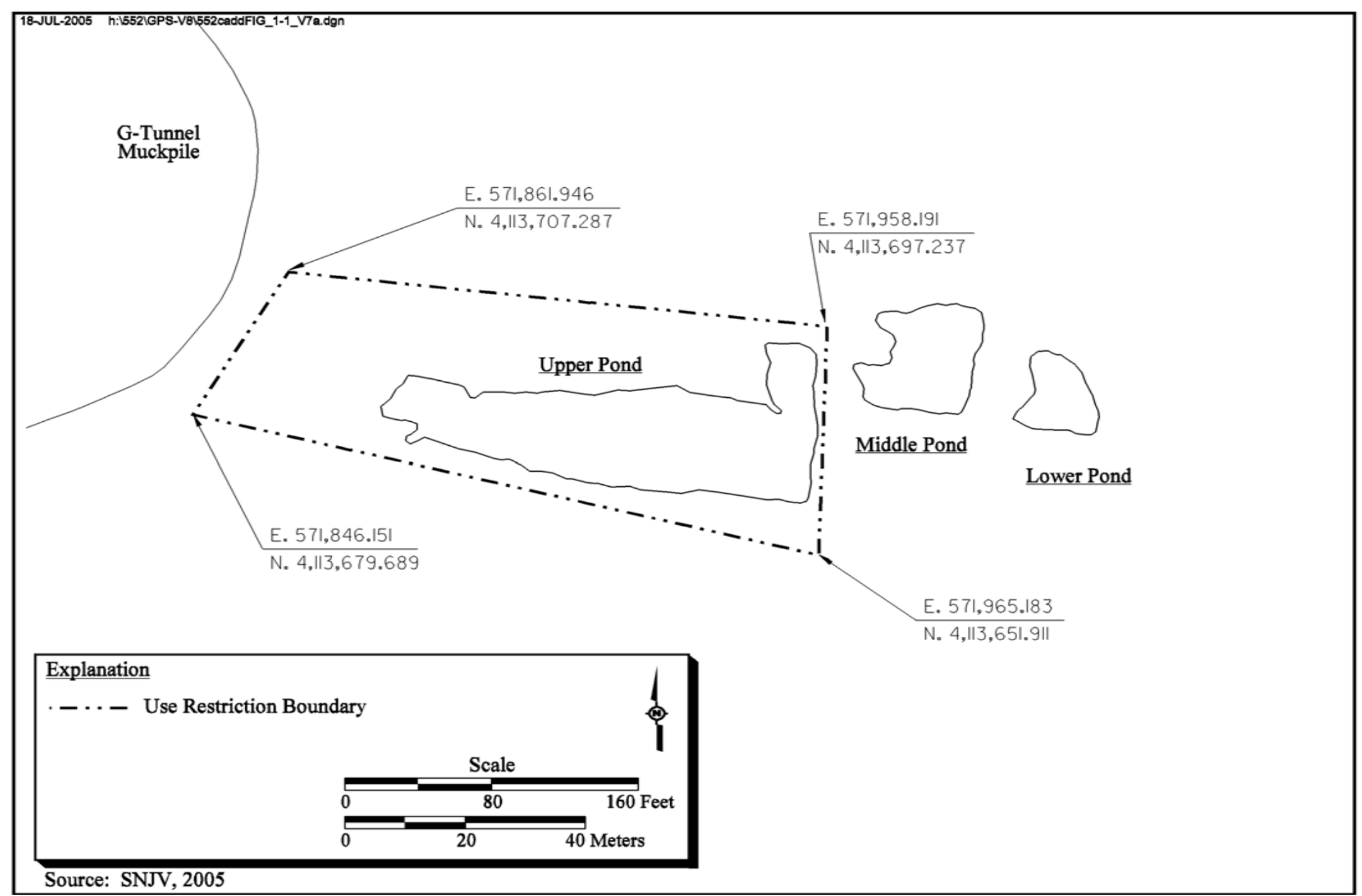

Figure F.1-1

CAU 552, Use Restriction Area 


\section{Library Distribution List}

\section{$\underline{\text { Copies }}$}

U.S. Department of Energy

1 (Uncontrolled)

National Nuclear Security Administration

Nevada Site Office

Technical Library

P.O. Box 98518, M/S 505

Las Vegas, NV 89193-8518

U.S. Department of Energy

1 (Uncontrolled, electronic copy)

Office of Scientific and Technical Information

P.O. Box 62

Oak Ridge, TN 37831-0062

Southern Nevada Public Reading Facility

2 (Uncontrolled, electronic copies)

c/o Nuclear Testing Archive

P.O. Box 98521, M/S 400

Las Vegas, NV 89193-8521

Manager, Northern Nevada FFACO

1 (Uncontrolled, electronic copy)

Public Reading Facility

c/o Nevada State Library \& Archives

100 N Stewart Street

Carson City, NV 89701-4285 